\title{
ريادة الشيعة لعلم الكلام
}

\section{م.د. ثائر عباسر هويدي النصراوي \\ جامعة الكوفة - كلية التر بـية - قسمم القرآن الكر يم والتر بية الإسلامية}

\begin{abstract}
||l||l||

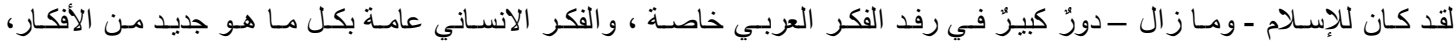

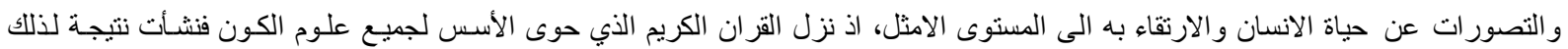

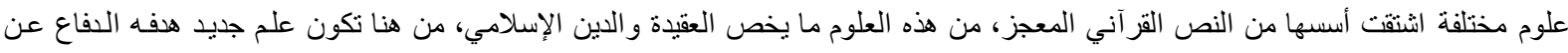

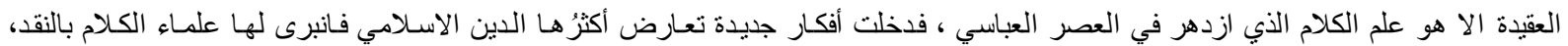
فردوا بعضها و ونقدوا بعضها الاخر و أخرجو ها بصورة تلائم الدين ، لذا جاء هذا الجهد العلىي ليتتاول في تمهيده معنى الكلام لغـة واصطلاحا

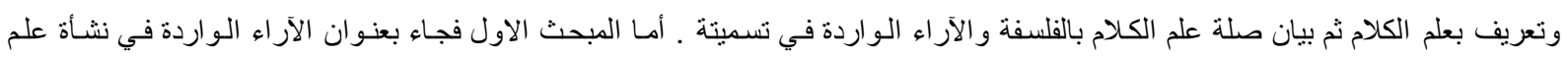
الكلام و العو امل المؤثرة فيها، و انقسم على قسمين الاول هو العو امل الداخليـة والخارجيـة لنشـأة علم الكـلام، والثناني هو العو امل غير المنظورة (الفردية) لنشأة علم الكلام. أما المبحث الثاني فهو ريادة الثيعة لعلم الكلام الاسلامي، و انقسم على قسمين الاول هو العوامل التي أدت الى تكوين

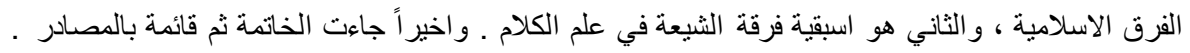

\section{Abstract}

Islam has been - and continues to be - a major role in supporting the Arab thought in particular and human thoughts in general, and vote for human life and elevate it to the optimum level, as the Holy Quran has revealed, which encompassed the foundations of all the universe sciences and they arose as a result of different sciences in which they are derived from the Quranic text. This is a new science whose purpose is to defend the doctrine, but it is the science of speech that flourished in the Abbasid period. It showed that new ideas were opposed to the Islamic religion. The scholars of speech criticize to them. They recited some of them and revised the rest. This scientific effort meant to address the meaning of speech in the language of the preface and idiomatically and the definition of the science of speech and statement related to theology and philosophy opinions contained in the name. The first section is titled as the opinions contained in the genesis of theology and the factors affecting them, and splitinto two parts the first is the internal and external factors of the emergence of speech science, and the second is the invisible factors (unique) of the origins of speech science. The second topic is the leadership of the Shiite Muslim theology, and was divided into two parts: the first one is the factors that led to the formation of the Islamic teams, and the second is the primacy of Shiites in the science of speech. Finally, the paper came with the conclusion and a list of sources.

\section{الإقدمهة}

لقد كان للإسلام - ومـاز ال - دورّكبيرٌ وعامل مؤثر في رفد الفكر العربي خاصـة ، و الفكر الانسـاني عامـة بكل مـا هو جديد من الأفكار ، و التصـورات عن حيـاة الانسـان والارتقاء بـه الـى المستوى الامثل بعد مـاكـان في حيز جهالـة وميدان ظلمـة ، اذ نـزل القـران الكريم الذي حـوى الأسـس لجميع علـوم الكون فنشـأت نتيجـة لذلك علوم مختلفـة ومعـارف متباينـة اشـتقت أسسـها مـن النص القراني المعجز، فضـلاً عن العوامـل الأخرى ، مـن جنس هذه العلـوم مـا يخص العقيدة و الدين الإسـلامي ، من هنـا تكون علم جديد هدفه الدفاع عن العقيدة الا هو علم الكـلام الذي ازدهر في العصر العباسـي ، و لاسيما في زمن المـأمون الذي اهتم بالترجمـة ، فدخلت أفكـار جديدة تعـارض أكثرُ هـا الدين الاسـلامي فـانبرى لهـا علمـاء الكلام بالنقد و التفنيد و التزييف ، فردوا بعضهـا و نقحوا بعضـها الاخر وأخرجوهـا بصـورة تلائم الدين ، لذا جـاء هذا الجهد العلمي ليتناول في تمهيده معنى الكلام لغة واصطلاحا وتعريف بعلم الكلام ثم بيـان صلة علم الكلام بالقلسفة وافتر اقه عنها و اخير ا الآراء الواردة في تسمية هذا العلم ـ أمـا المبحث الاول فجـاء بعنوان الآراء الـواردة في نشـأة علم الكـلام والعواملـ

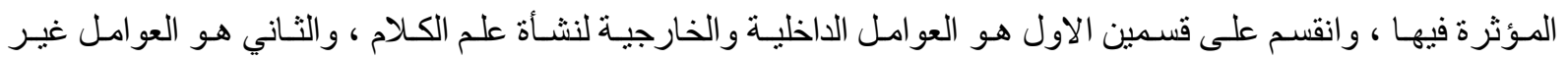


المنظورة ( الفرديـة ) لنشـأة علم الكـلام ـ أمـا المبحث الثناني فهو ريـادة الثيعة لعلم الكلام الاسـلامي ،و انقسم على قسمين

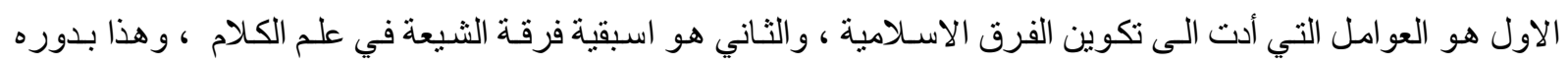

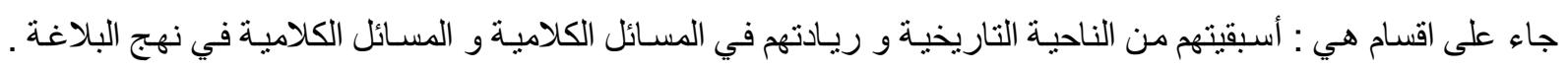

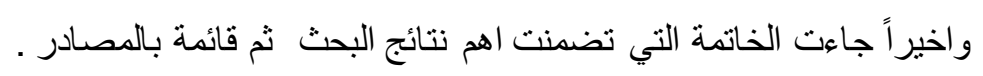

\section{التمهيس- علم الككلام : تعريفه ، تسسميته ،ملته بالفلسفة}

1 - الكلام لغة : إن معنى الكلام لغـة كمـا جـاء في مختار الصحاح هو ان :" ( الكلام ) اسم جنس يقع على القليل

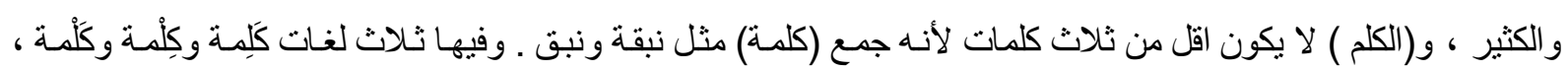

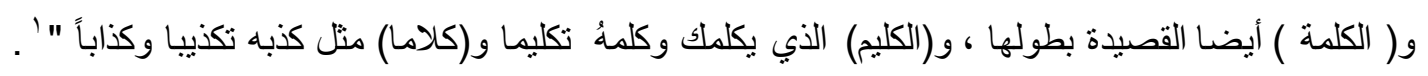

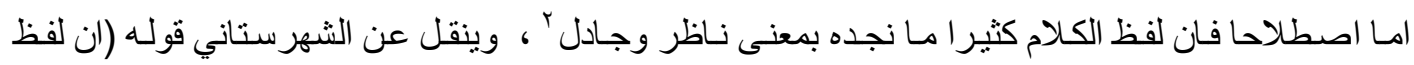

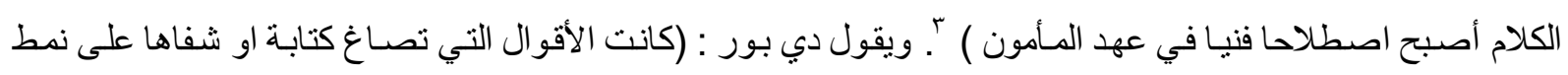
منطقي او جدلي تسـى عند العرب كلامـاً ، وكـان أصحاب هذه الأقو ال يسمون المتكلمـين ، ........ و وان لفظ المتكلمـين

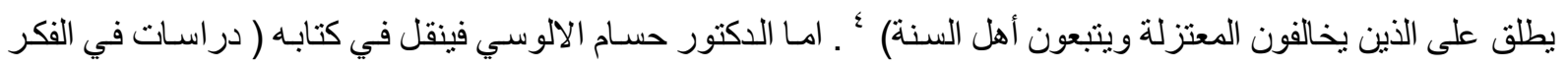

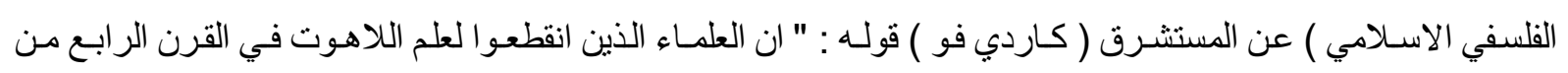

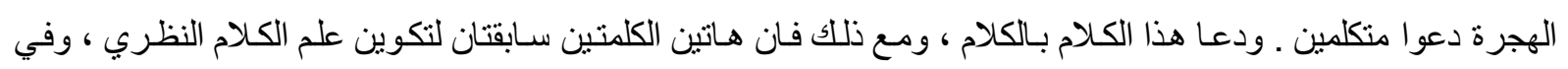

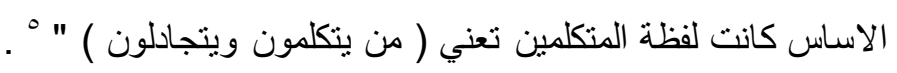

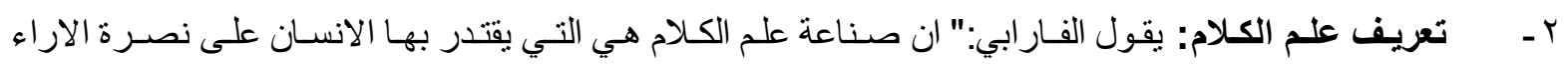

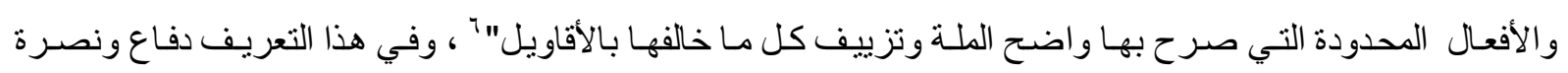
للعقائد الدينية بالكتاب و الحديث النبوي والقول بتزييف المخـالفين بالأقاويل والحجج ـ ويميز الفـار ابي بين علم الكلام و الفقهـ

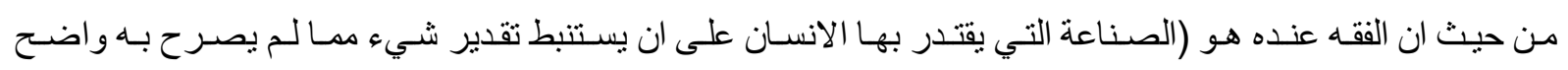

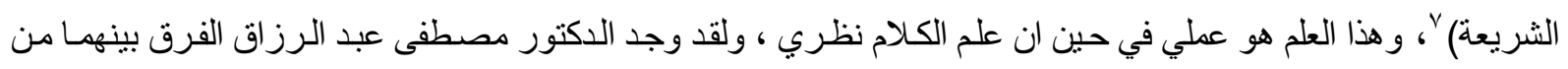

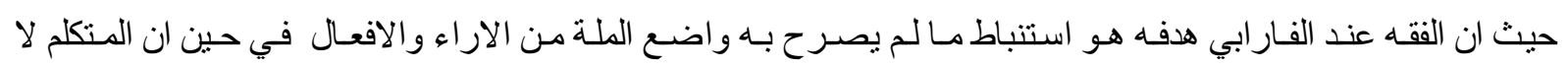

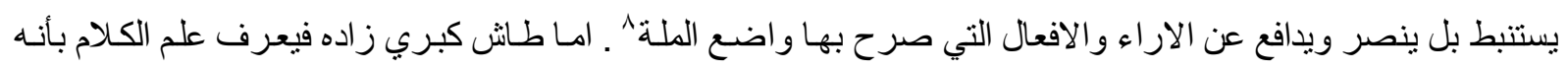

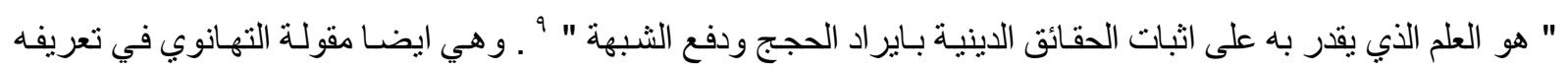

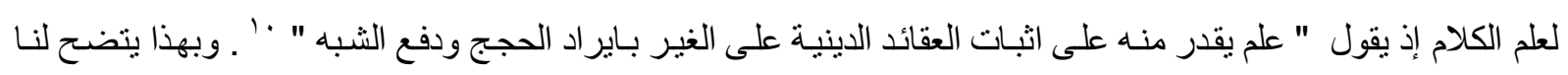

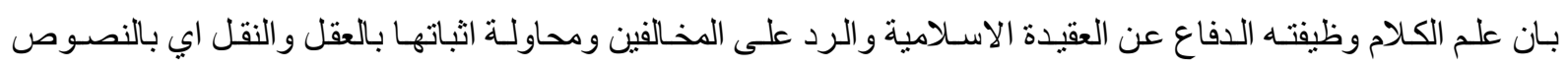

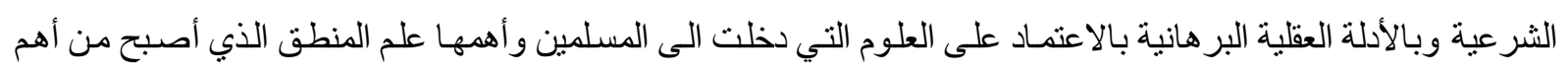
مقدمات العلوم الاسلامية وخصوصاً العقائد .

r - تجديد علم الكلام: نلاحظ ان علم الكلام بقي جامداً ولم يتجدد بحسب تجدد العلوم العصرية كما هي الحسال في

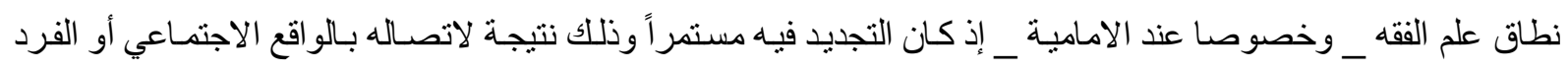

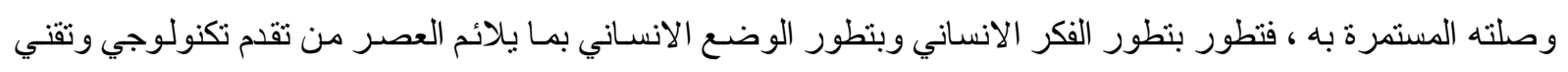

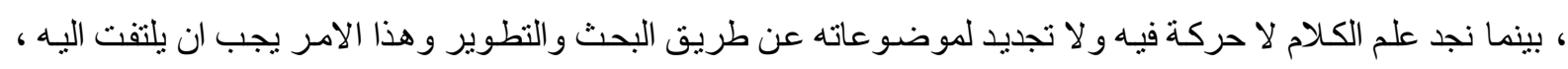
فاذا أردنا ان نطور علم الكلام فعلينا الرجوع الـى الواقع الاجتمـاعي وربطه بالعقيدة على اسـاس من التفكير المنطقي السليم 
، وذلك بالاعتمـاد الاسس العلمية التي ارسـاها القران الكريم إذ بنى عقائدنا عن طريق اشتنقاقها من الواقع المعـاث للامــة

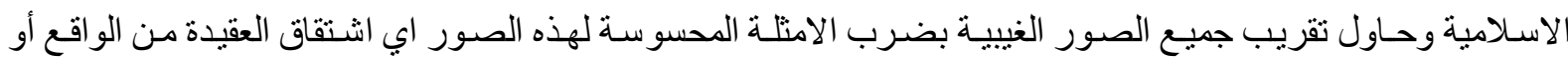

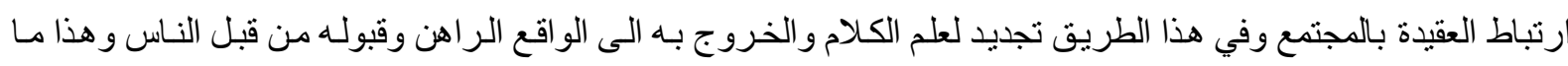

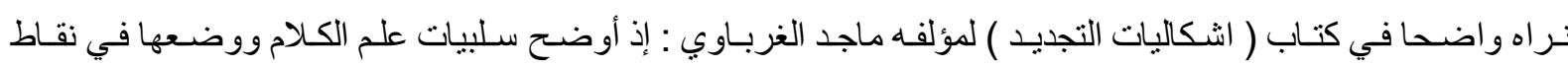
محدة هي : نراه

أ - زحف الجدل المحتدم حول المسـائل المطروحة ليقطع خيوط التواصل بين العقيدة والحياة الاجنماعية ، فعقيدة التوحيد

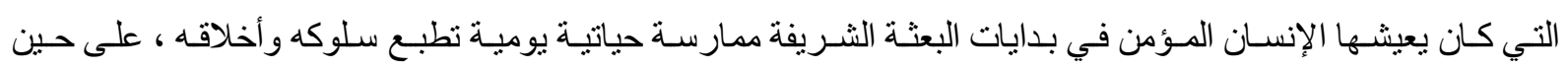

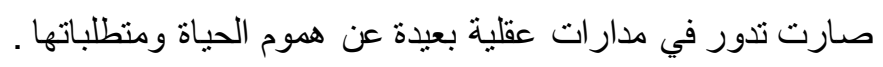

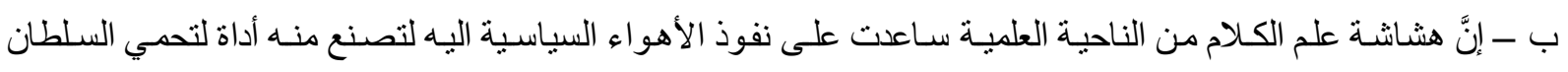

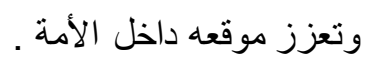

ج _ نشوء علم الكلام كان إيذاناً لتأسيس الفِرَق وتعميق الخلاف بين الدذاهب الإسلامية. . د _ أسقط الإنسان من معادلة المتكلمين وأهمل عنصر الحياة الاجتماعية الفاعل من دون أنْ يلتفت الى حاجاته وتطلعاته . أما المعالجات التي طرحها (ماجد الغربـاوي) لتجديد علم الكلام ، فكانت أوسع من اللمحة التي ذكرناهـا سـابقا

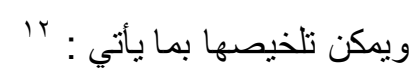
أ ـ إعـادة النظر بـالمفردات المطروحة للمناقشـة من ناحية العقيدة للفصل بين مـا هو ممكن ومـا هو ممتنع في نفسـه ، أمسا لقصور العقل البشري عن إدراكه أوعدم وجود أدلة كافية عليه.

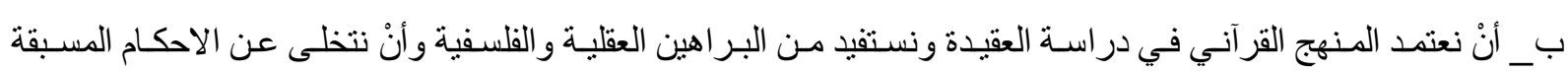
والآراء القطعية عند دراستها. جـ التخلي عن الجدل و التراشق بالألفاظ ومنهج التفكير لكل من لا يتفق معنا في العقيدة .

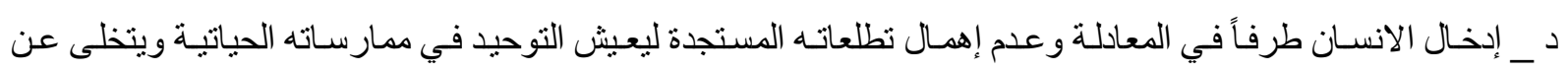

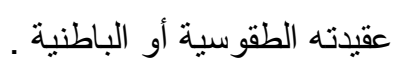
هـ ـ إبقاء العقيدة حية وفاعلة في النفوس عن طريق استشعار الانسـان بوجود الله تعـلى ، فليس ازمتنـا العقيديـة في اثبـات

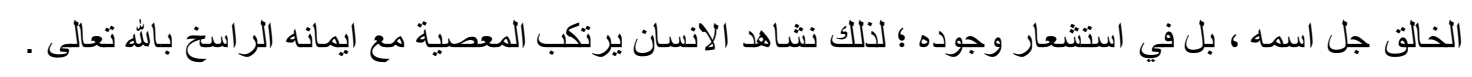
و _ تقديم اجو بـة كافيـة للتحديات التي تواجـه العقيدة و الفكر الاسـلاميين مـع مر اعـاة التطور ات المذهلـة على صـيد العلم

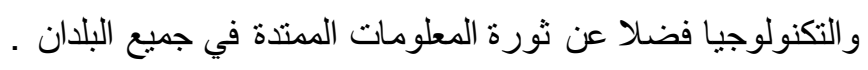
ز _ عدم الجمـود على فهم السـلف للعقيدة الإسـلامية فلكل زمـان ظرفـه ، و عليـه فيان فهمهم كـان يناسب حاجـاتهم الفكريـة و العقلية وقتذاك . ح__ أنْ نسمح بالاجتهاد وتبادل وجهات النظر في مفردات العقيدة كما هي الحال في الفقه وأصوله . 
في هذه النقاط الثرح الوافي لتجديد علم الكلام ويتضح لنـا أن علم الكلام عندنا يتبع خطوات علم الفقه وأصول فسوف يتجدد بالتأكيد وذللك لإن علم الكلام قابل للتجديد والتطوير كحال علم الفقه واصوله .

ونقطـة أخرى يمكن زيادتهـا على هذا الموضـوع ع ألا هـي دراسـة العقيدة مـن خـلال الظـواهر الاجتماعيـة ؛ أي

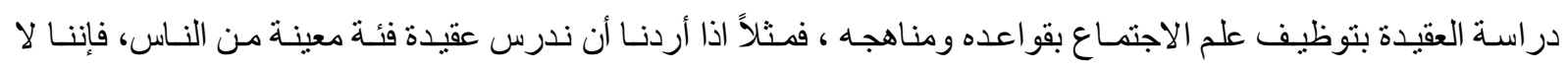

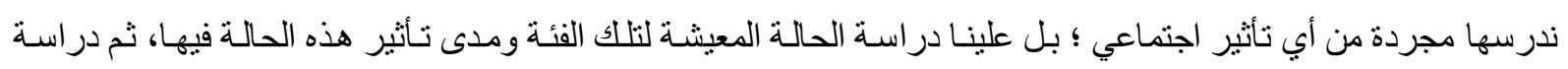
الظواهر السلبية في المجتمع وتأثير ها في رسوخ العقيدة أو عدم رسوخها ، ومـا إلى ذلك من الأمور الاجتماعية الأخرى ، وبهذه الطريقة بمكننا تجديد علم الكلام بالمحصلة .

\section{4}

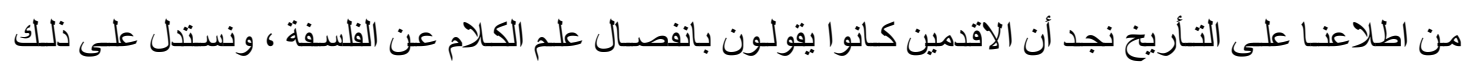

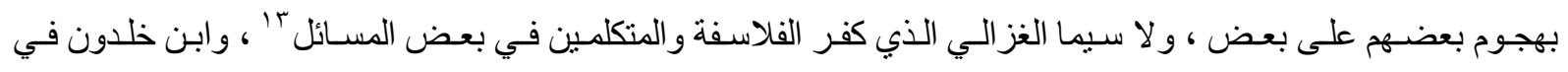

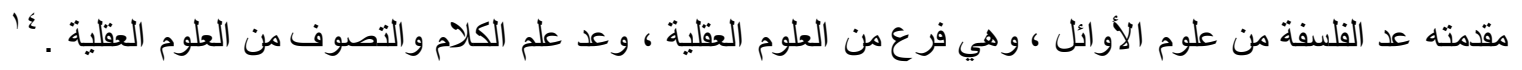
أمـا البـاحثون المحدثون فيقولون أن علم الكـلام جز ء من الفلسفة وهذا هو الر أي الصحيح ، إذ نجد الدكتور

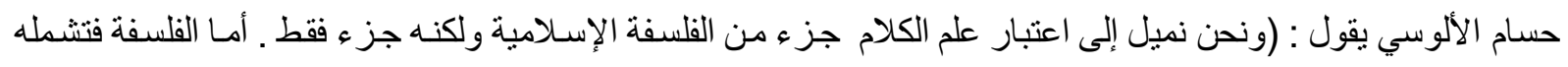

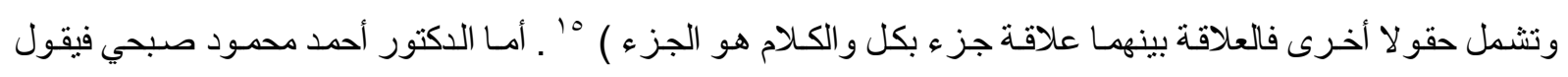

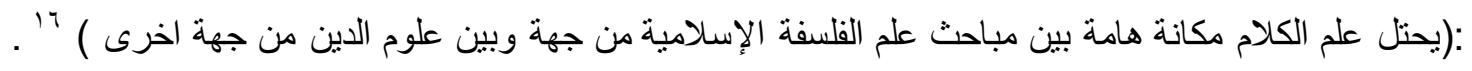
أما من جهة اختلاف علم الكلام عن الفلسفة فيمكن ملاحظته في المفاصل التالية V' :

أ _ من حيث الموضـوع : يمكن وضـع جميع المتكلمين في مدرسـة واحدة على أسـاس رأيهم في أصل العـالم وهو القول

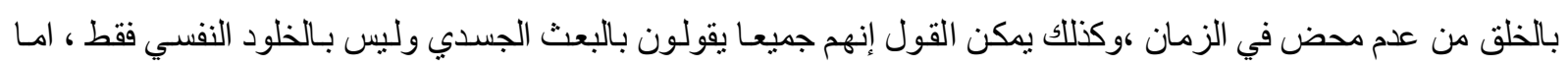

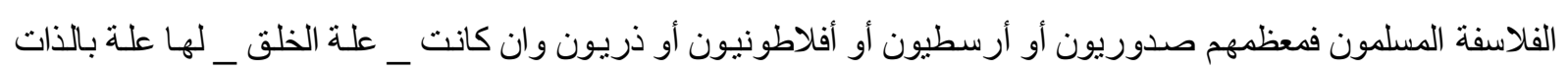

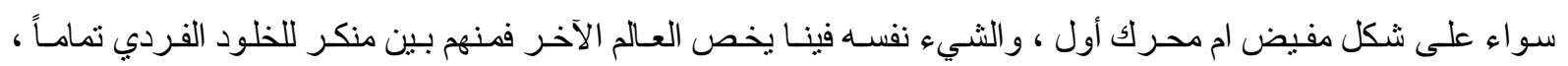
وقائل بالبعث بالروح أو النفس فقط .

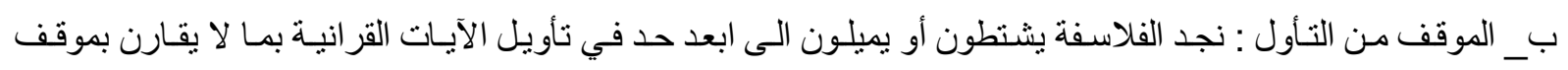

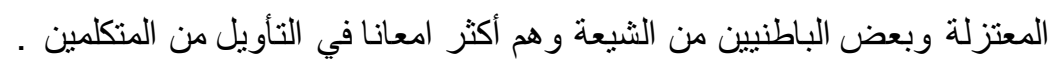

ج ـ الاعتمـاد على المصـادر اليونانيـة والدخيلـة : ان كل من يتنـاول كتابـاً لفيلسوف إسـلامي يجد الفرق في السياق بـين الموضوعات وكيفية تناولها فهي عند هو لاء تسير على نمط يونـاني أرسطي أو أفلاطوني وتستمد أسماءها وتسلسلها من

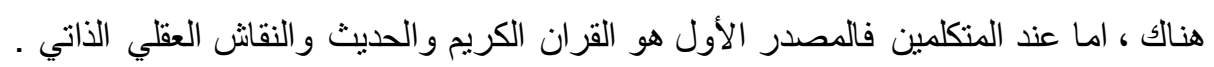
د ـ معنى الفلسفة عند الفريقين : لقد عرفنـا مـا يقصده المتكلمون من علم الكـلام أنه دفاع عن العقائد الايمانية بالادلة العقلية و الرد على الخصم ، في حين أن الفلسفة عند الفلاسفة هي البحث في الموجودات بمـا هي موجودة ، وهذا بعكس الفرق بين الموضوعات أو المنهج. لكننا نرى ان علم الكلام جزء من الفلسفة بدليل أن المتكلمين تنـاولو ا مسـائل إلهية في أكثر الأحيان ؛ ومن هذه

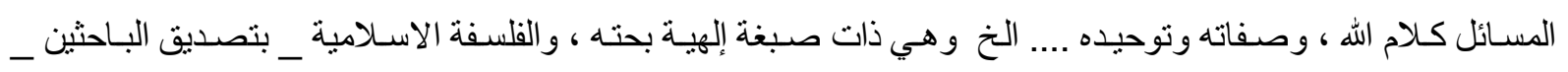


هي ذات صبغة إلهيـة أيضـاً وان مسـائلها الالهية هي اكثر مـن المسـائل الطبيعيـة والماديـة ؛ وبذلكك نستنتج أن علم الكـلام قريب جداً من الفلسفة بل هو جزء منها بالمآل .

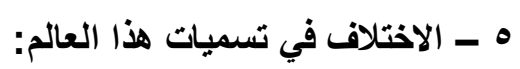

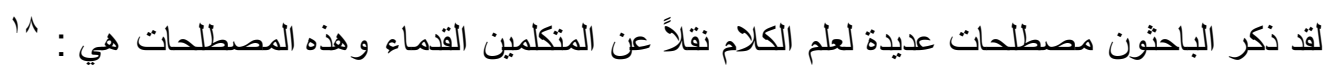
أ _ الفقه الأكبر : تمييزاً له من مباحث الفقه العلمية أو لأنه هو أصل العلم و لا يغيب عن البال أن معنى الفقه هو العلم . ب _ التوحيد و الصفات : لأن أهم مباحثه هي الله وصفاته فسمي الكل بأشرف أجزائه . جـ ـ أصول الدين:لأن مسائله مثل وجود الله ووحدانيته و المعاد ... الخ هي أساس الايمان و العقيدة الدينية. دـ _ علم النظر والاستدلال: لأنه يعتمد على الاستدلال العقلي وليس على النصوص و النقل فقط. اما تسميته بعلم الكلام فينقل الايجي أقو الا منباينة وهي : 19 ا - سمي الكلام لأنه بإزاء المنطق للفلاسفة .

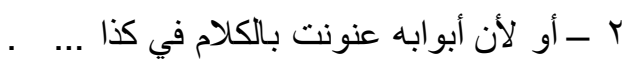
r - أو لأن مسألة الكلام أشهر أجزائه حتى كثر فيه التناحر والسفك فظلب عليه . ع - أو لأنه يورث قدرة على الكلام في الشرعيات مع الخصم . .

ويقول الدكتور أحمد محمود صبحي : ( ويبدوا ان أصح الأقوال في ذللك هو الراب الثالث ، فمسألة ( كلام الله )

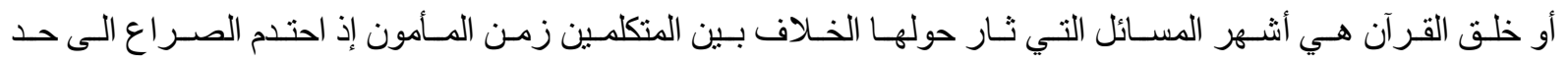
الاضطهاد وسفك الدماء بين المعتزلة والحنابلة حول مشكلة هل القران مخلوق أم غير مخلوق ؟ وهل كلام الله محثث أم

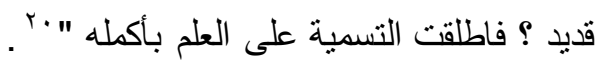

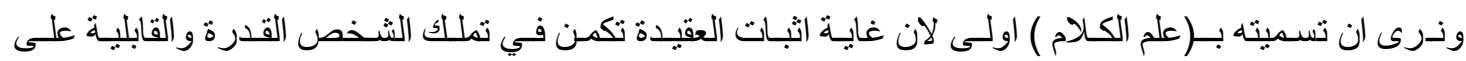
توظيف المنطلقات الصحيحة و المرتكزات الاسلوبية المنلى في بنيته الكلامية من اجل الوصول الى إقناع المنلقي إذ هو

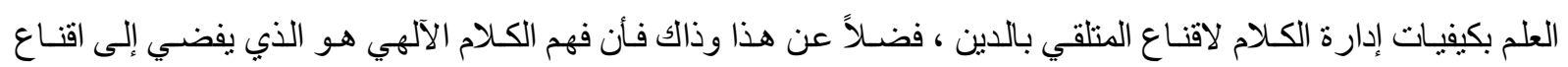

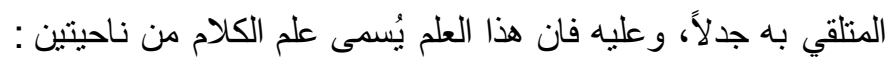
الأولى : فهم كلام الله و العلم بمعطياته ابتداءً . الثانية :العلم بكيفية الجدل وسبل ايصـال العقائد الدينية كلامـاً ،هن اجل ايصـاله الى المتلقي اقناعاً ، لذا نؤُثر تسميته بــ(علم الكلام ) على غير ها من المسميات ؛ وذلك لانها اشمل وادق في معالجة موضوعاته ومنطلقه وميدانه والغاية منه أداءً . المبمث الأول- الآراء الواردة في نشأة علم الكعلام والعواهل الموثرة فيها

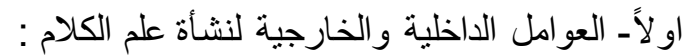

1 ـ الأسباب الداخلية : من مؤيدي هذا الرأي الدكتور عمر فروخ حيث إنـه يعزو نشوء علم الكـلام الى أسباب داخليـة

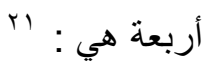


أـ الفضول العقلي : ويعني بـه سؤال المسلمين الرسول (صلى الله عليه والـه وسلم ) عن الأشياء التي ليس عنهـا

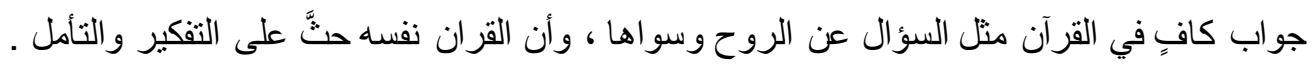

بـ ـ التشـد في المباديء :إن موقف النساس من العقائد مختلف فمثناً مسـالة الايمـان ومرتكب الكبيرة تختلف بـاختلاف

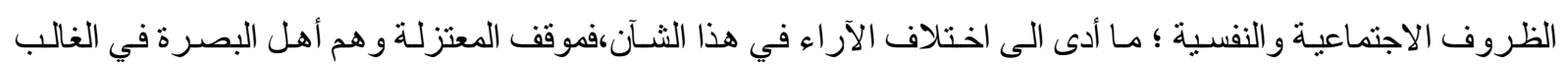
و الكوفة وبغداد من مقترف الكبيرة جاء مختلفا والخوارج فكانوا اكثر نشددا في المسألة وعدوا الإيمـان لا يتم إلا في (الكل) أي ان من ارتكب ذنبا كبيرًا أو صغيراً بطل إيمانه وكفر.

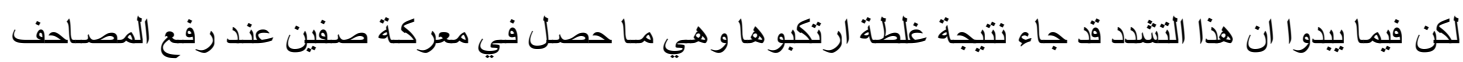

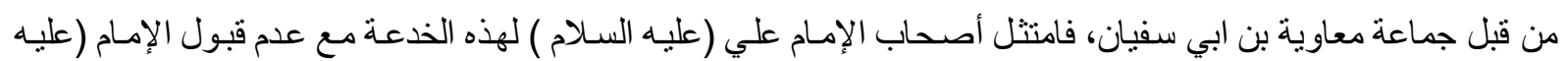

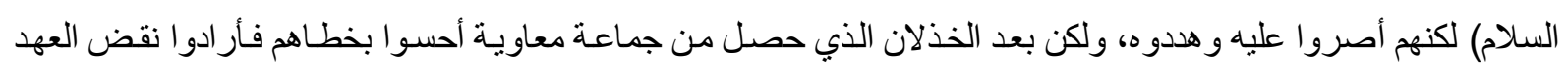

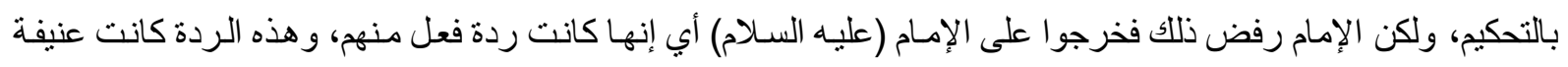
مما أدت بهم إلى رفض كل الآر اء الموجودة آنذاك واعتقدوا بمذهبهم فقط بل كفروا المذا هب الأخرى في مـا بعد، واحلوا قتلهم واستباحة أعراضهم وأمو الهم وما إلى ذلك. وقالوا إن الإيمان لا ينم إلا بالكل، فتشددوا في المبادئ نتيجة لذلك. أما المرجئة فكانوا أنصار بني أميسة في الثـام وكان هؤ لاء يعلمون أن بني أمية أخذوا الخلافة غصبا أو بـالقوة ،

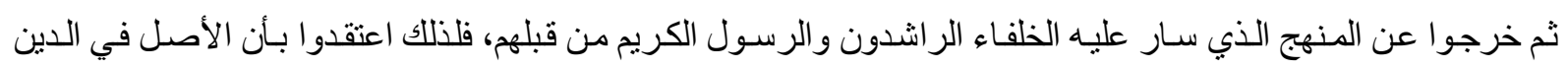

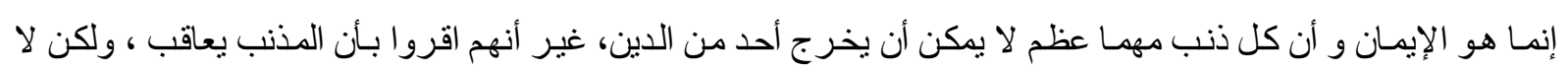

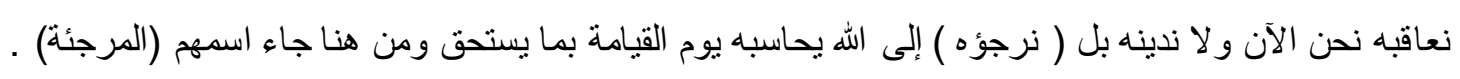

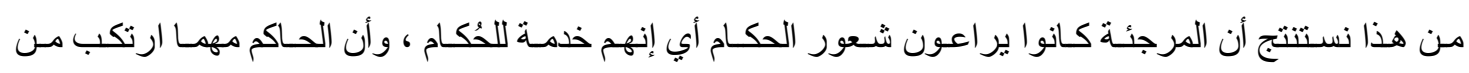

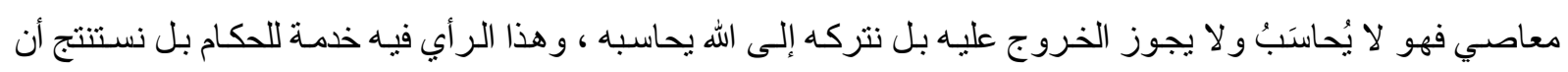

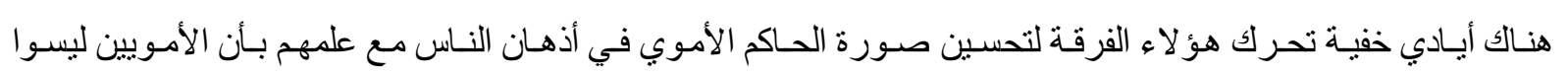
بأصحاب حق بالخلافة و الحكم.

ج - التفكير السياسي : وهنا يعزو نشوء علم الكلام إلى مسألة الخلافة ، ومـا إذا كان منصباً دنيويـا غرضـه إقامـة الأحكام

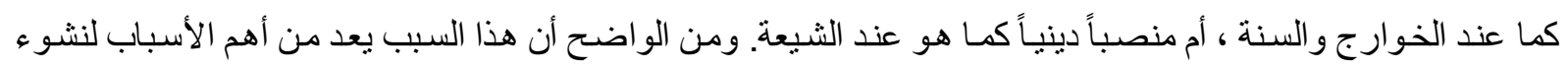

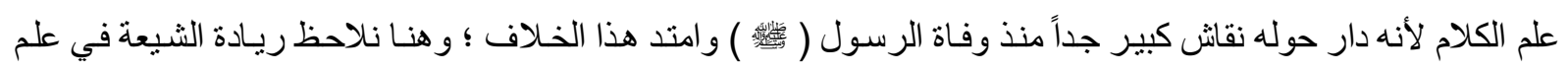
الكلام عن طريق تمكنهم من الجدل بموضو ع الإمامة ، بل إنه موضو عا أساسيا في المباحث الكلامية .

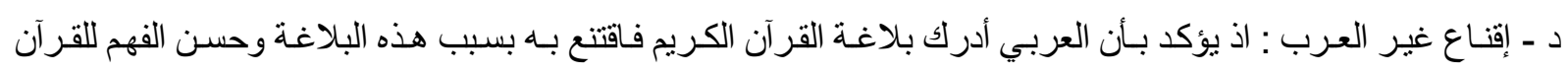

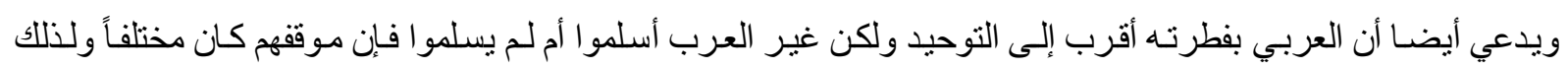

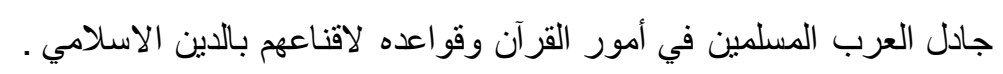

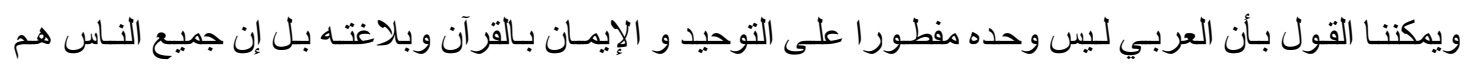

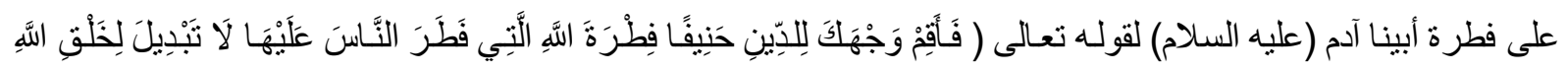

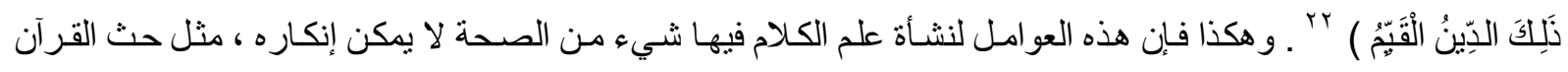

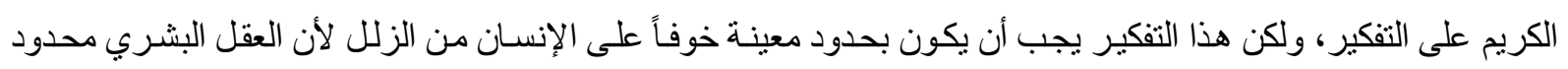


في قدر اته ومدركاته ، لذا كان من الواجب ان يظهر علم الكلام لئلا ينزلق الانسـان في متاهـات الـلا معقول ممـا يُفضي بـــ إلى الكفر .

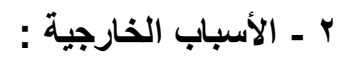

و ابرز من مَّتلَ هذا الرأي هو الدكتور علي سامي النشـار ؛ إذ يشير إلى أن علم الكلام يؤلف ( بحثناً فلسفياً يختلف

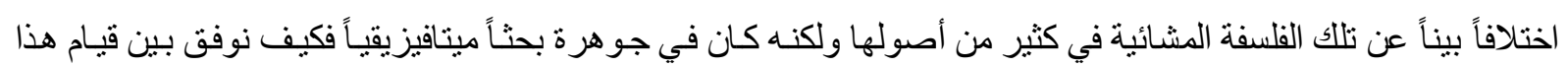

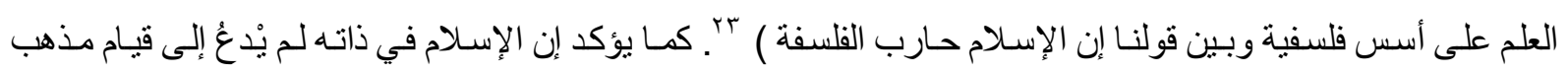

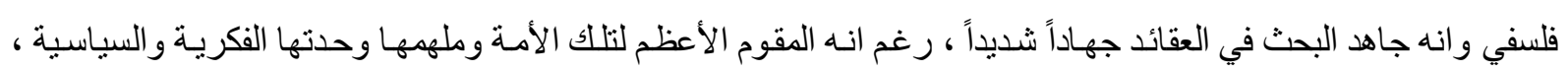

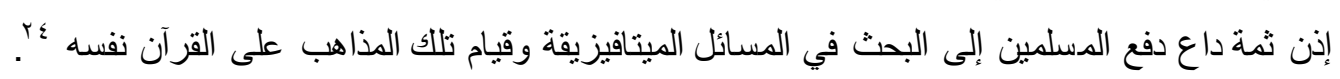
و هذه العو امل والأسباب ـ فيمـا يعتقد الدكتور النشـار - هي خارجية و لا تمت إلى الإسـلام بصلة ولليله مـا ذكر

$$
\begin{aligned}
& \text { ro : سابقاً وقد أوجز هذه العو امل بما يأني } \\
& 1 \text { - الأثر اليهودي . } \\
& \text { r - الأثر المسيحي . }
\end{aligned}
$$

ونؤثر ألا نتناول هذه العو امل بالتفصيل لأنها مذكورة بإسهاب في الكتب التي عينت بنشاة الفرق الإسلامية بـ.

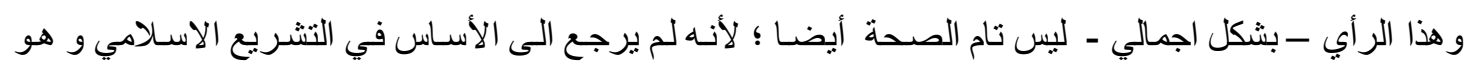

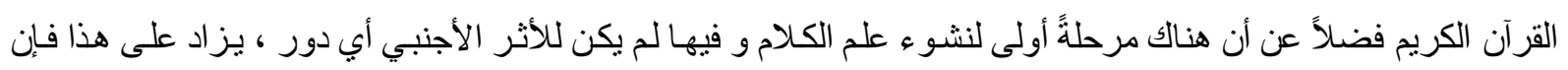

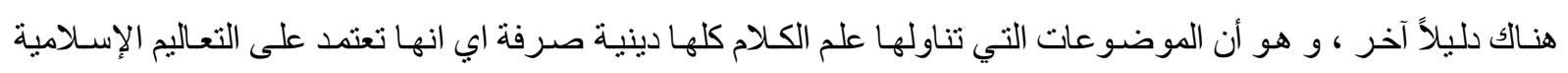

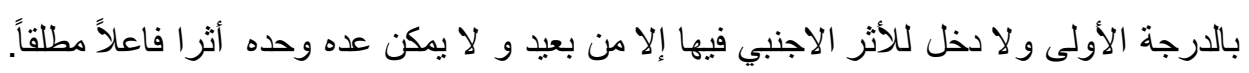

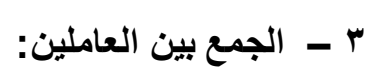

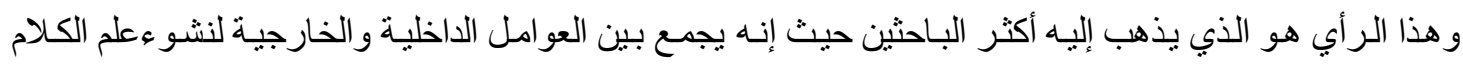

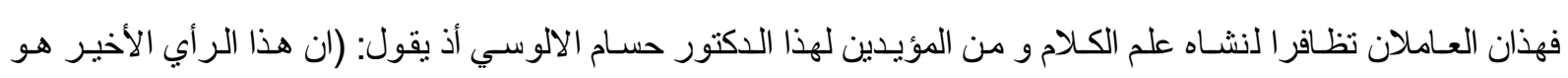

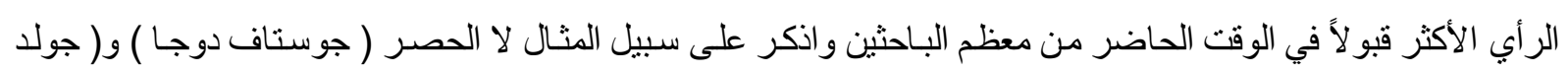

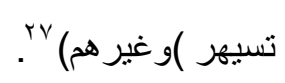
ونستنتج مما تقدم أنَّ هذا الرابي فيه الصواب ولكن هذا الجمع بين الر أيينِ لا يؤخذ على علاته بل لابد من تقسيم

$$
\text { مر احل نشوء علم الكلام على مرحلتين هما: }
$$

مرحله الايمـان القلبي و مرحله التفكير العقلي، فقضلاً عن الايمـان يرد الجدل في المرحلة الاولى إذ كـان يدور

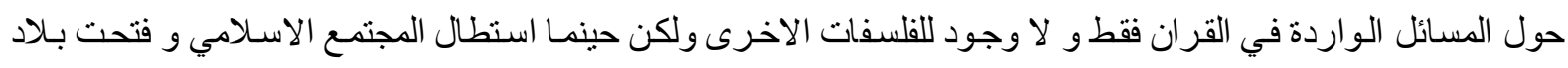

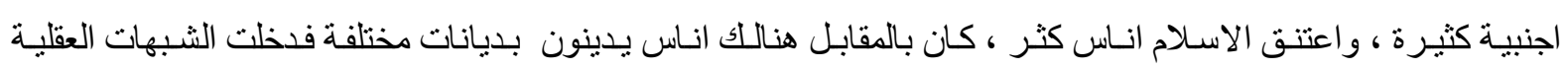

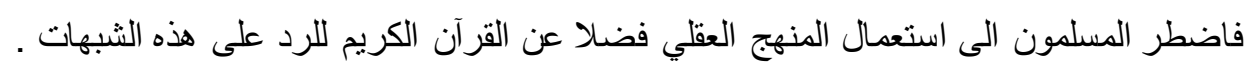


و على هذا نقول ان لنشو ع علم الكلام مرحلتين مرحله اولى كان لعلم الكلام فيها مسـائل داخلية فقط وكان القرآن

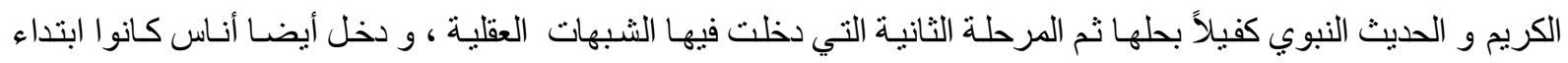

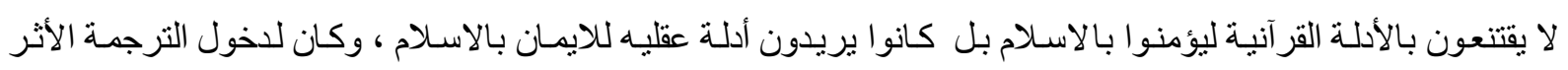

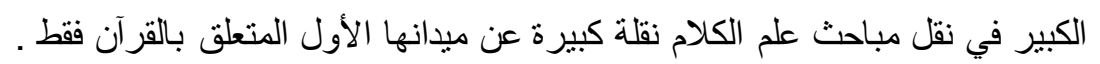
ثانياً - العوامل غير المنظورة ( الفردية ) لنشأة علم الكلام :

هناك العديد من العوامل التي أثرت في نشوء علم الكلام لكن هذه العوامل غير ملتفت إليها أو غير منظور إلى إليها،

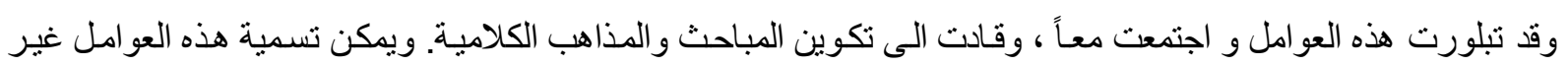

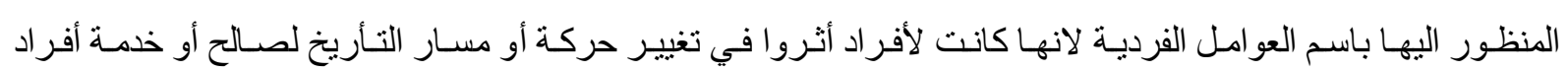
آخرين. وهذه العوامل بمكن اجمالها بما بأتي : أ ـ السلطة الحاكمـة وتأثثر هـا في المذاهب والفرق بحيث تـدعم الفرقة التي يكون لآر ائها اثر مهم في المجتمع ، وتدعم

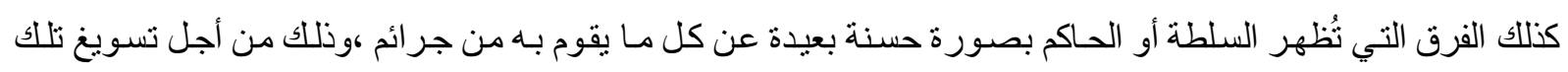

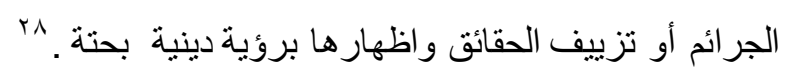
ب ـ قيام بعض الاشخاص بوضـع الأحاديث الملفقة عن الرسـول (صلى الله عليه والـه و سلم) كمـا حدث نلك في زمن

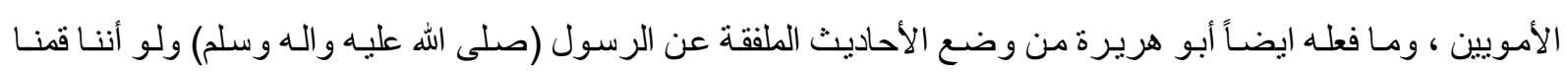

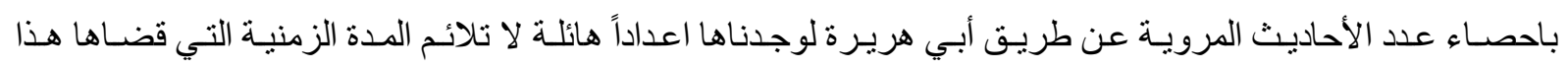

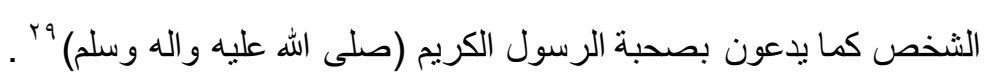

جـ التقرب النسبي للرسول (صلى الله عليه واله وسلم) ، او التقرب اليه عن طريق المذهب ، أي إنهم يتبعون سنة الرسول

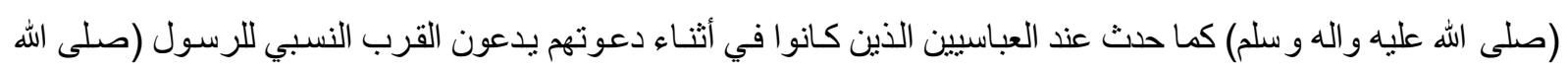

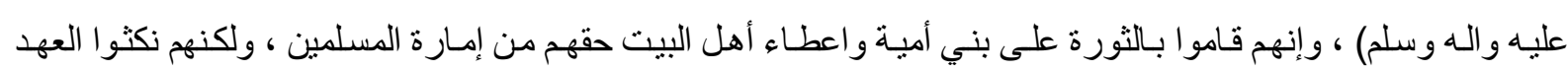

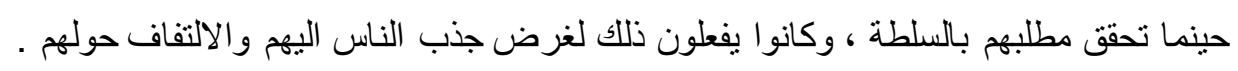

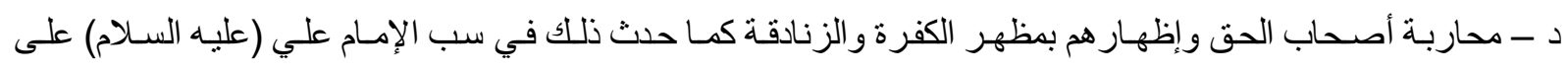

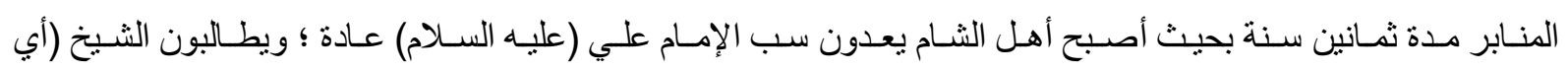

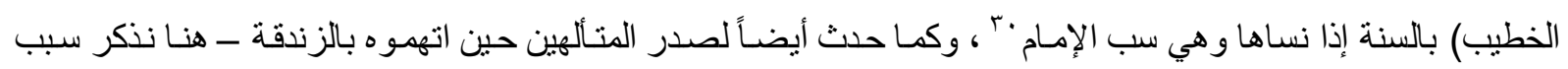

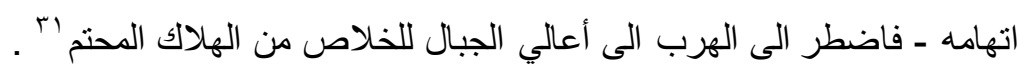
هـ - أثر المستشارين من يهود ومسيح الذين حساولوا بجهدهم إبعاد الحكام عن إنصـاف النـاس ، وحاولوا تحريف الدين بمـا

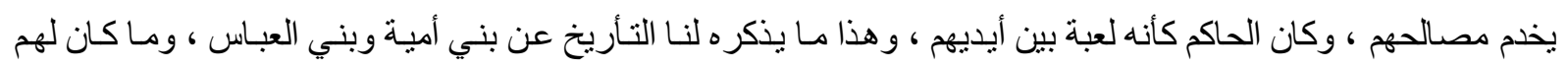

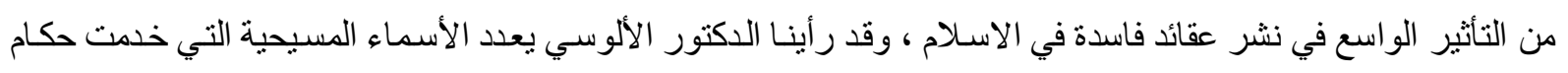
بني أمية ومنهم (يوحنا الدمشقي) الذي كان و الده (سرجيوس) مستشـار آل لدى معاوية و وعبد الملك وكذللك ممن خدم الأمويين

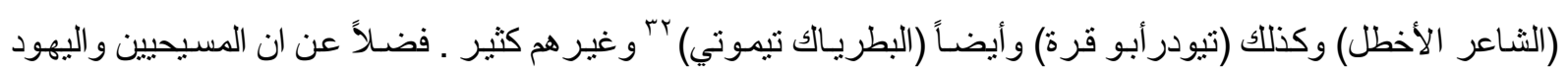

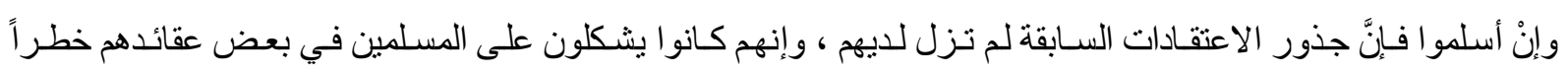
كبيراً، فكان ذلك من أسباب نشو ع علم الكلام للافاع عن العقائد ضد هذه الثببه اليهودية والمسيحية . 
و ـ الدو افع الثخصية والرغبات الذاتيـة لأصحاب المذاهب أنفسهم حيث إنهم كانو ايتقربون الى السلطان للفوز بالثـهرة

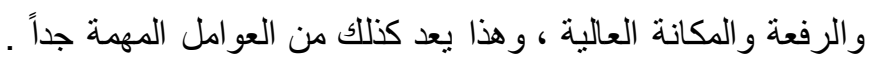

ز - محاولة ضرب الخصم بايقاع التناز ع والتناحر بين المذهب واستغلال مشـاعر الناس في محساولتهم التقرب الى السنة

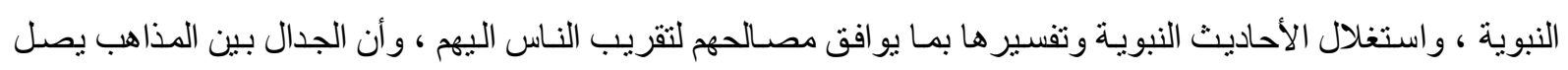

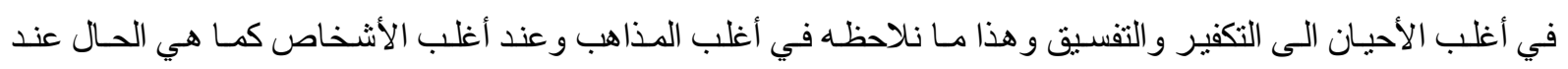

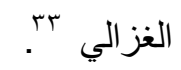

ح - استغلال فتـاوى الفقهاء في تكفير الفلاسفة وأهل الكـلام لكي يحققوا مـا يسعون اليسه وهذا مـا حدث للأشعري الذي استغل هذه الناحية فخرج عن المعتزلة لتكوين مذهب مستقل به.

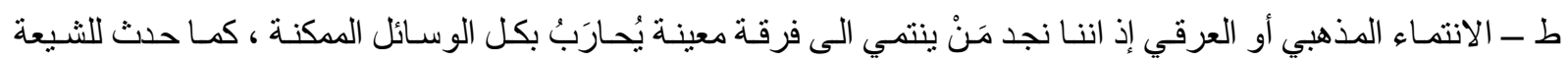

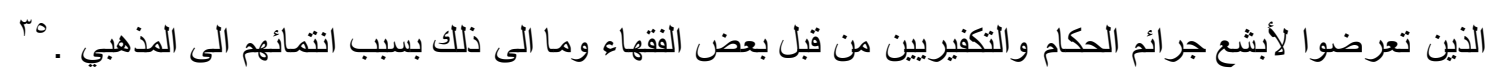
ي ـ محاولة بعضهم تغييب الموضدوعات الاساسية التي دار عليهـا النقاش الكلامي وجعلهـا من المسـائل الثانويـة في هذا

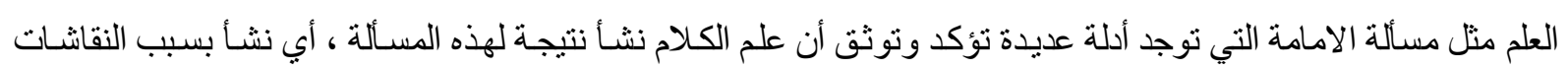

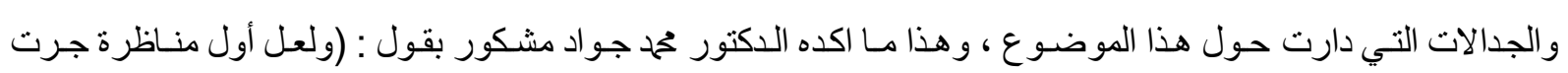

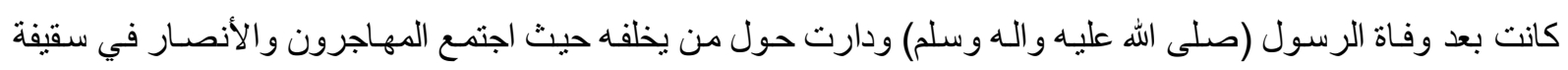

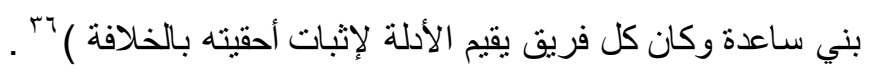

و يقول أيضا : (وتكررت مثل هذه المناظرات حول موضوع الأولويـة في الخلافة بين العباس بن عبد المطلب

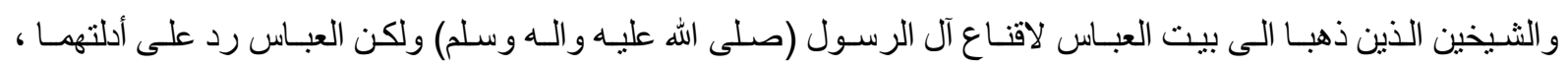

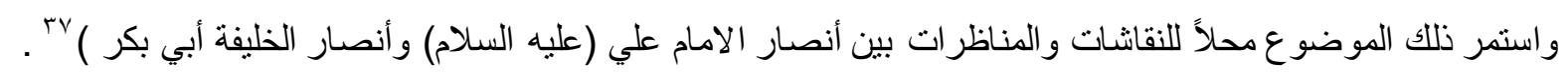
ك - إن لعصر الترجمة أثراً مهماً في نشوء علم الكلام ، وما قامت بـه المدارس في ذلك العصر من ترجمة الكتب الفلسفية

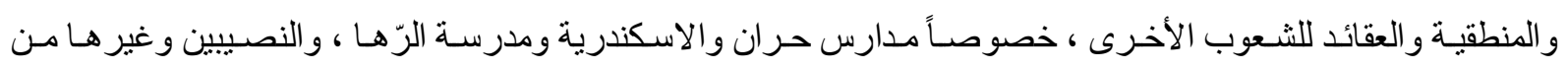

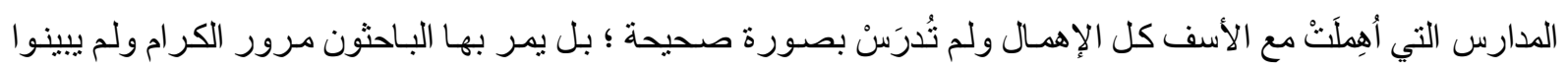

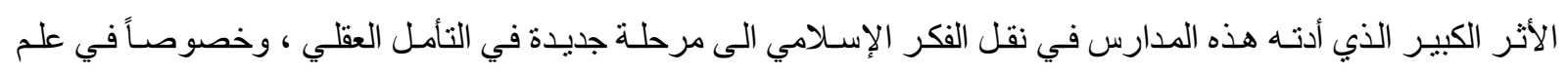

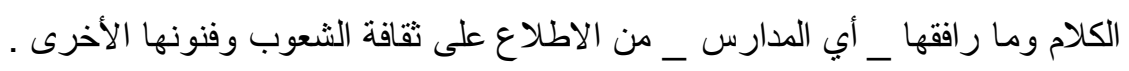

و هذه نقاط مهمة جداً حـاول الباحثون عدم إير ادها لأنهم لم يستنطقوا التاريخ بصورة صحيحة ، و عليه فإنتـا نأمل أن نصل الى نتيجة في دراسة تأريخ الفرق الإسلامية بصورة موضوعية بعيدة عن التوجهات الأبديولوجية والأهواء الذاتية والمذهبية .

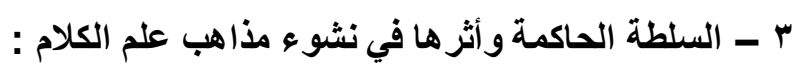

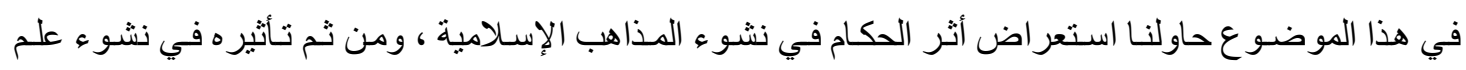

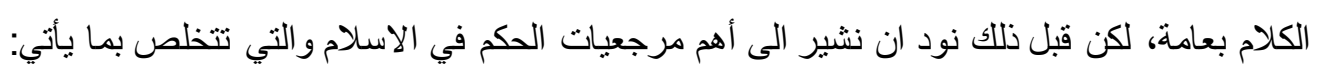
أ ـ العقل : كمـا ورد عند الفلاسفة كالفـار ابي في المدينـة الفاضـلة ^بّ ودور الحـاكم أو الـرئيس فيها وصـفات رئيس هذهـ المدينة وغيره من الفلاسفة وَ إذ جطوا للرئيس حكمة عقلية يسنطيع بها تصريف أمور الحكم وأمور العامة . 
ب ـ النصوص القر آنية : و هي ما ورد في القران الكريم من حث الحـاكم على حفظ الرعية وأداء الأمانة بصورة صحيحة

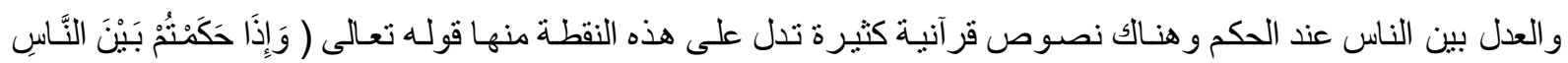

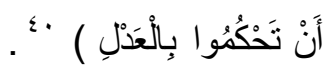
جـ ـ الأحاديث النبويـة : و هي النصـوص الواردة عن الرسول (صلى الله عليه و الـه وسلم) وفيهـا أيضـاً نصوص أصسول

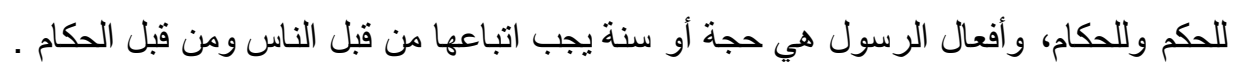
د - السيرة و الحوادث التاريخية : و هنا نجد دور الامر اء و الحكام والخلفاء وكيفية قيادتهم للأمـة اعتمـاداً على القران الكريم

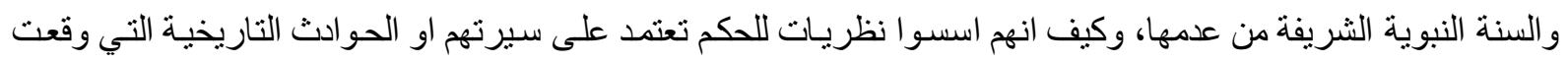

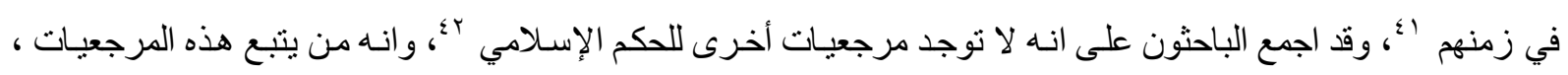

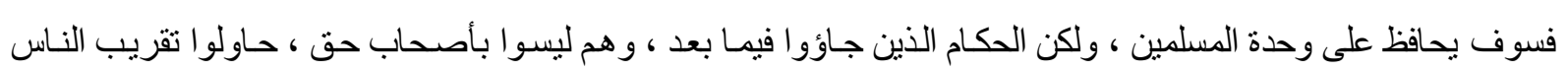

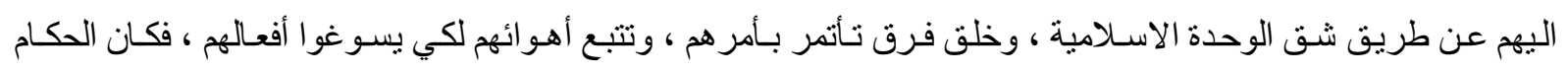

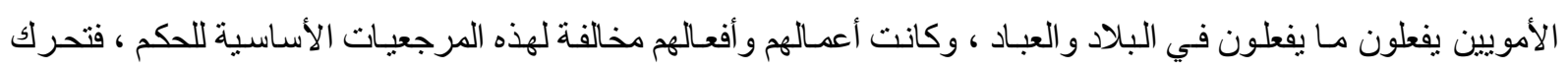

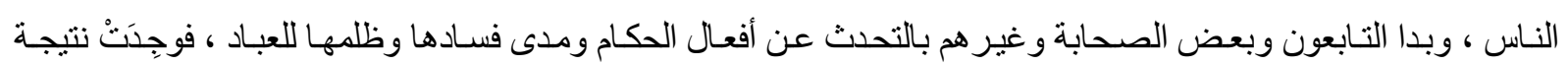

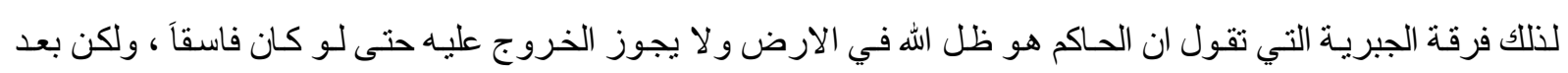

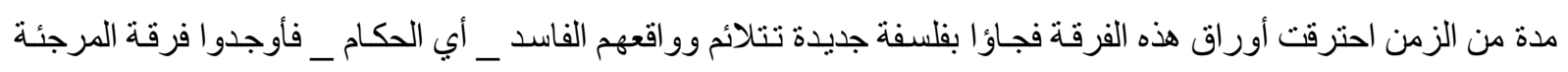

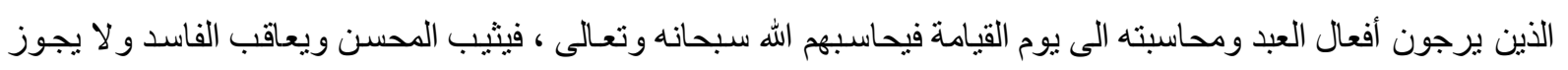

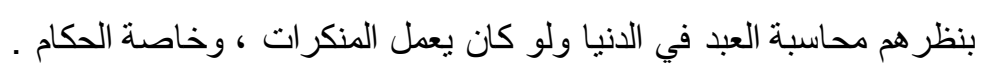

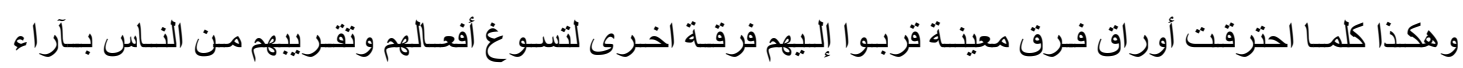

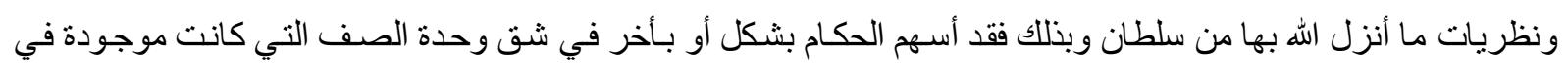

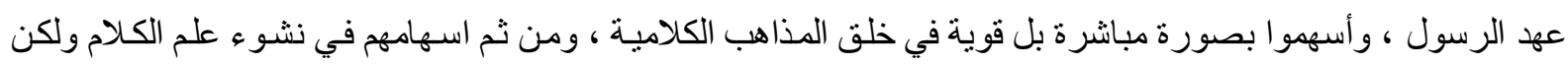

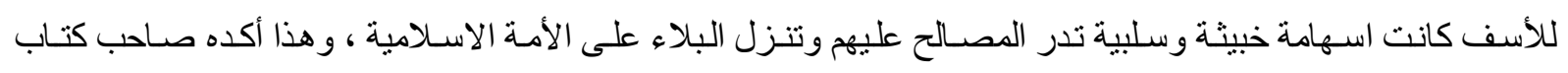
(موسوعة الفرق الاسـلامية) بقوله ( ويعتبر العصر العباسي أيضـاً عصر كثرة الفرق الاسـلامية المحسوبة على الاسـلام

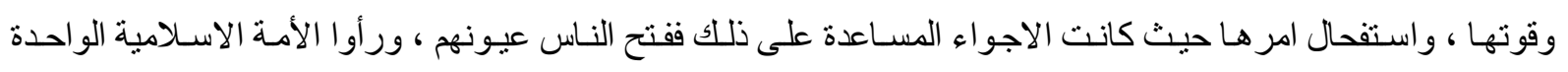

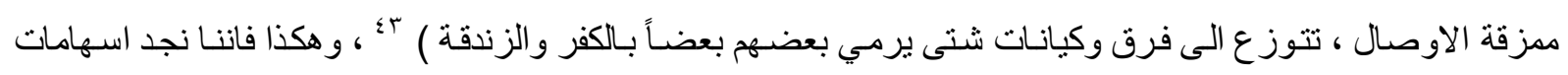

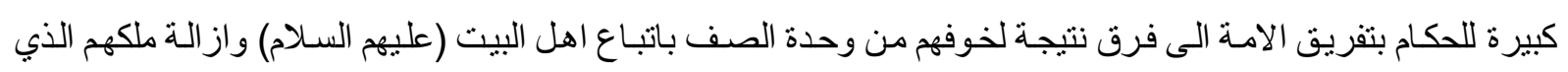

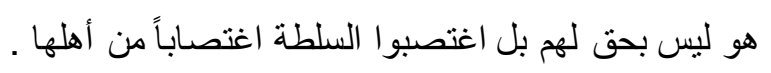
ونستخلص بـأن أهم العوامل التي أنت الى ظهور المذاهب الاسـلامية هو الابتعـاد عن خط محمد (صلى الله عليه واله وسلم) وأهل بيته (عليهم السلام) وهذا ما سنتناوله بالتقصيل في نشأة الفرق الاسلامية في المبحث التالي .

\section{المبمث الثانب- ريادة الشيعة لعلم الككلام الاسلامي}

اولاً : العوامل التي أدت الى تكوين الفرق الاسلامية :

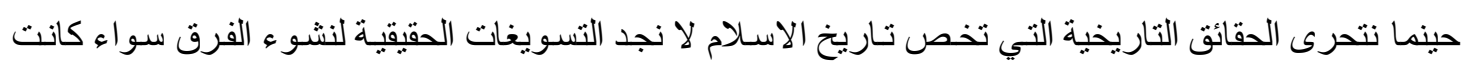
كلامية أم فقهية أو غير ذللك، وو علة نلك هي ان الرسول (صلى الله عليه والهه وسلم) حينما فـارق الحياة الدنيا ترك الامسام

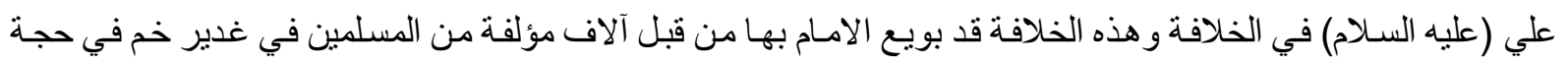


الوداع للرسول (صلى الله عليه والهه وسلم) ؛ لكن الذي يؤسف عليه هو أن الأهو اء والأغراض الشخصية وحب الظهور

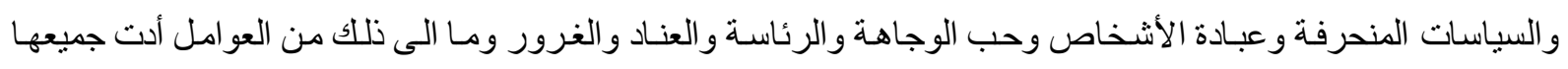

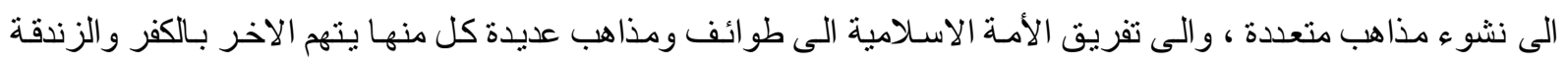
من دون حجة عقلية أو دليل واضح ويضل موضوع تعدد الفرق مثنار جدل ونقاش واسع الى أن يأذن الله بظهور من يوحد هذه الأمة العريقة .

وان بدايات التقرقة ترجع الى زمن وفاة الرسول (صلى الله عليه و الـه وسلم) و هي مرحلة جنينية _كما يقول

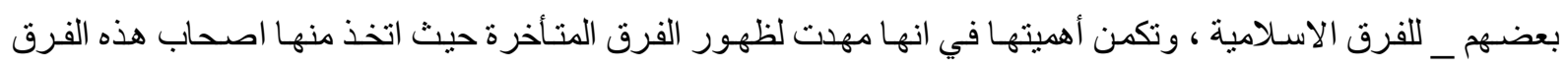

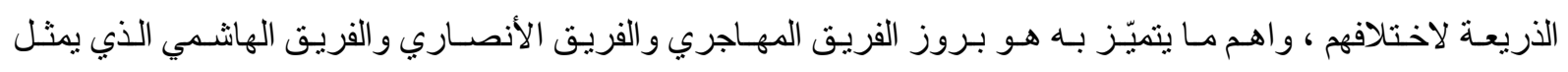
الامتداد الطبيعي للنبوة:؛

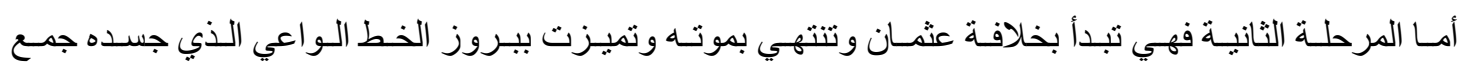

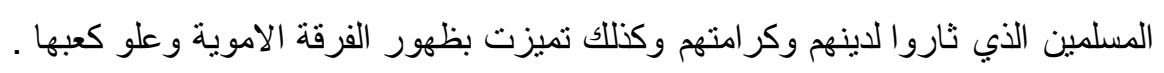

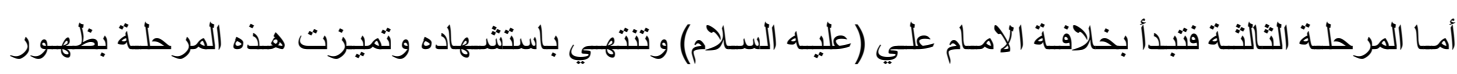

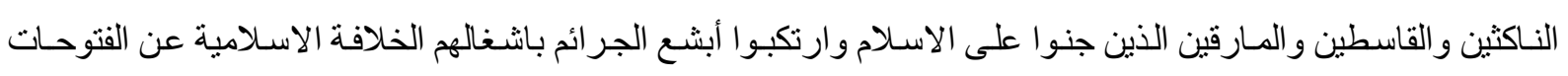

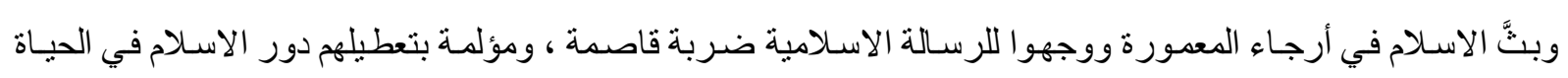

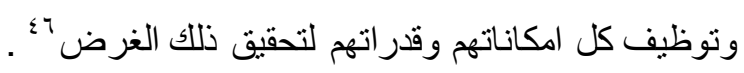

ثم جاءت بعد ذلك مرحلة الحكم الأموي وظهور فرق الخوارج بوصفها فرقة اسلامية لها عقائدها وليست كيانـاً

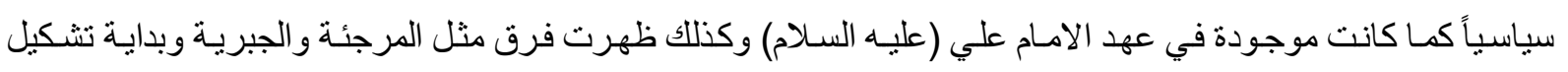

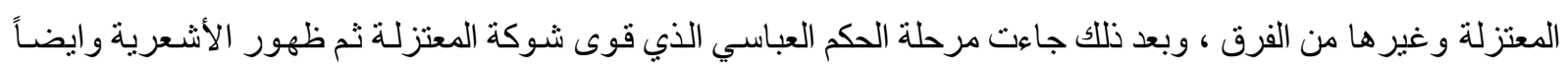

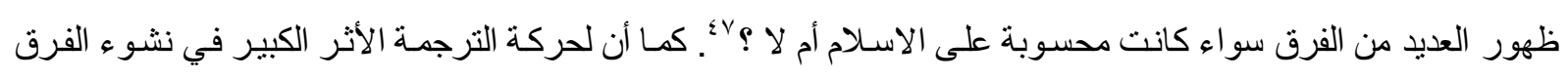

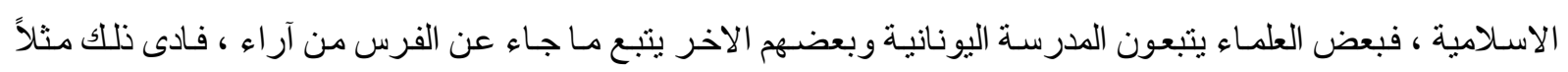

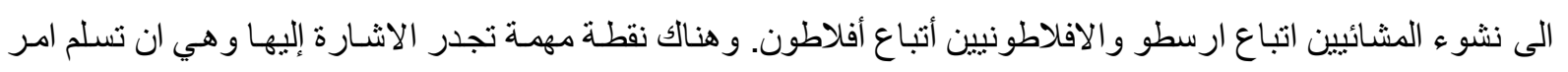

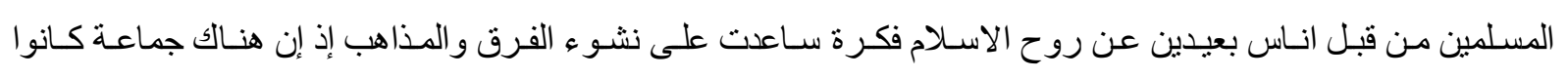

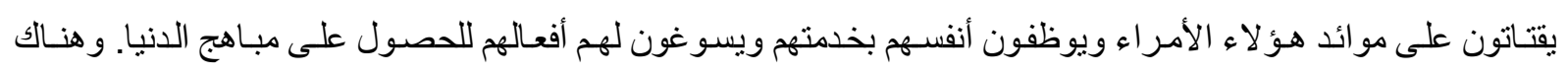

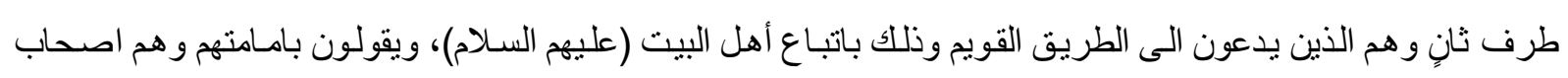

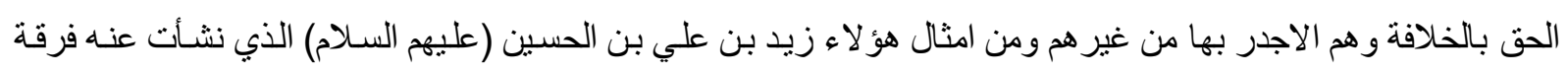

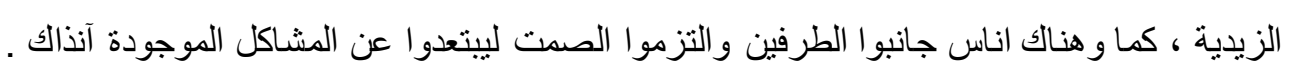

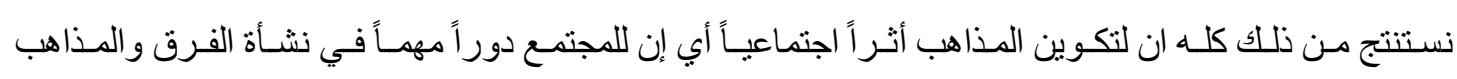

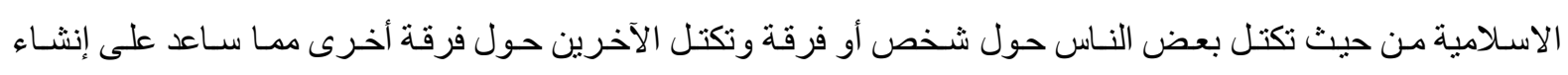

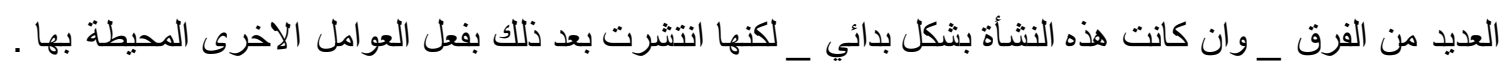
ثانياً : اسبقية فرقة الثيعة في علم الكلام :

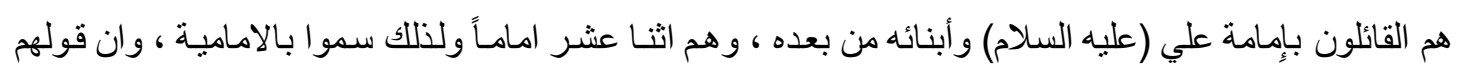

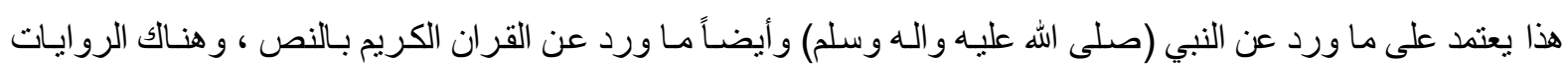


العديدة التي تثبت ذلك مما افاض به كتاب الثيعة و علماؤهم ـ وسيجري تقسيم هذا المبحث الى جملة فقرات تنظـافر لبيان ريادة الامامية في هذا المجال وهي على النحو الاتي : أ_ أسبقيتهم من الناحية التاريخية :

هنالك العديد مـن الروايـات التي تدل على انه لا يوجد في الاسـلام فرقـة سـوى هذه الفرقة بسبب ان أئسـة هذه

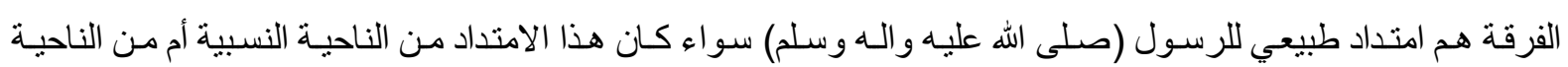

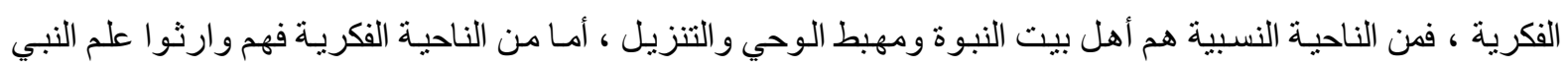

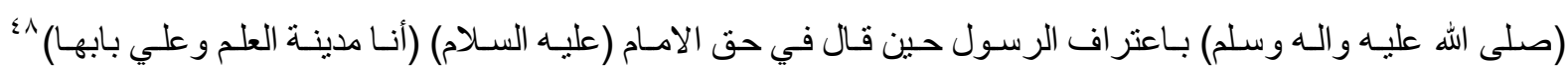

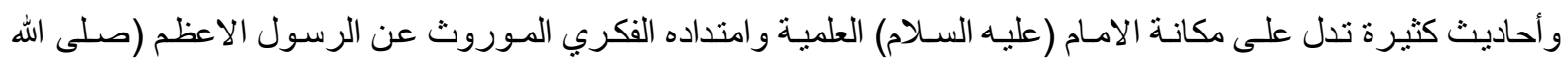

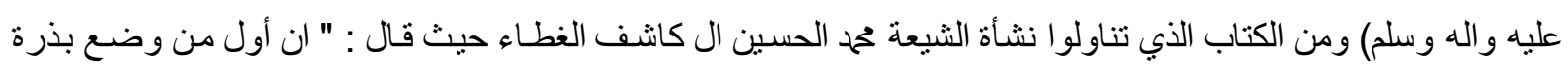

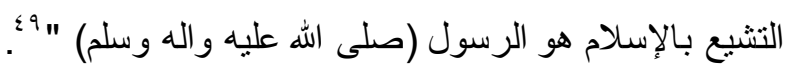

ويعني أنَّ بذرة التشيع وضعت مع بذرة الاسلام جنباً الى جنب و الشـاهد على نلك هو احاديث المصطفى (صلى

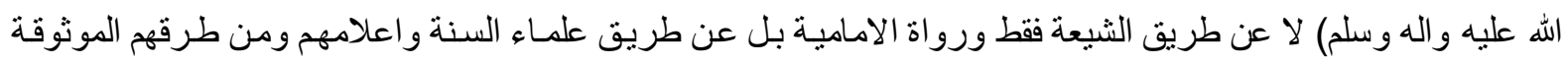

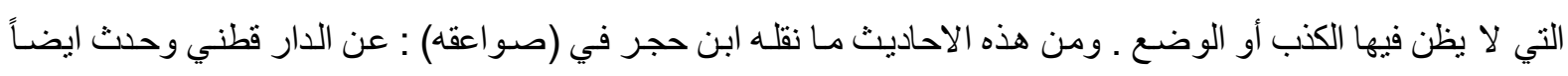

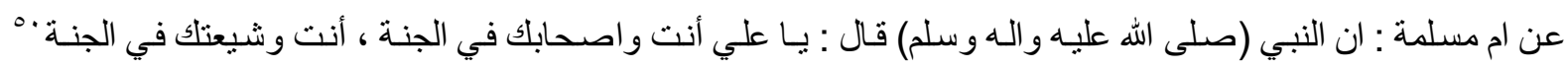
وايضاً رواية عن ابن الاثير : مـا نصسه عن مـادة (قـح) : إذ قـال الرسول (صلى الله عليه والهـ وسلم) للامـام علي (عليه.

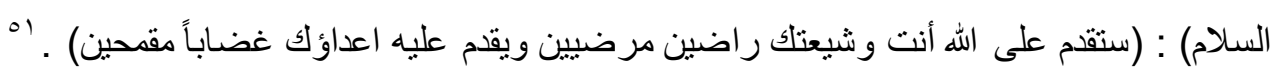

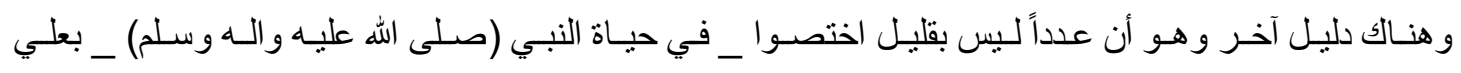

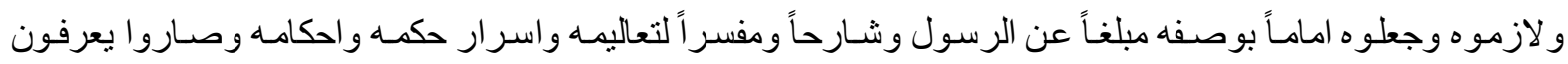

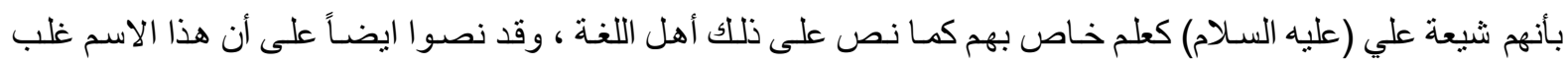

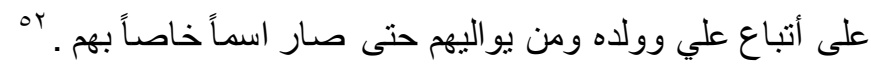

وان أهل البيت (عليهم السـلام) لا يعدون الرجل تابعاً وشيعة لهم الا اذا كـان مطبعاً لأمر الله مجانباً لهو اه آخذا

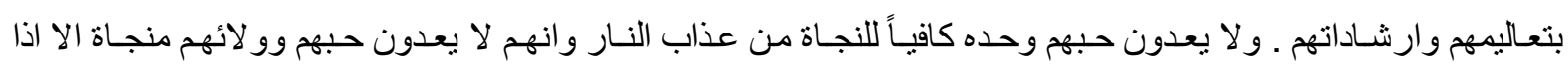

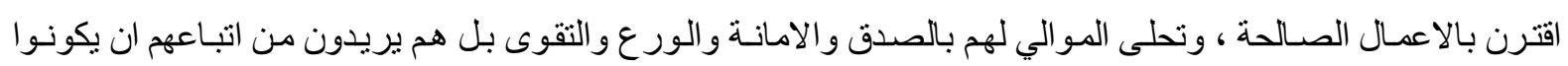

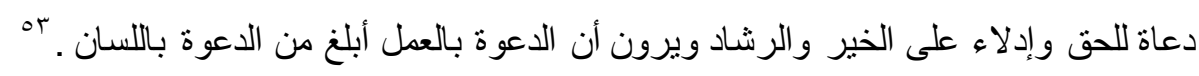

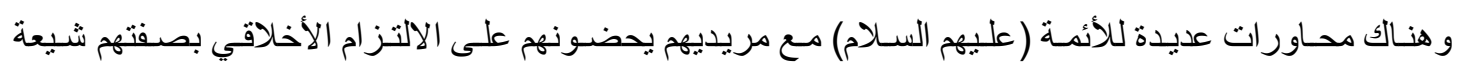

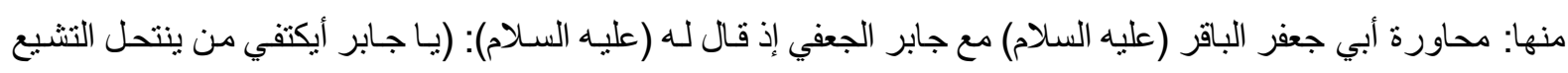

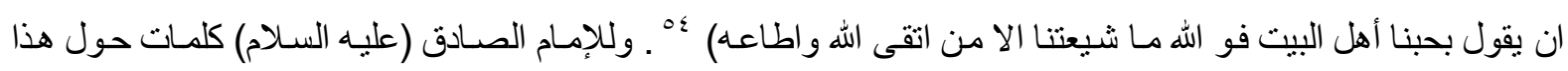

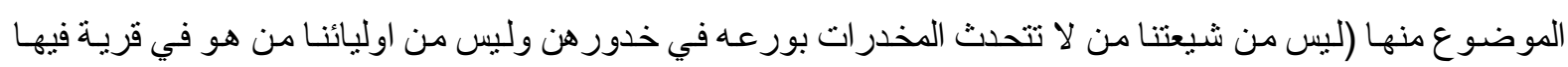

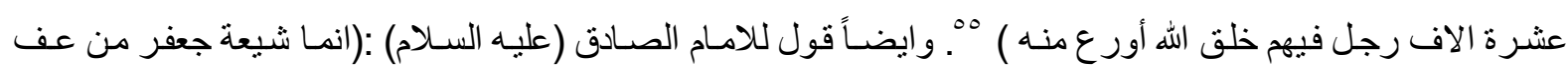

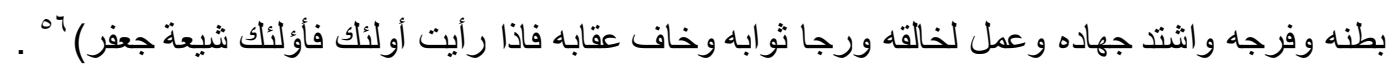


و هناك من الباحثين من يقول ان الثيعة لم تتكون الا في زمن الامسام الصـادق (عليه السـلام) ومنهم الدكتور علي

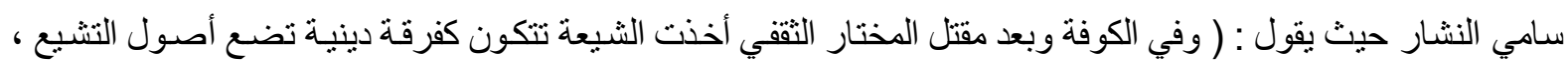

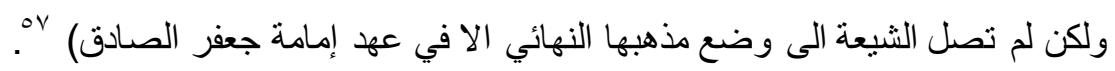

نقول إننا حتى لو سلمنا بهذا القول وقبلناه ، فإن بعض الباحثين من أهل السنة لم برتضوا ذلك إذ ردوا على هذا

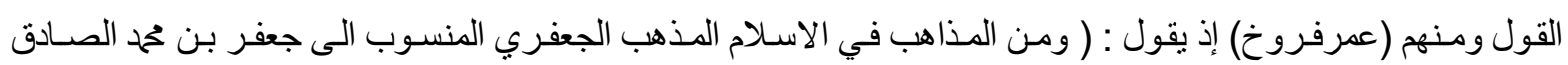

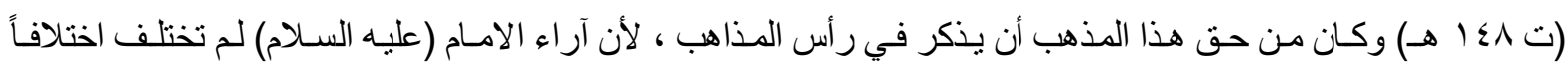

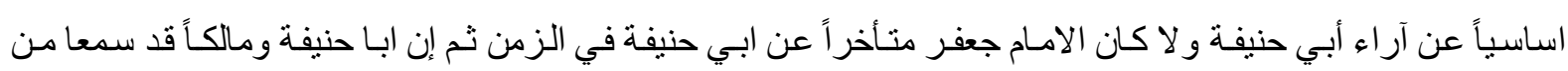

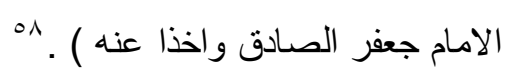

وان المذهب الثيعي كما قلنا سابقاً متأصل في التاريخ الاسلامي ومنتشر ايضاً لجملة اسباب منها: ما أورده صاحب كتاب أصل الشيعة هو : ((أن من أسباب انتشـار التشيع هو سبرة الامـام علي (عليه السـلام)

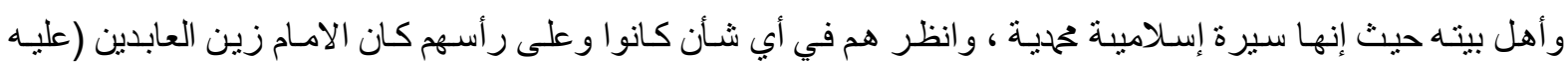

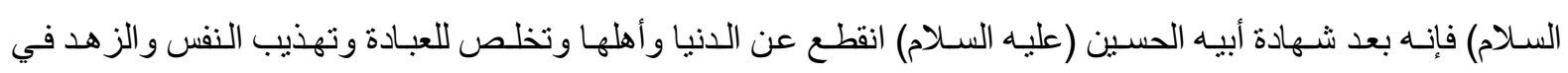

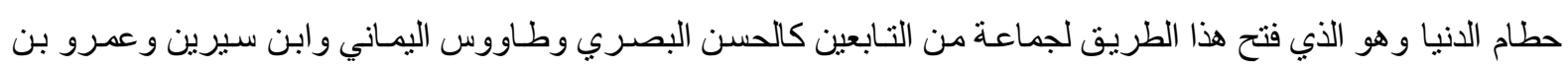

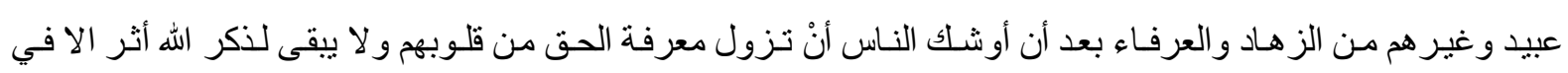

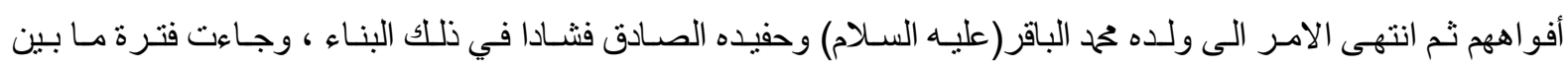

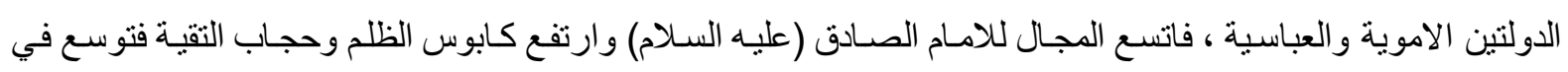

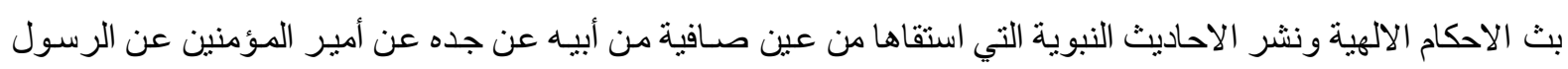
(صلى الله عليه واله وسلم).... ().

فالكلام يدل على ان أصل الشبعة يرجع الى زمن الرسـول (صلى الله عليه والهـ وسلم) وليس الى زمن الإمسام

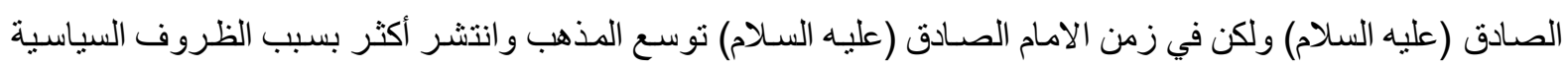
المختلفة التي كانت انذاك أو بسبب تخلخل الظروف السياسية ممـا ادى الى انتشـار اراء الامسام الصـادق (عليه السـلام) ، ولعل هذا هو السبب الذي دعـا بعضهم للقول بـان الشيعة ظهرت بوصفها فرقة اسـلامية في العهد الإمـام الصـادق (عليه. (السلام) (

وأيضـاً فـإنَّ من يكتم صـوت الحق ويحساول ان يهدم الحق فالنساس تخالفهه ، وقد نقل الثـيخ كاثـف الغطساء هذا المعنى عن الشعبي في قوله لولده :( بـأن من يكتم صوت الحق ويحـاول أنْ يهدم الحق فلالناس تخافهـ وتخالفه ....... يـا بنـي

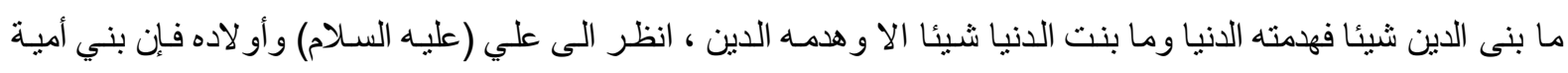

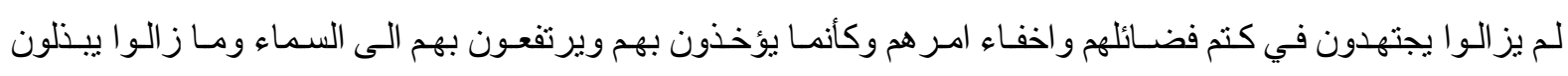

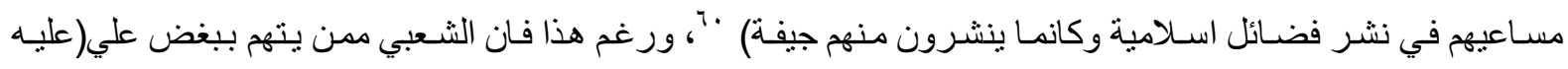

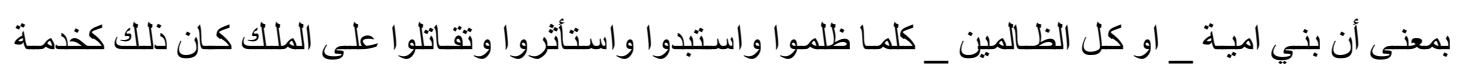

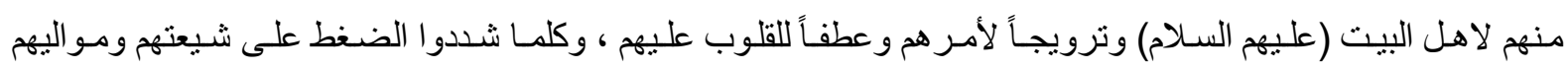

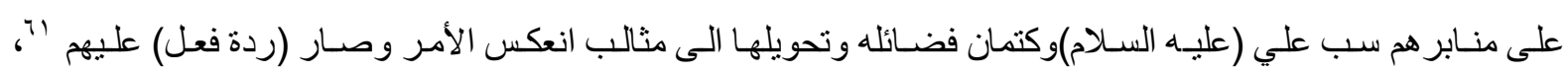

\section{- YVO}




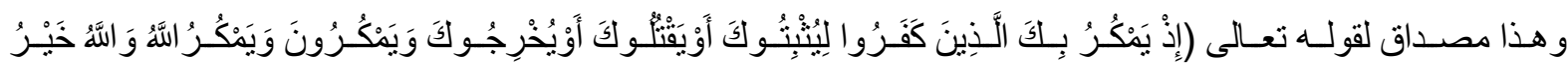

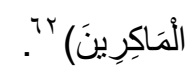

أقول إنَّ من اقبل على الدنباومباهجها والترف الذي فيها فـإنَّ الخيريبتعد عنه ويجانبه الذكر الحسن ويصبح من

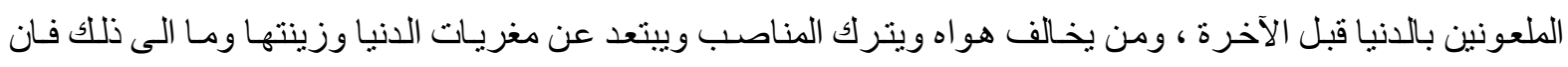
الدنيا تقبل عليه بالذكر الجميل والثناء الجليل والسمعة الطيبة وهذا ما حدث لجميع أئمة أهل البيت (عليهم السلام) قاطبة . و وليه يتضـح بـان الثيعة من أقدم الفرق الاسلامية ؛لانها نشـأة في عهد الرسول (صلى الله عليه والهـ وسلم )

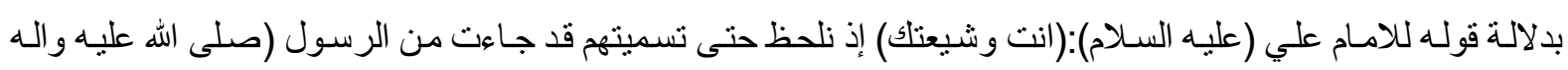
وسلم ) و عليه فهم أقدم فرقة اسلامية تأريخاً ووجوداً.

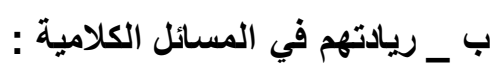

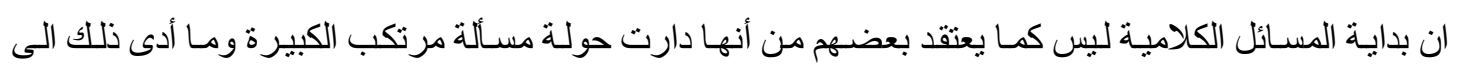

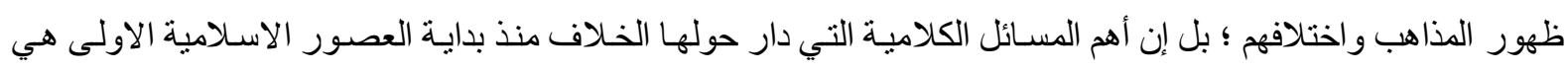

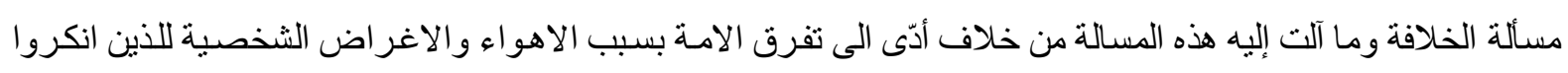
الحق وتمسكو البالباطل .

أمسا نظرة الثيعة الامامية لهذه المسألة فيمكن توضيحها بالشكل الآتي: إنَّ الامامية كلهم متفقون على أن النبي

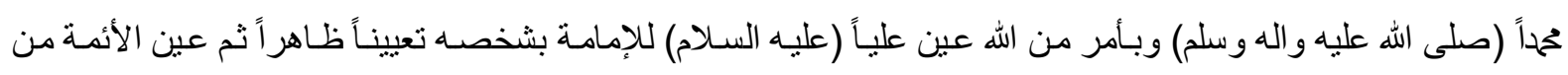

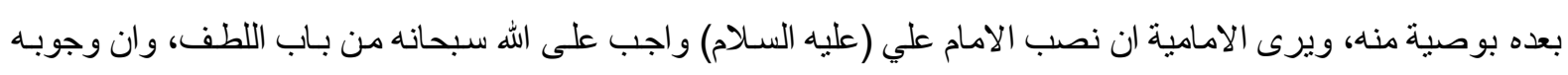

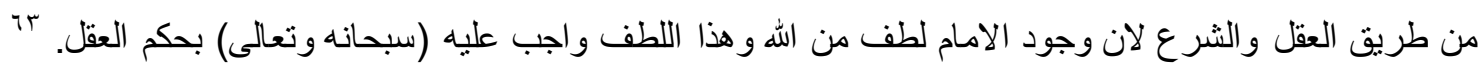
وهناك من كتـاب أهل السنة مـن يعترف للإمـام (عليه السلام) بالريادة في العلم سواء كانت علومـاً شـرعية أم

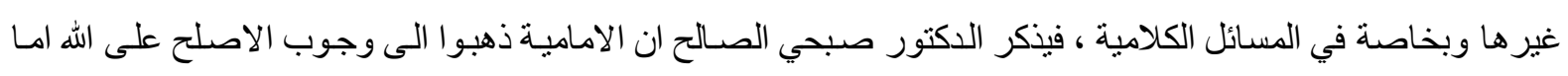

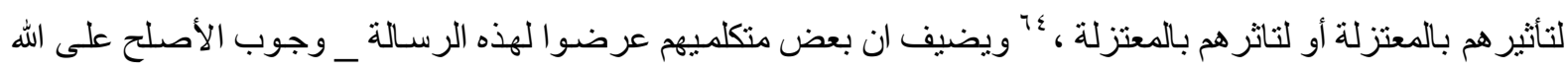
_ قبل شيوخ المعتزلة .

أمسا مسألة الجبر و التفويض فنجد الامـام علي (عليه السـلام) أول من قـال رأيـاً فيهـا قبل التـابعين ، وقبل شيوخ المعتزلة ونورد نصاً لهذا الموضوع ورد في كتاب (المنية والامل) لابن المرتضى وهو ( جاء رجل للامـام حين منصرفه

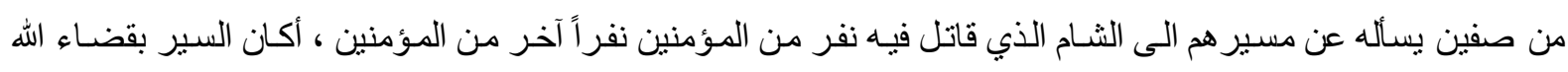

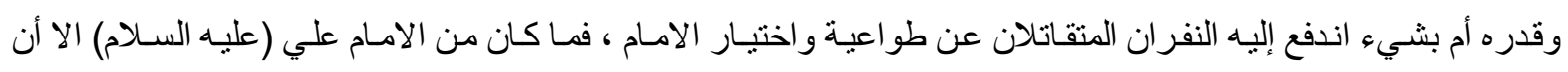

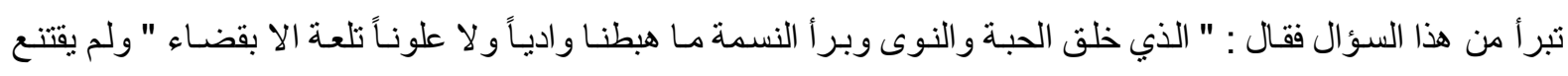

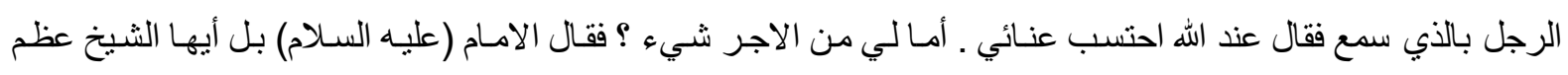

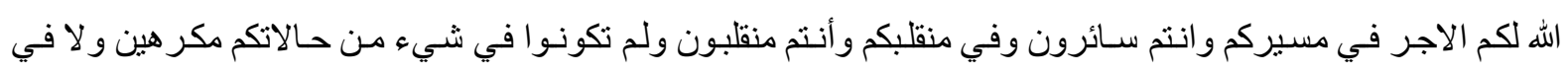

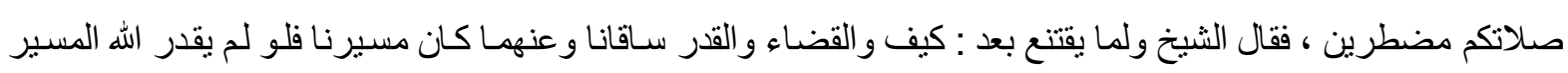

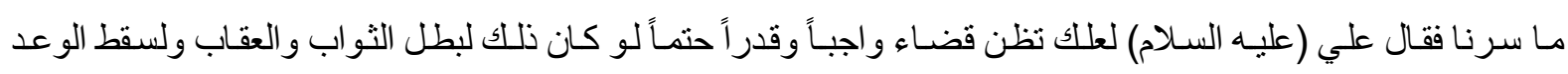

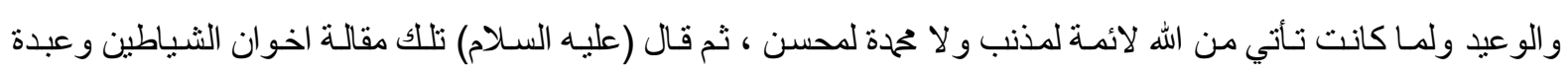

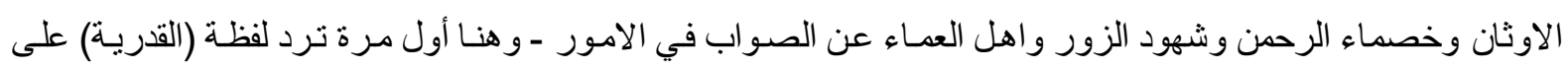


لسان الامام (عليه السلام) تصف قوماً يتكلمون في شؤون الغيب والقضـاء والقدر فـاذا هو يسمي اخوان الشياطين بالقدريـة

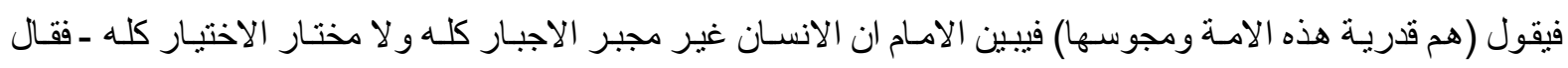

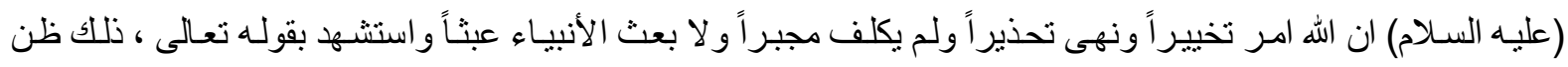

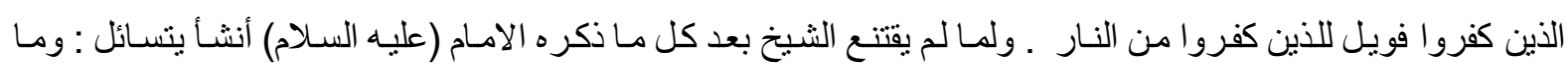

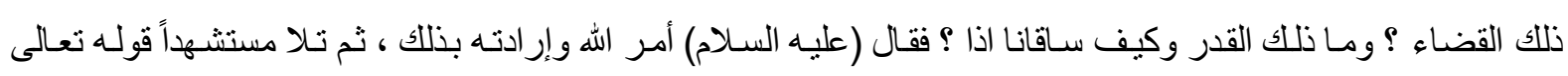

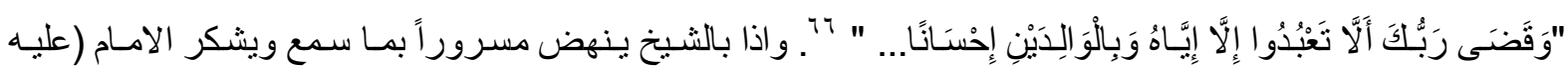

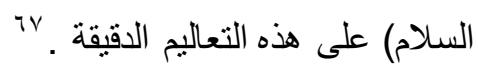

أمسا مـا أورده الكتاب المحدثون عن ريادة الشيعة للمسـائل الكلامية فمنها نص للدكتور صبحي الصـالح إذ يقول :(ولئن خالفنـا الاماميـة في عقيدة الامامـة والوصـاية والرجعة فنحن لا ننكر انـه قد كان لهم الفضل الاكبر في انشـاء هذا

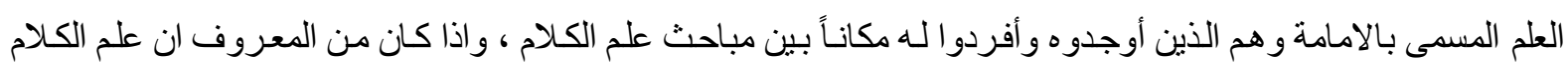

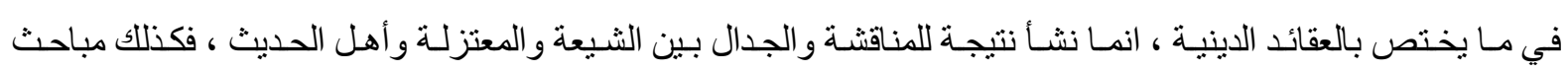

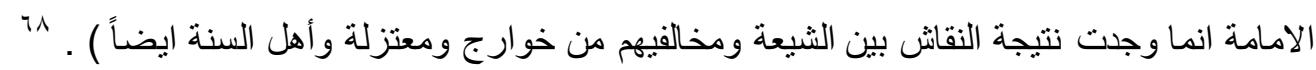
فهناك من علمـاء الشيعة البارزين من ألف في الرد على المخالفين وخاضوا في مبحث الامامـة بشكل خاص ،

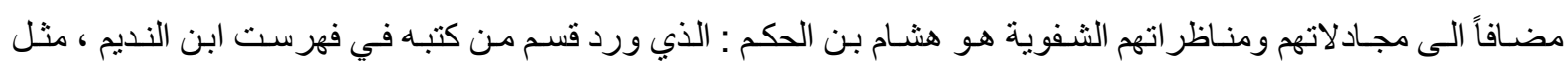

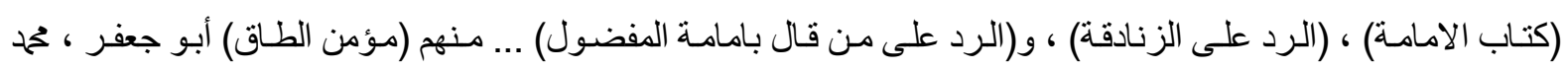

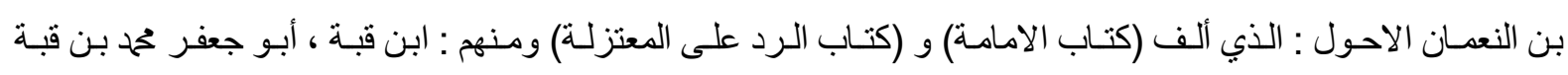

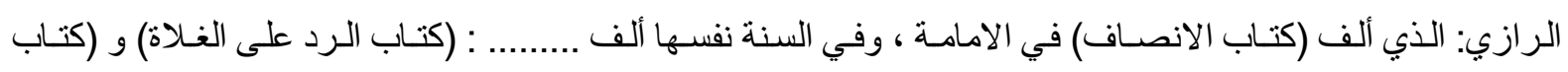

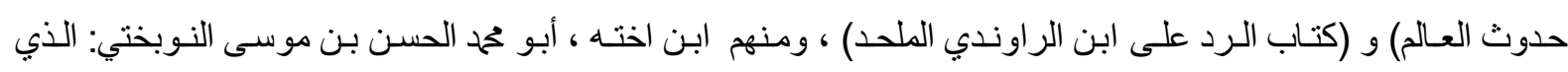

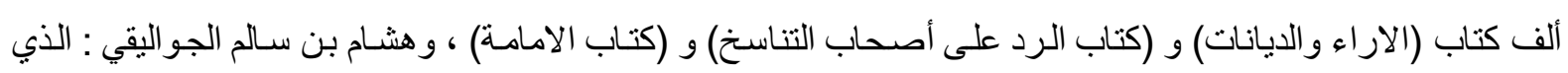

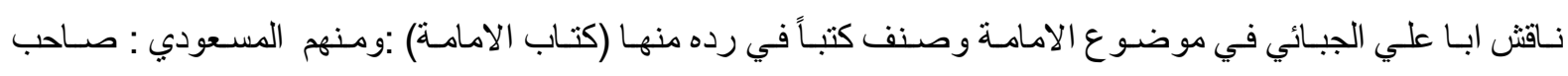

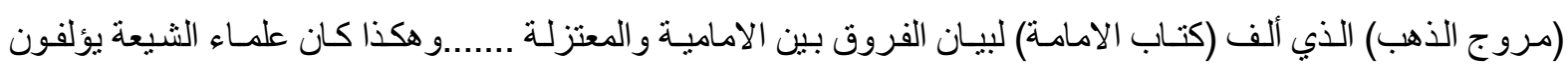

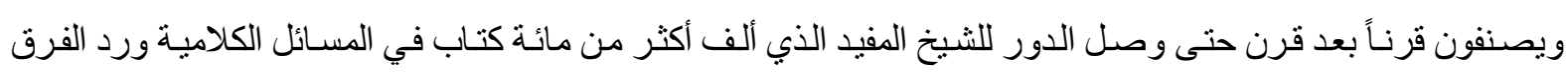

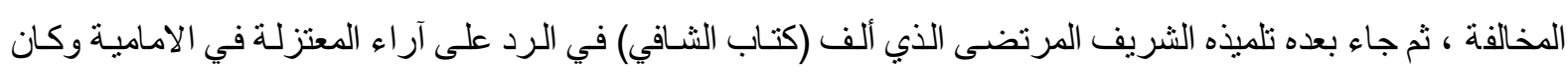

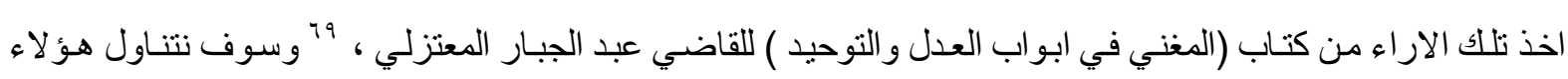

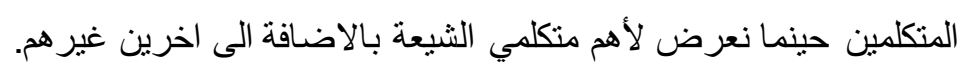

بهذا يتضح ان الامامية هم أول من اسس لعلم الامامـة ، وبذللك يكونون هم أول من اسس علم الكلام على وجـه

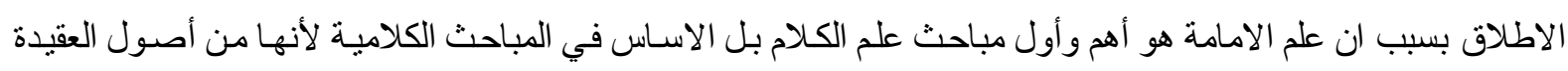

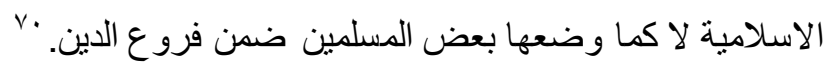
ومن الأدلة على ريادتهم في علم الكلام هو نبوغ الشيعة في هذا المجال منذ بدايـة الاسـلام حتى عصرنا الحسالي

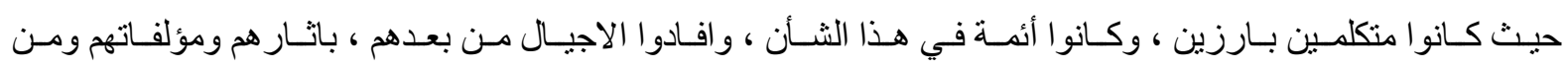
مشاهير هم: 


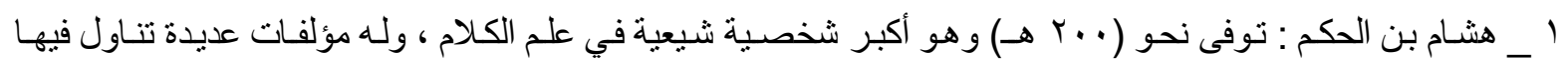

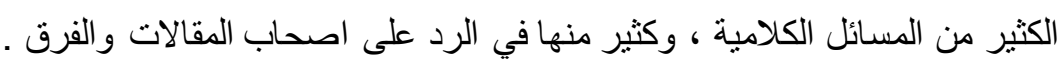

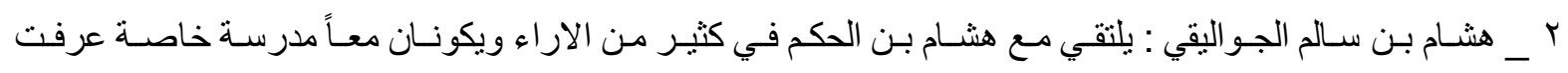
بالهشامية.

ץ _ أبو جعفر الاحول محمد بن النعمان : المعروف عند الثيعة باسم (مؤمن الطاق) وعند غير هم بـ (شيطان الطاق) .

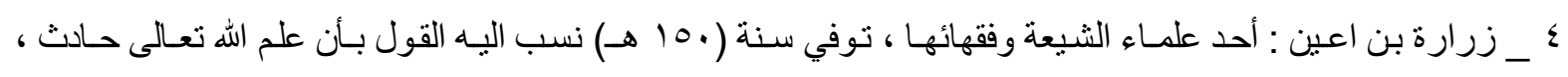

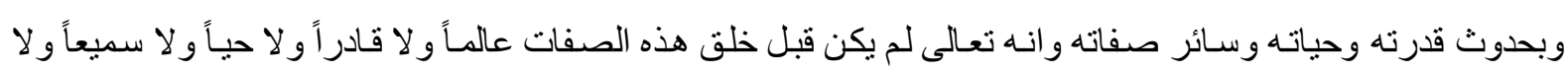

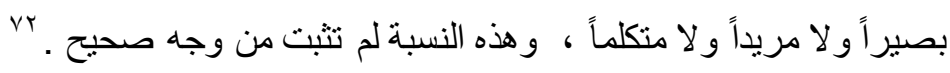

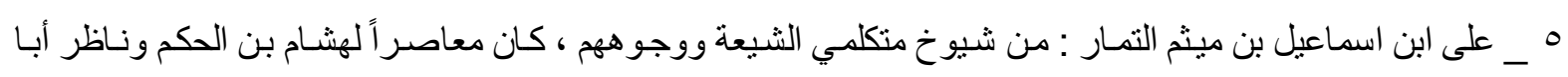
الهذيل العلاف وضـرار بن عمرو الغبي وابـا اسحاق النظـام ولـه مؤلفات في الامامـة وغير هم ، وقد أورد (الثيخ المفيد)

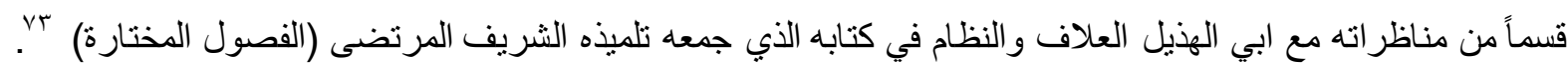

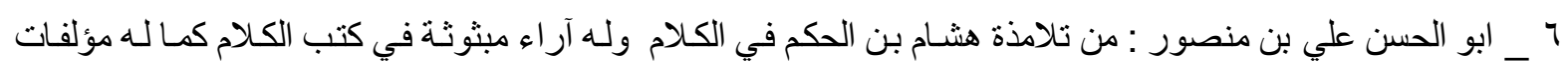

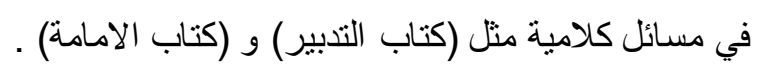

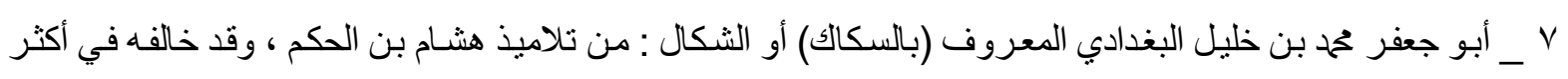

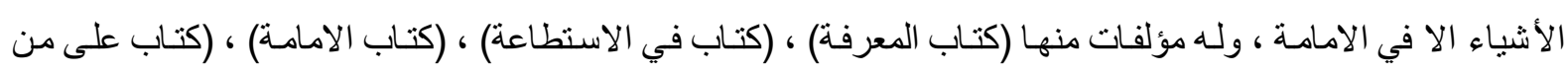

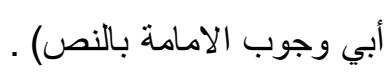

^ ـ أبو عبد الله بن مملك الاصفهاني : مـن متكلمي الثبعة ، ولـه مـع أبي علي الجبائي مجلس في الامامـة ، وتثبيتها

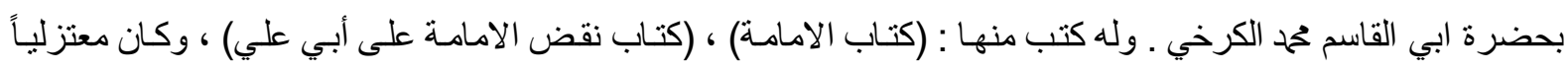

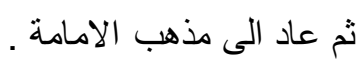

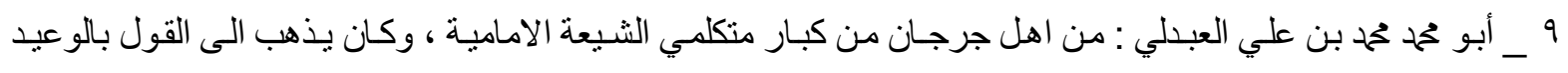

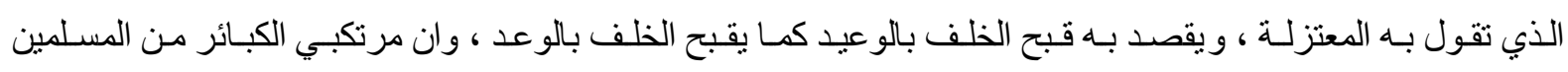

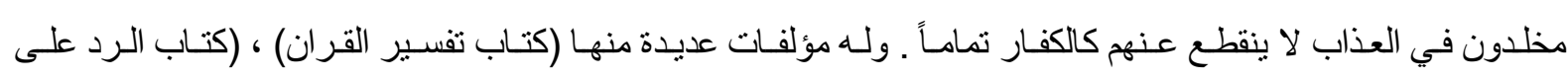

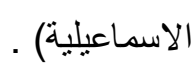
• ـ ـ أبو منصور الصرام : من أهل نيسابور ، ومن أجلة المتكلمين ، وكـان يذهب الى القول بالوعيد ، لـه كتب كثيرة

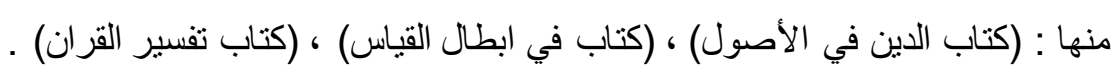

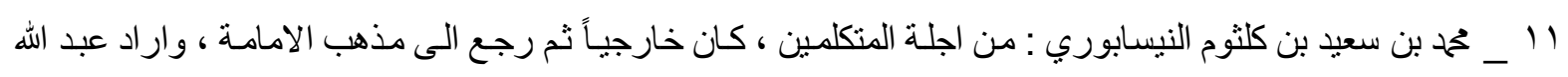
بن طاهز اعتقاله ، فحاجه محمد بن سعيد فخلى سبيله .

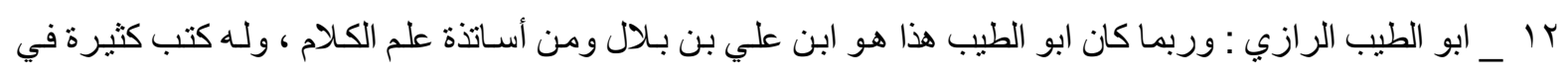

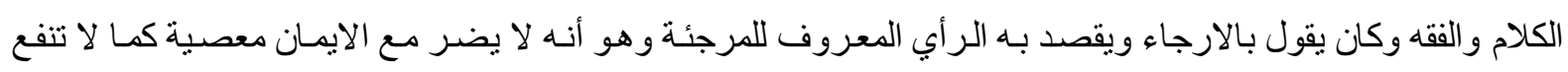

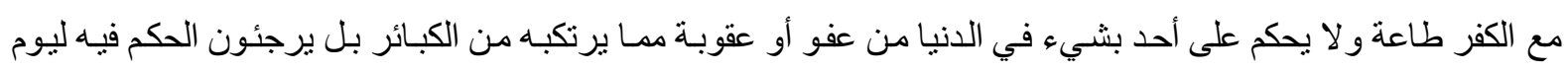

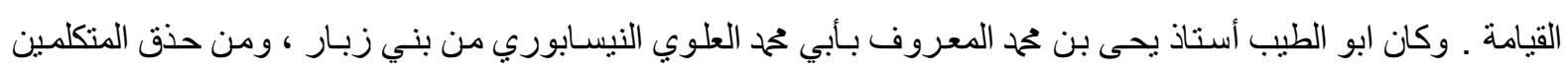
و المؤلفين في علم الكلام . المان.

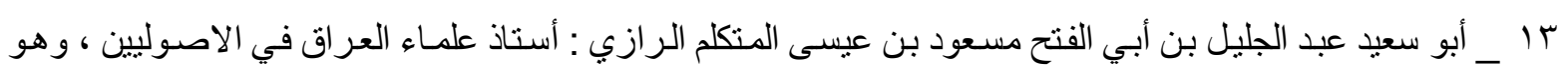
مناظر حاذق ، له : (نقض كتاب التصفح لأبي الحسن البصري) ، (الفصول في مذهب ال الرسول) ، (جوابات علي بن 
أبـي القاسـ الاسـتربادي) ، (جوابـات مسـعود الصـوائي) ، (مسـألة فـي المعجزز) ، ( مسـألة في المعـدوم) ، (مســألة في

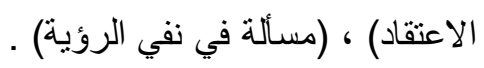

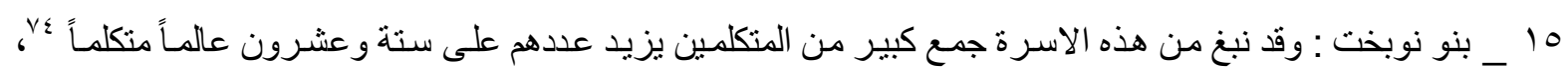

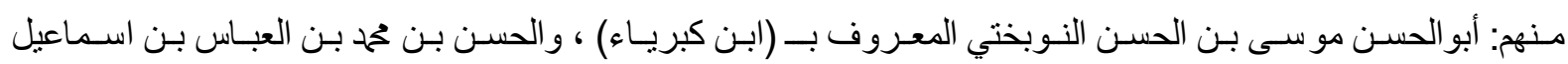

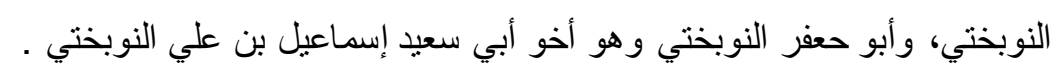

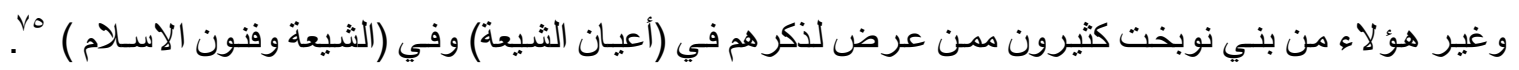
ومن منكلمي الشيعة أيضاً:

أبو سهل البغدادي ، داود بن أسد بن أعفر الاحوص البصري ، خليل بن الغـازي ، عبد الله بن الحسين اليزدي ،

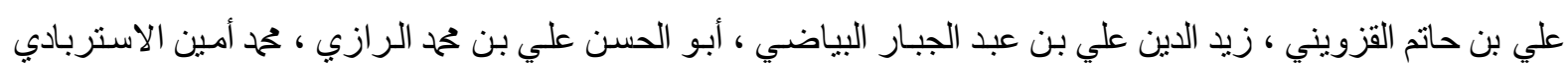

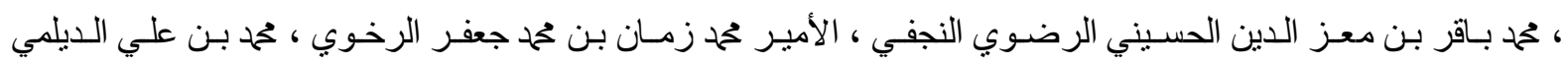

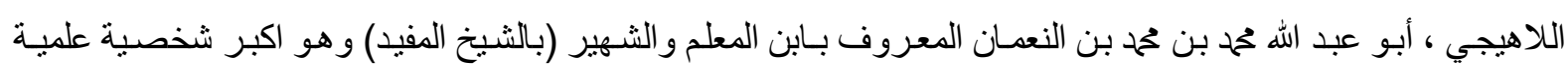
في الفقه والاثار والكلام وغير ها في القرن الرابع الهجري ، وقد ذكره ابن النديم فوصفه بقوله : " ابن المعلم أبو عبد الله

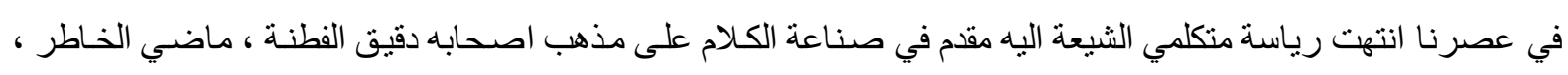

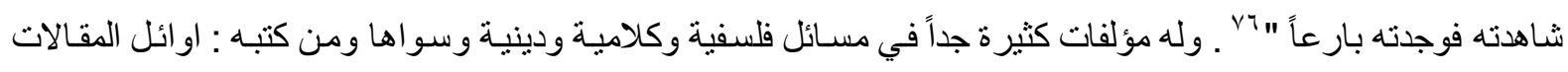

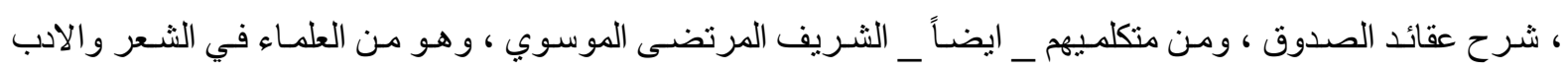

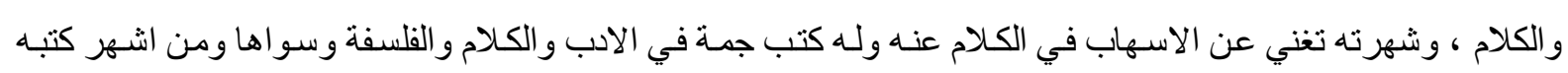

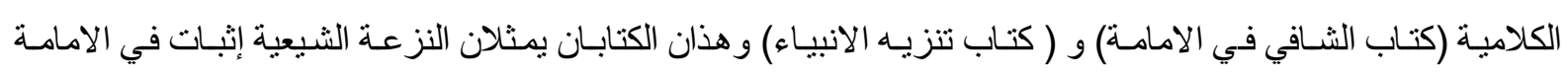

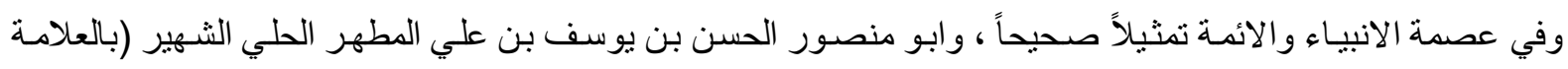

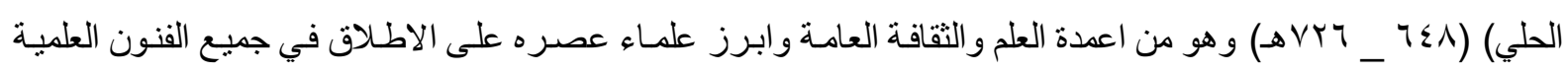

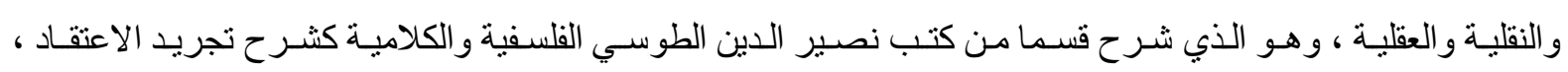

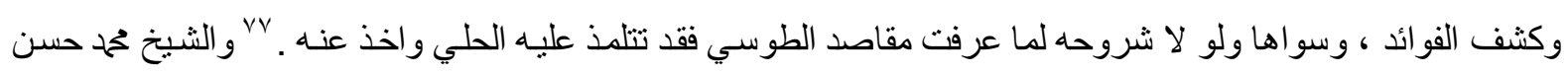

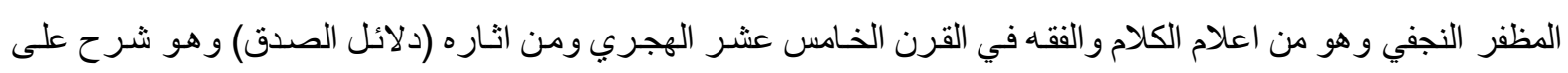

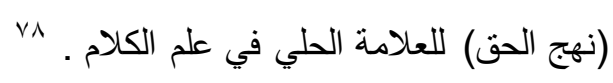

وبهؤ لاء العلماء نكتفي لان متكلمي الثيعة لو أردنا احصاءهم لكان شيئاً مما يتعذر علينا لذا كتفينا بهؤلاء "va اما آراء الثيعة فمنها ما امتازوا بها من حيث الفكرة أو من حيث الاسلوب ، من ذلك : قولهم في افعال الانسـان

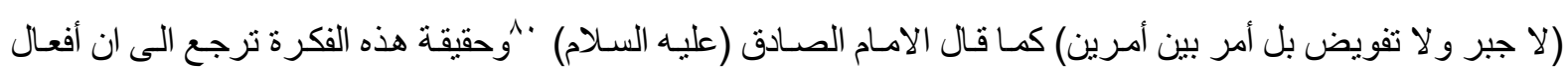

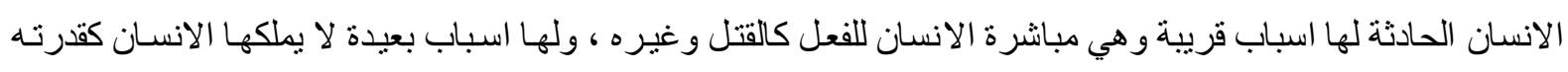

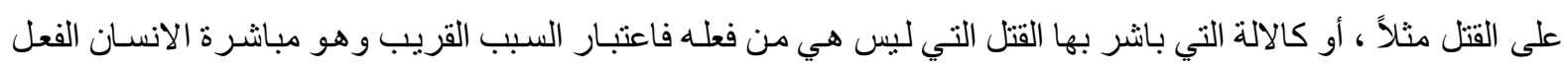

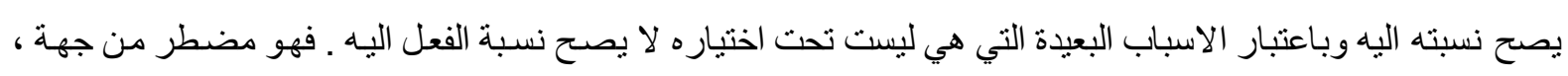

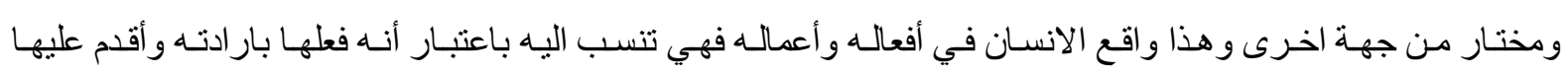

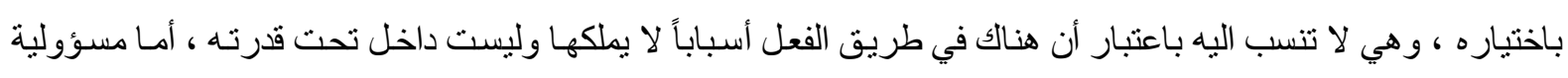

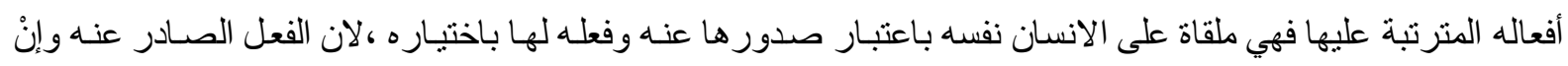


كان بعض اسبابه التي تقع في طريق انجازه لا يملكها الانسـان ، الا ان تلك الوسـال التي و هبها الله اياهـا و اقدره بهـا على

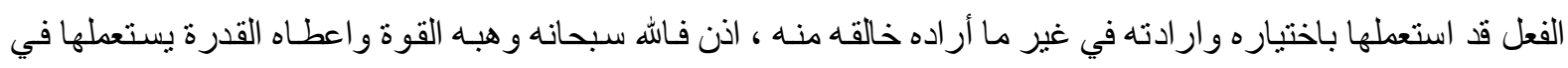

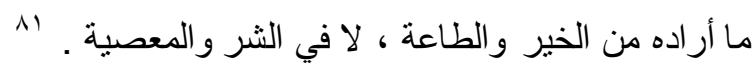
وقد احتلت مسألة الجبر والاختبار المكان البارز بين المسـائل الدينية وكانت محل تسـاءل حتى لدى كبار الفقهاء

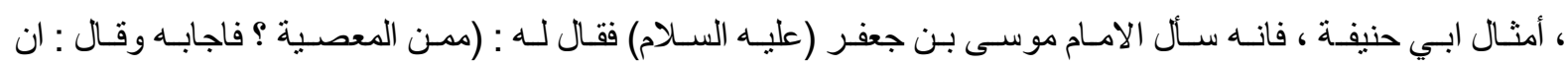

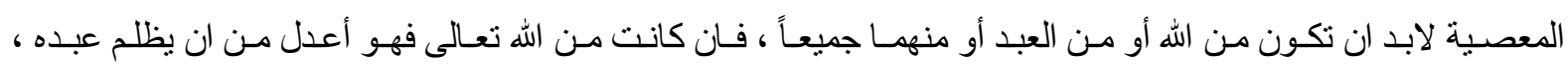

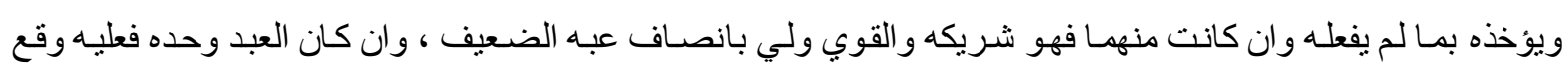

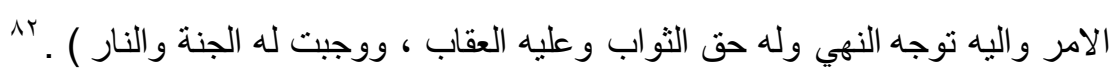
و الثيعة هم أول من استدل على اثبـات الصـانع بدليل عقلي من دون الحاجة الى مـا هو معروف عند المتكلمين

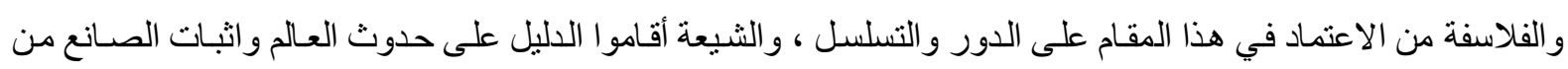

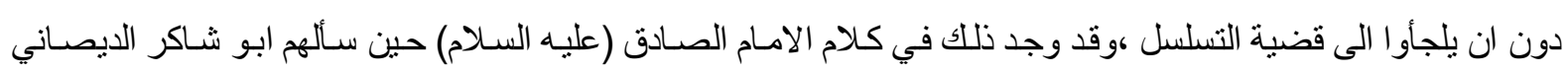

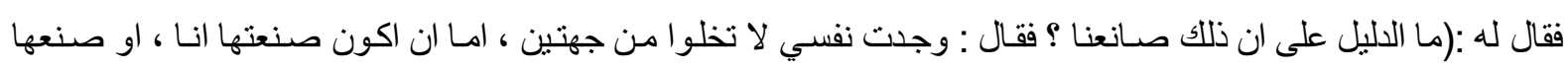

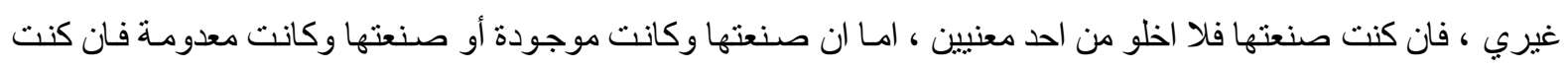

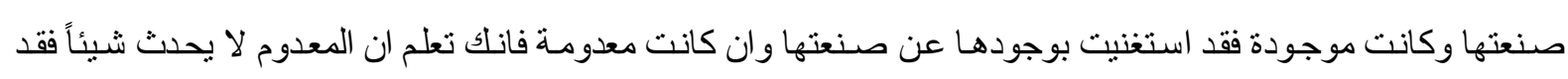

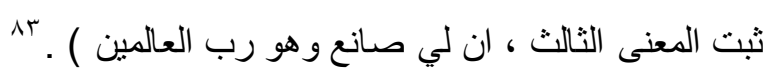
وقد ترك متكلموا الثـيعة اثـار غنيـة بـالفكر و المعرفـة في جميع المسـائل الكلاميـة التي عالجوهـا ، وكمـا عنوا

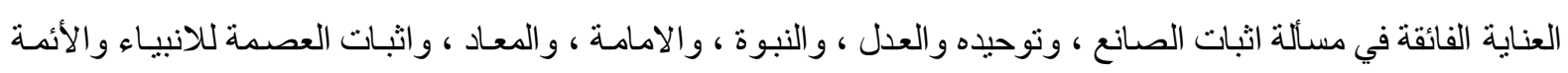

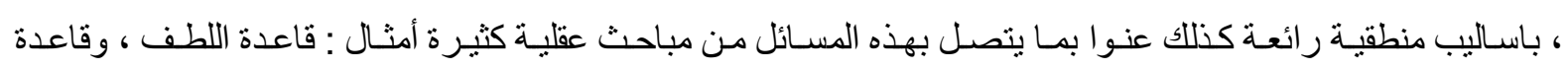

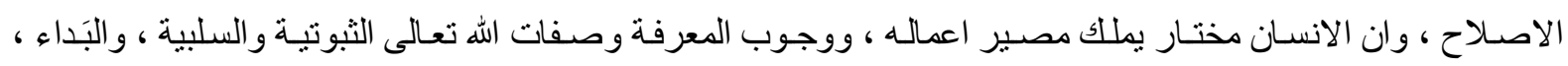

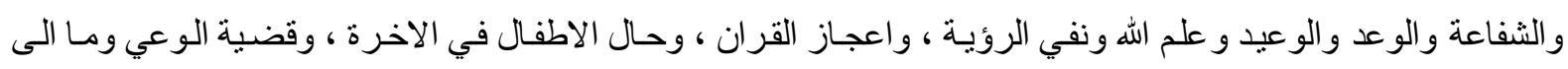

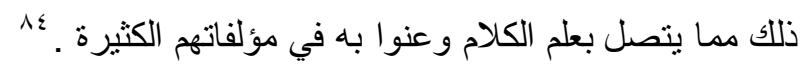
وقد وضعو ا في التوحيد مؤلفات كثيرة جداً تتجاوز المئات ، وقد عرض الطهر اني في كتابـه (الذريعة) في مـادة

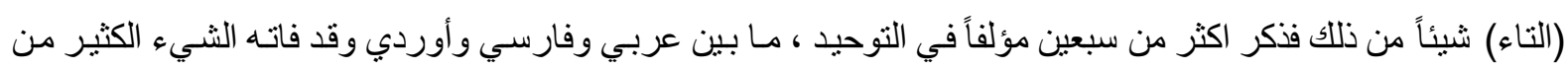

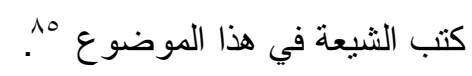
ومن آثار الثيعة القيمة في التوحيد كتاب (الاهليلجة) المعروف (بتوحيد المفضل) الذي رواه المفضل بن عمرو

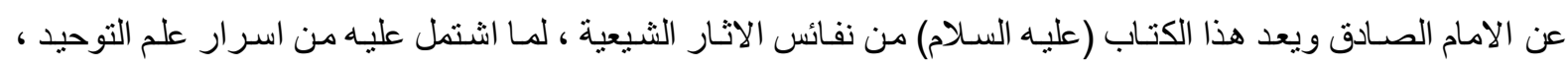

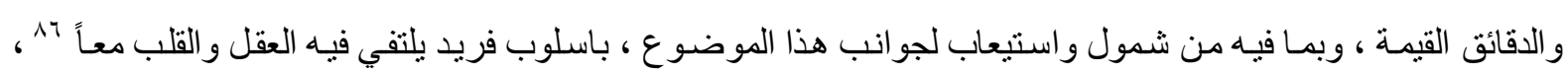

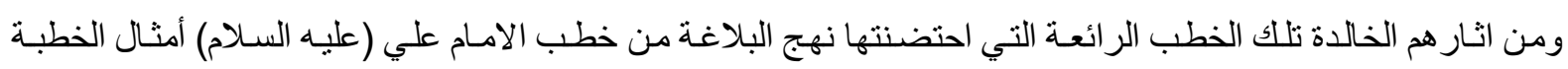

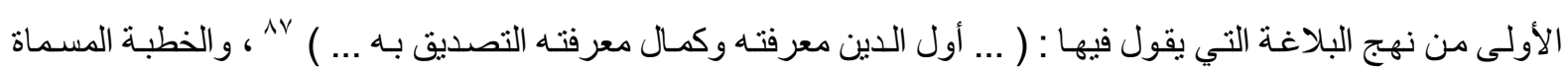

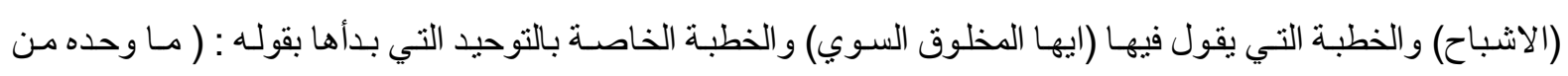

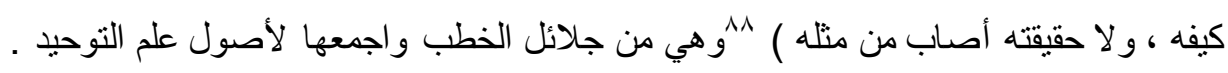


اما موضوع الامامة فقد كثرت فيه مؤلفات الثيعة كثرة هائلة منذ عصور الاسـام الاولى حتى عصرنا الحاضر

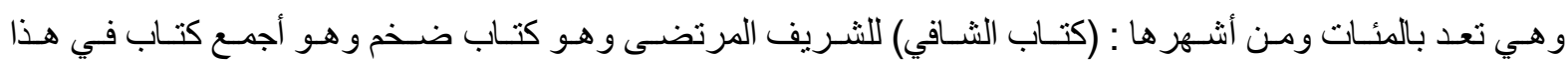

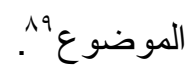

و أيضـا كتـاب نهج الحق للعلامـة الحلي الذي شـرحه و علق عليه ، ودافع عنـه العلامـة الشيخخ محمد حسن المظفر

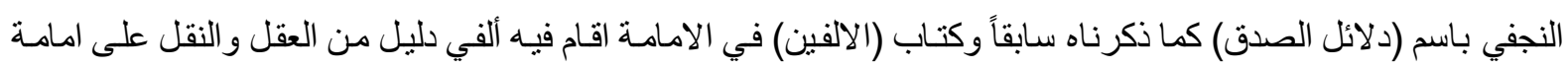

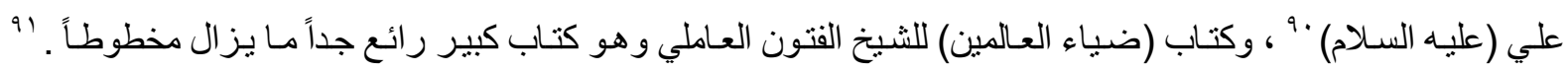

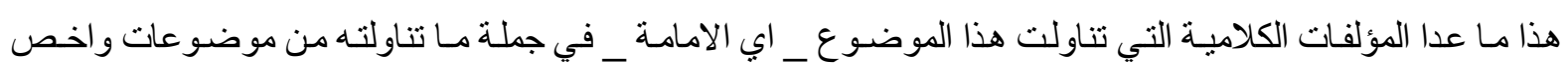

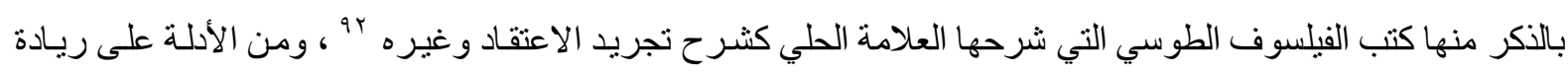

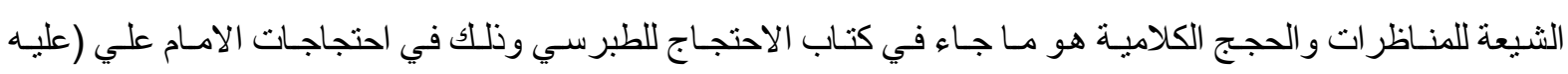
السلام) ضد معاوية والخوارج حيث إن أول الاحتجاجات كان في النصف الأول من القرن الأول الهجري وكان باحتجـاج

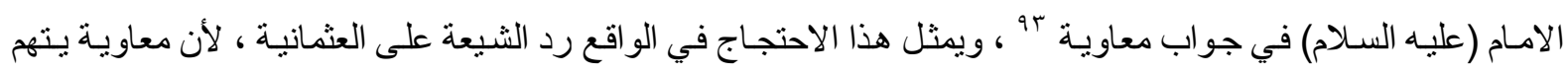

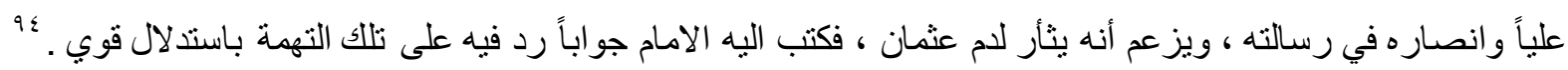
ومنها احتجاج الامام (عليه السـلام) ضد الخوارج الذين انشقوا بعد التحكيم حيث عدوا هذا العمل غير مشروع

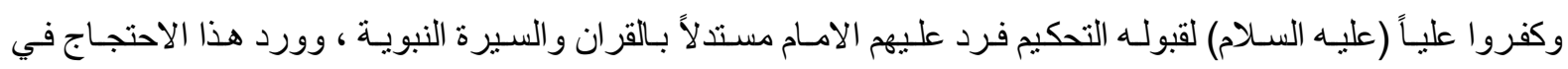

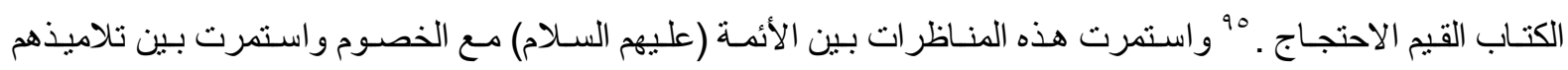

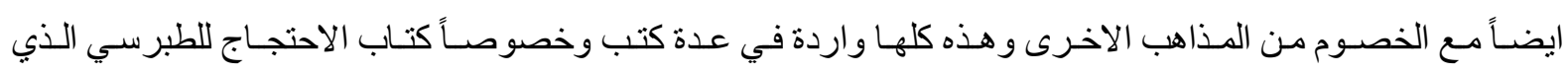
ذكرناه. واستمرت منل هذه المناظر ات في المر احل المتأخرة بين أنباع المذهب الاسـلامية ، وكـان عصر الامـام الصـادق

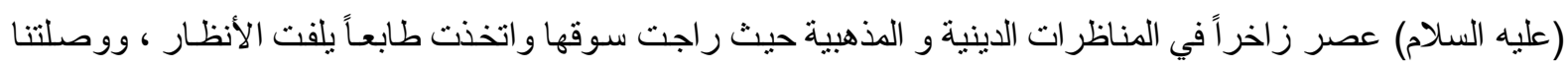

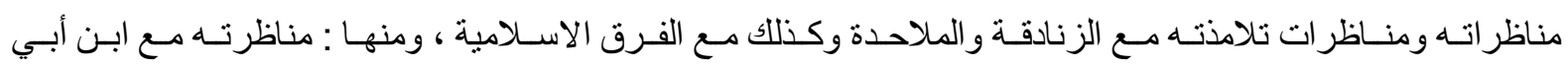

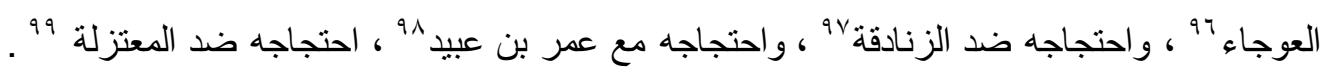
ج : المسائل الكلامية في نهج البلاغة : هناك مسائل عديدة ورنت في نهج البلاغة سوف نشير اليها ، ولكن من أهم المسائل الكلامية التي وردت في

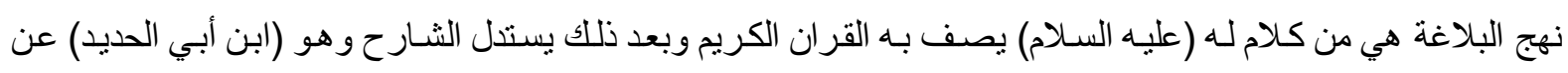

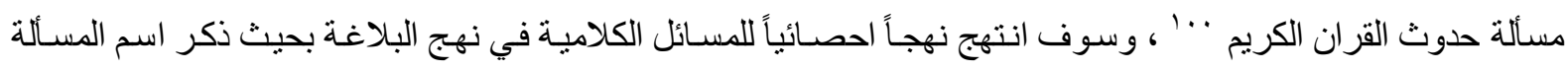

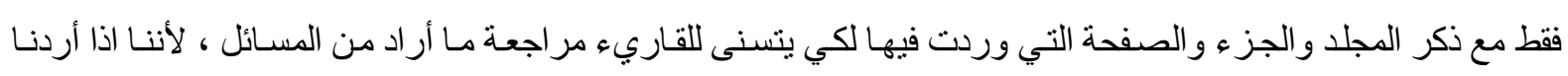
إيراد جميع المسائل بالتفصيل والتعليق عليها للزم لذلك عدة بحوث ومن هذه المسائل :

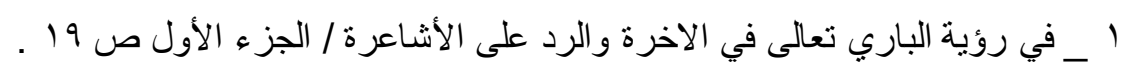

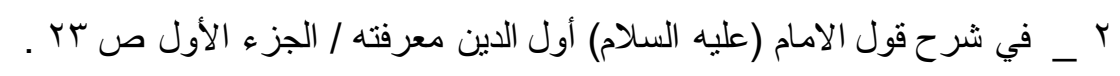

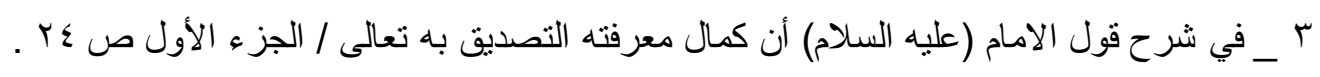

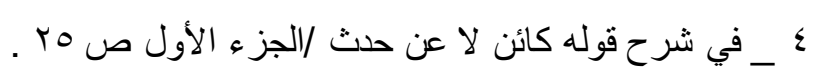

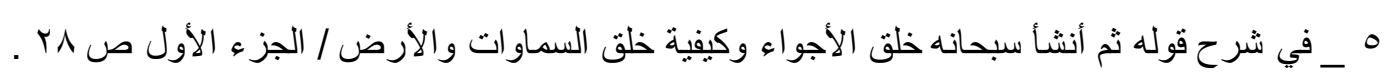




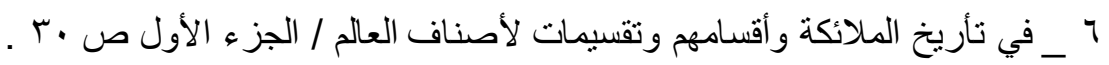

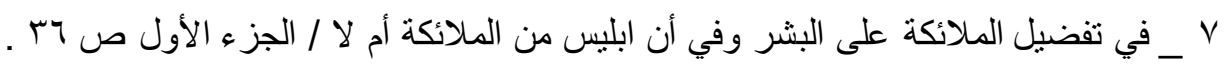

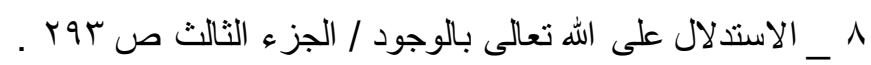

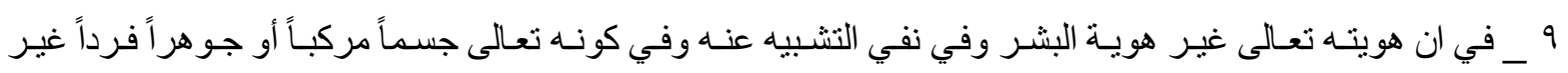

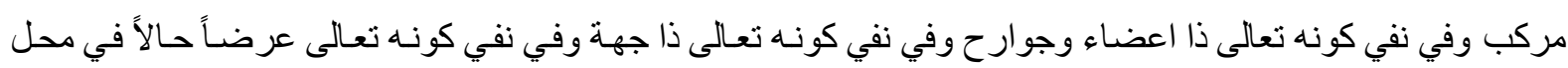

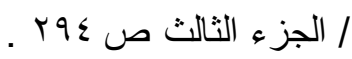

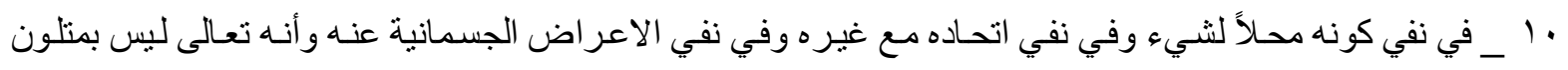

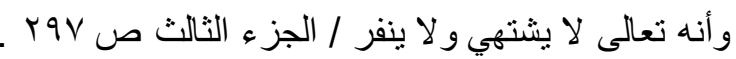

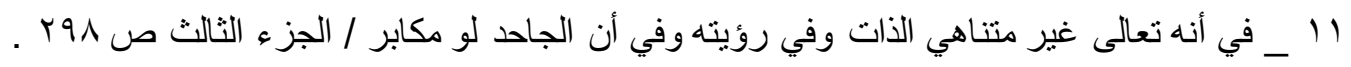

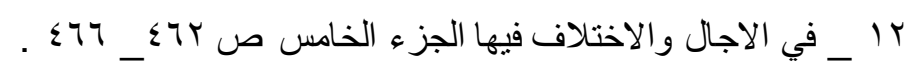

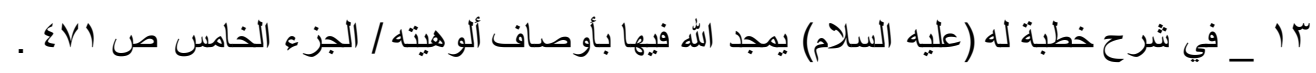

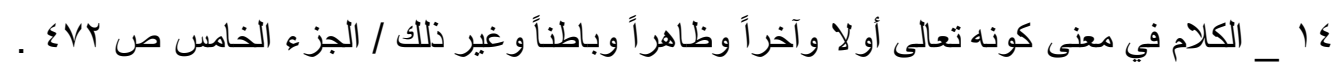

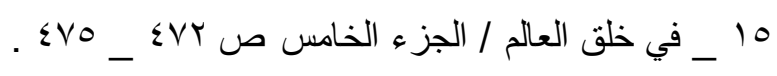

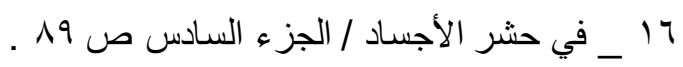

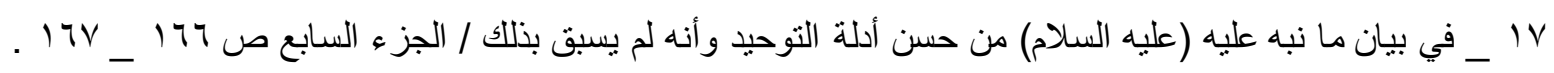

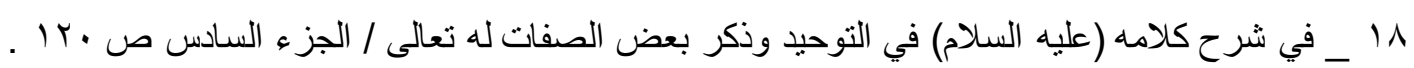

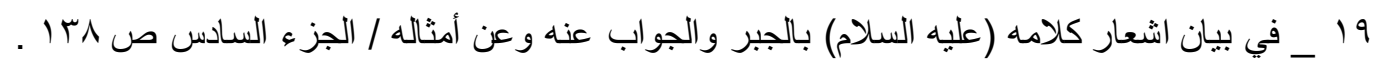

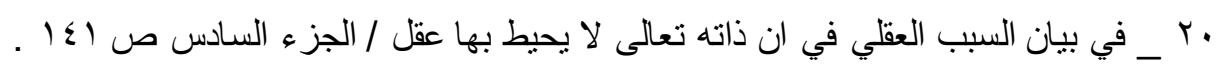

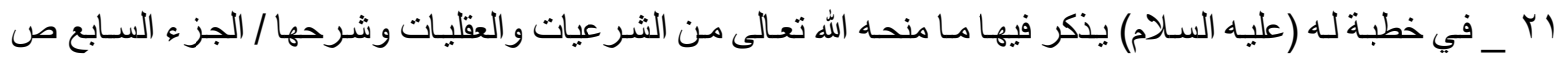

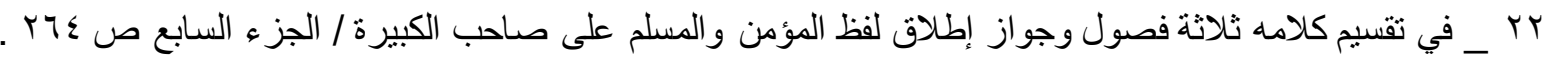

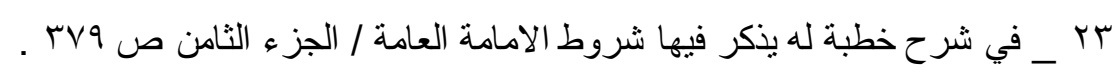

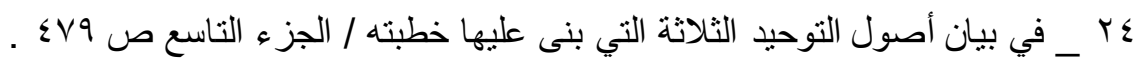

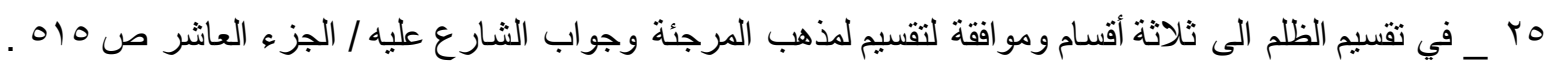

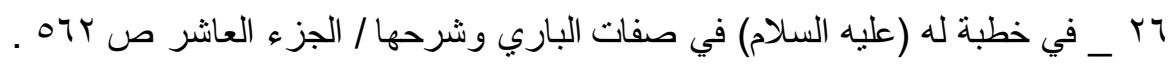

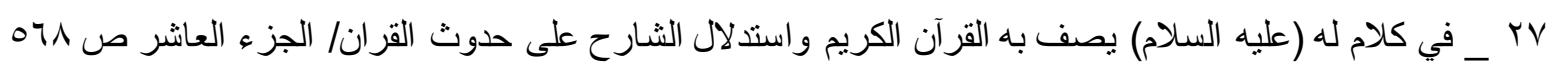

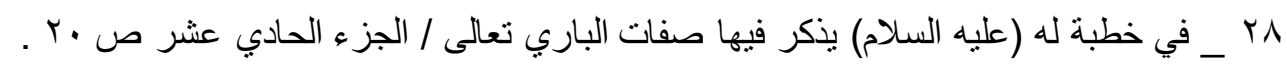

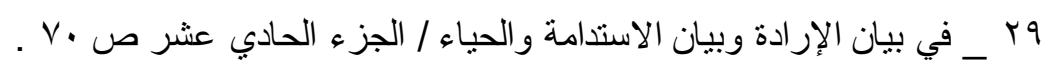

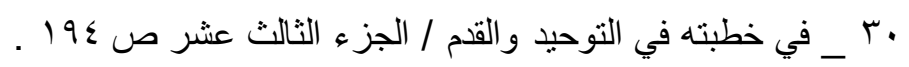

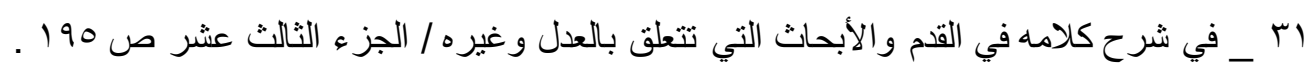

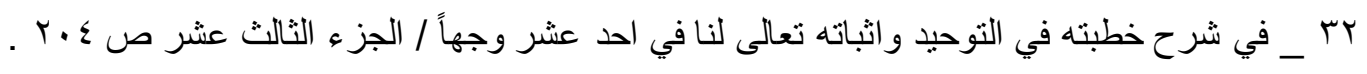

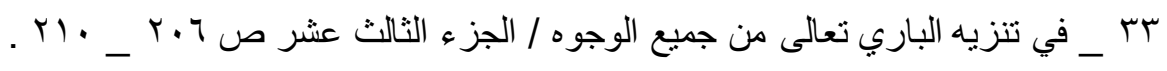

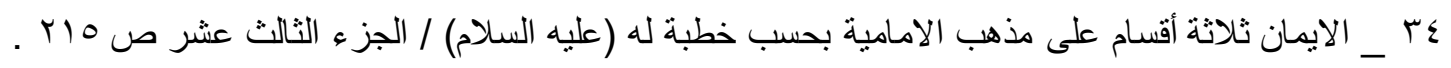


דr _ في كلام لله (عليه السلام) في القضاء و القدر قاله لسائل عند مسير هم الى الثشام / الجزء الثامن عشر ص rVV .

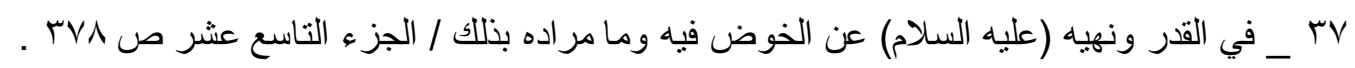

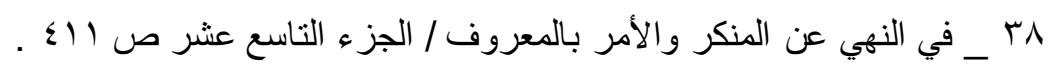

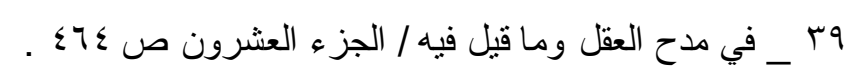

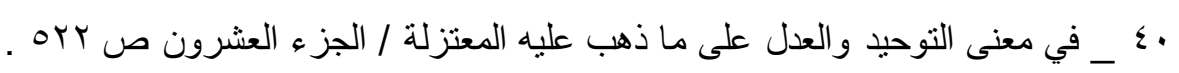

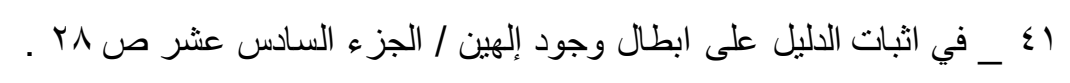

وفي النهاية هذا مجرد احصـاء قد يكون تامـاً أو قد يكون ناقصـاً ، وأنما أوردنـاه لكي نبين أن الامـام (عليه السـلام) قد تكلم بالعديد من المسائل الكلامية في العديد من خطبه ، وقد نطرق الى مسـائل لم يسبقه اليها أحد مثنل حسن أدلة توحيد الله

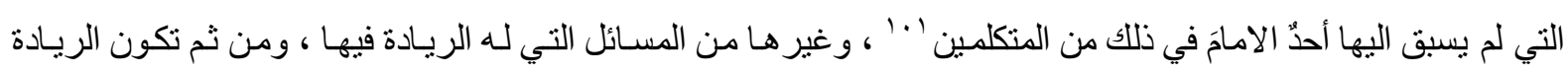
للشيعة بذلك محصلةً

خاتمة

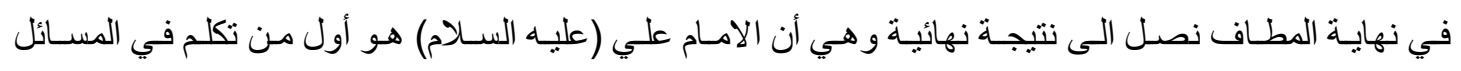

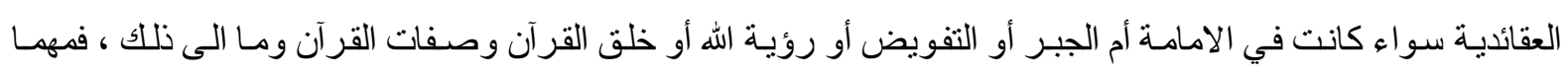
كان رأيه (عليه السلام) فإنّه له السبق في هذه المواضيع وإير اد الادلة عليها وإنْ كانت أدلة بعيدة عن الاستـلال المنطقي

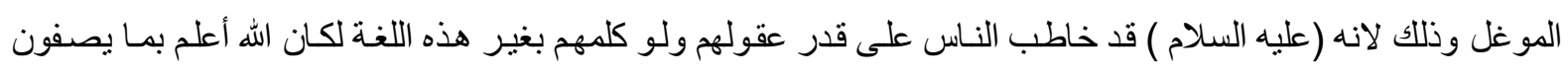

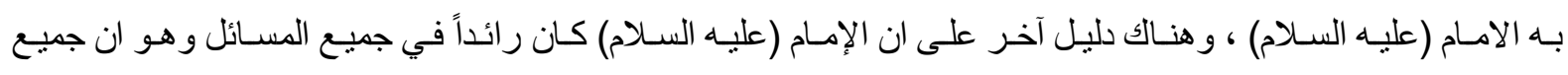

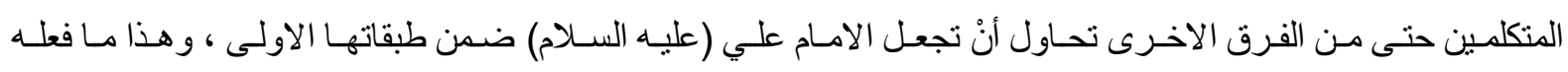

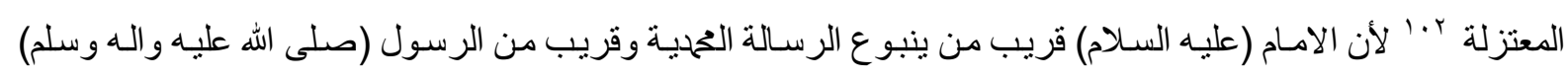
ومصاحب له طوال حياته ولذلك فهم يتقربون أو يجعلون الامام (عليه السلام) من طبقاتهم الأولى أو من أساتنتهم.

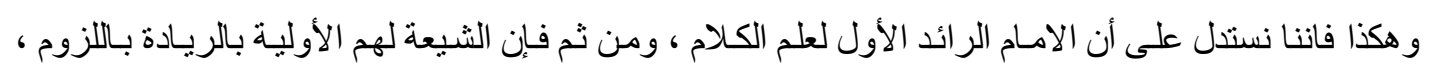

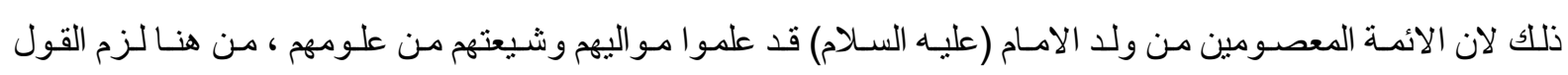

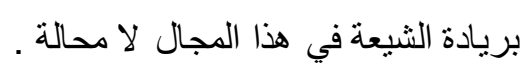

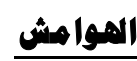

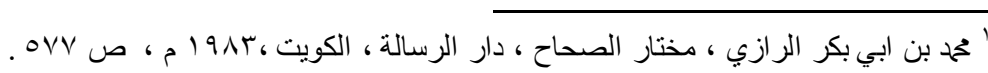

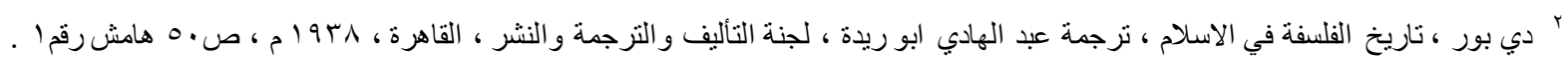

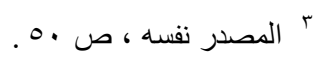

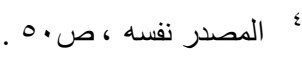

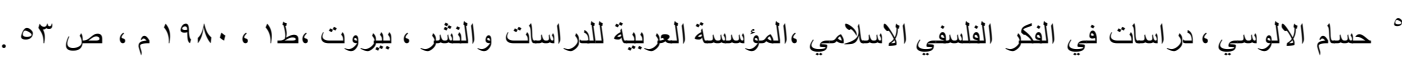

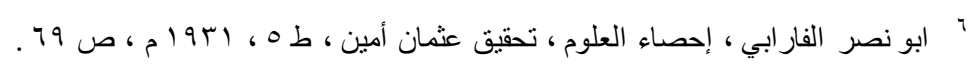

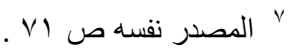

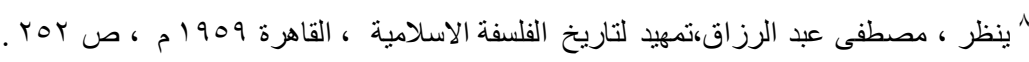

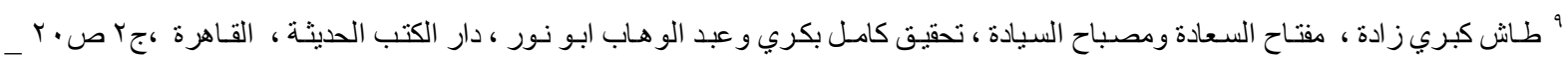

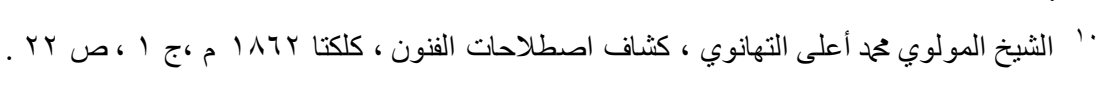




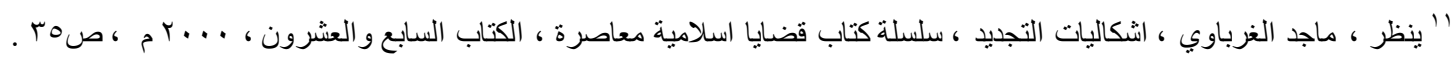

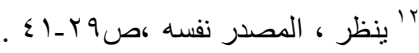

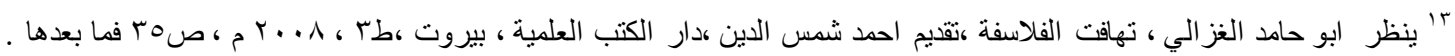

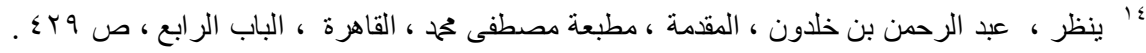

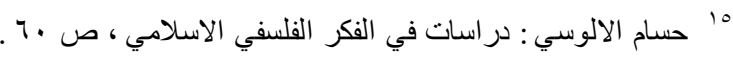

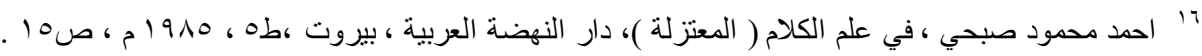

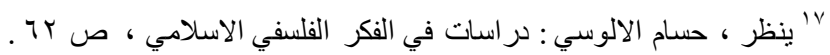

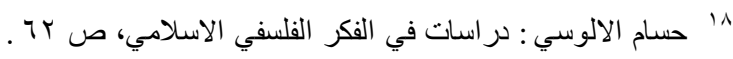
19 ينظر،عضد الدين عبد الرحمن الايجي ، المو اقف ،شرح الثريف علي بن محمد الجرجاني مـع حاثشيتين لعبد الحكيم السيالكوتي وحسن جابي شـاه

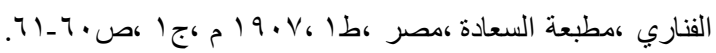

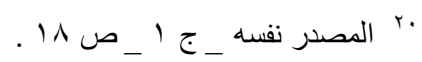

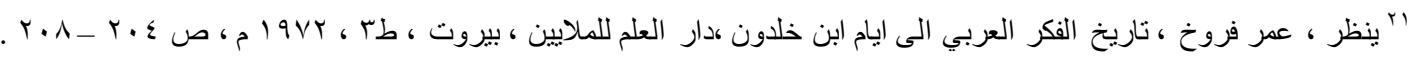

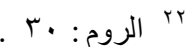

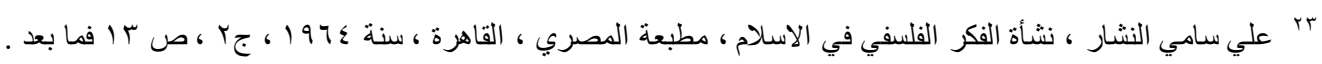

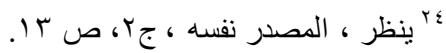

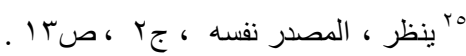

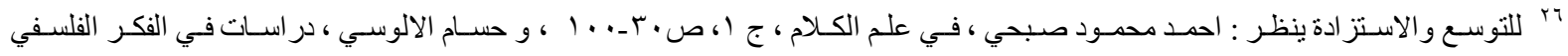

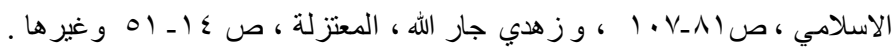

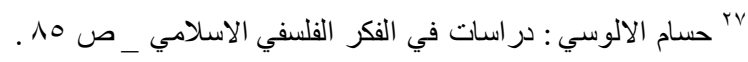

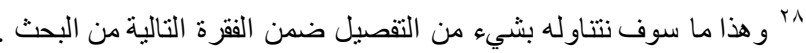

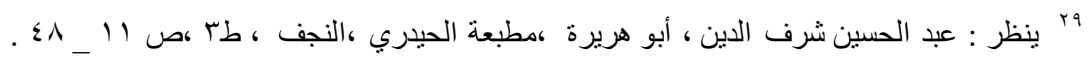

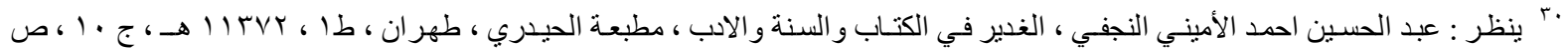
KTV_rOV

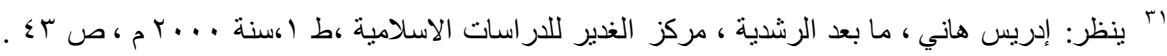

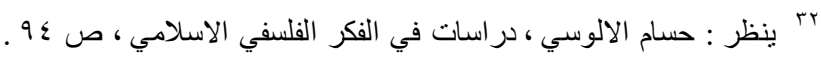

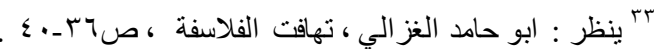

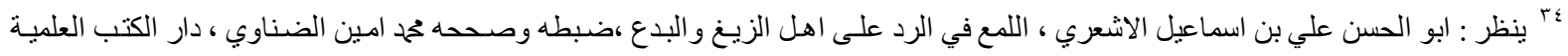

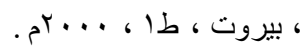

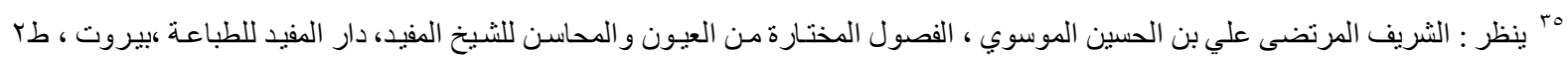
. م) 994 ،

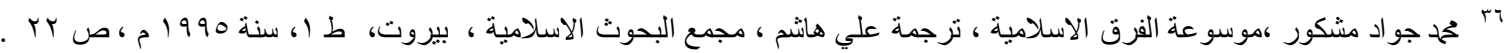
rr

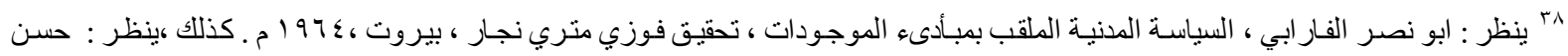

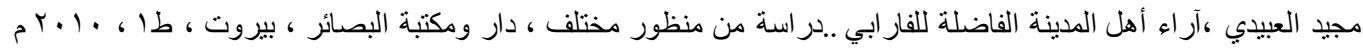

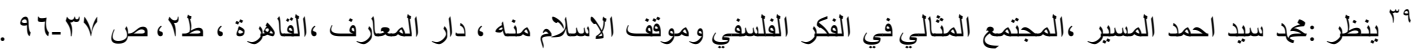
. 01 : النساء.

اء ينظر :مححم ضياء الدين الريس ،النظريات السياسية الاسلامية ،مكتبة، دار التراث ، القاهرة ، طV ، صع ب فما بعدها .

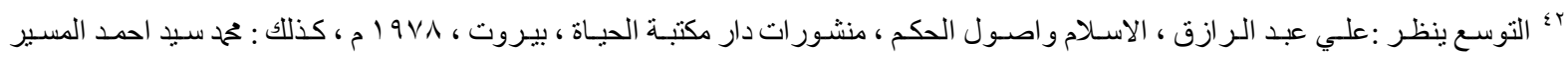

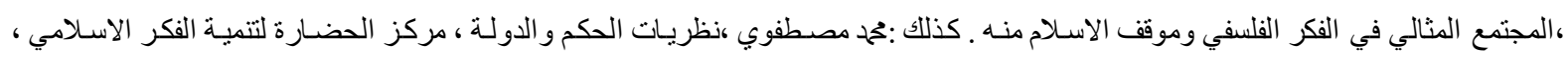


بيروت ، طץ ، كذلك :علي الفياض ، نظريات السلطة في الفكر السياسـي الثيعي المعاصر ، مركز الحضـارة لتتميـة الفكر الاسـلامي ، بيروت ، طب .

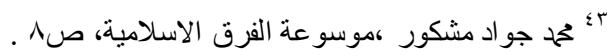

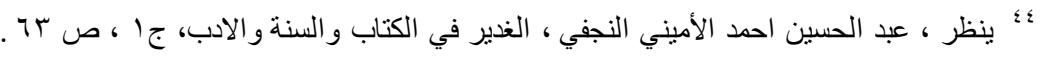

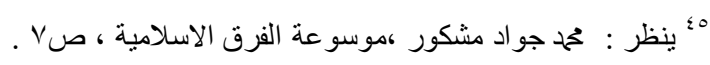

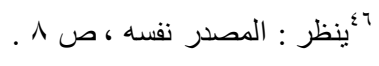

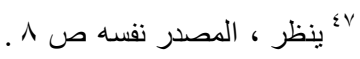

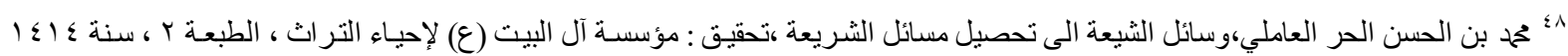

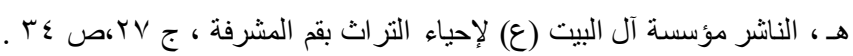

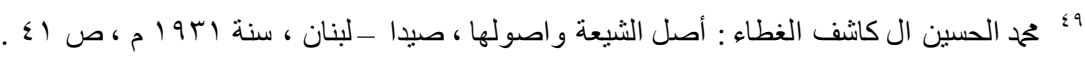

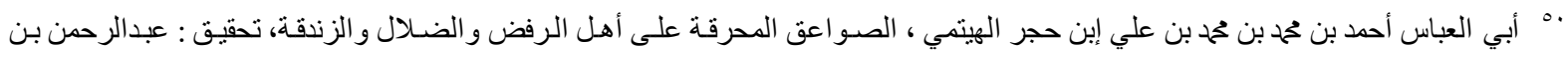

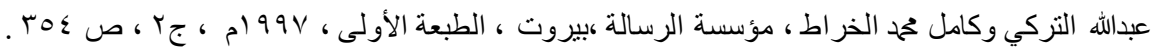

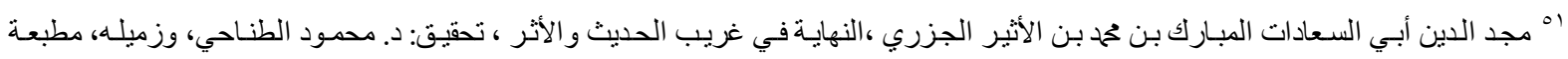

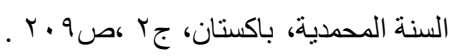

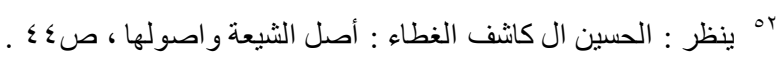

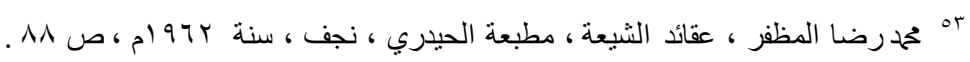

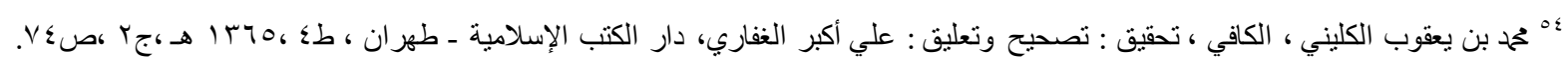

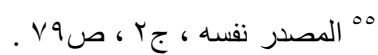

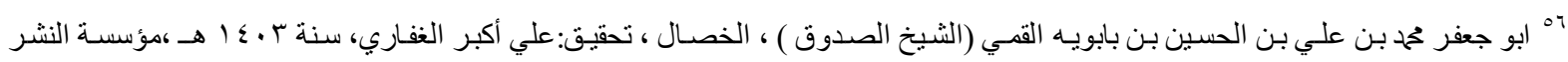

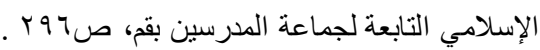

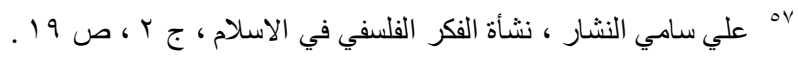

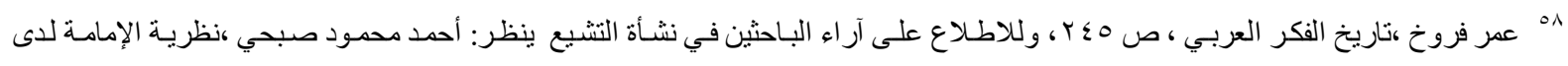

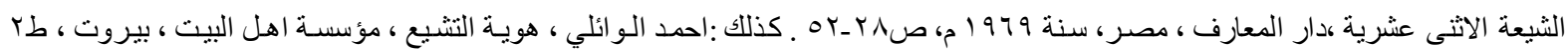

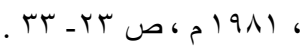

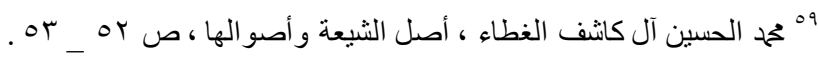
.

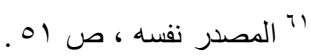

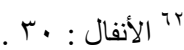

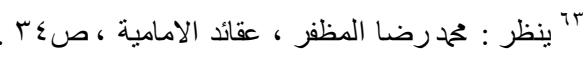

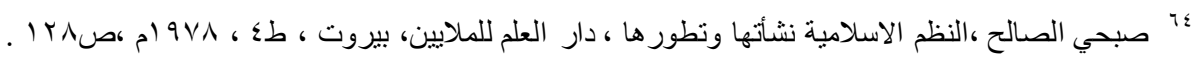

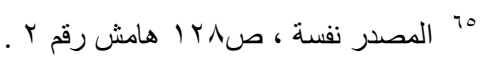
Tr

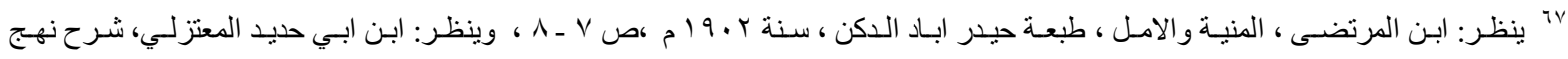

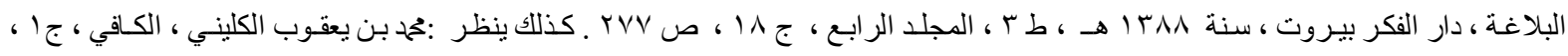
.9.-19 ص

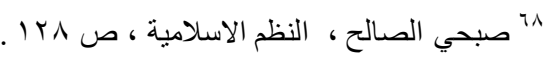
979

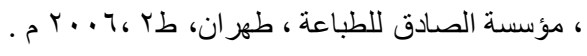




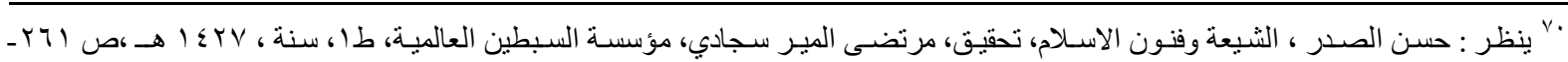

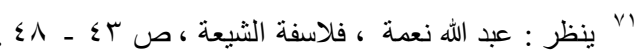

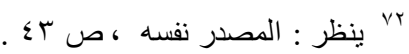

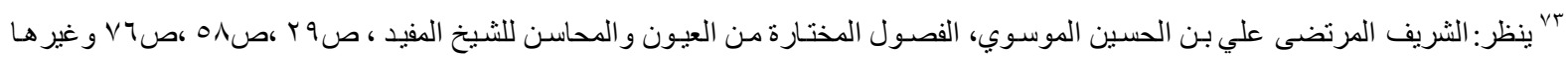

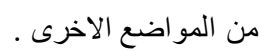

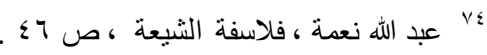

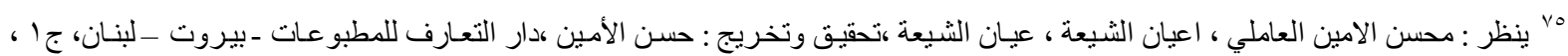

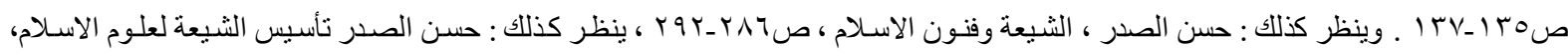

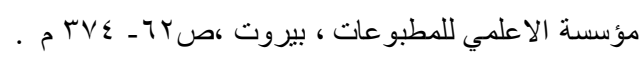

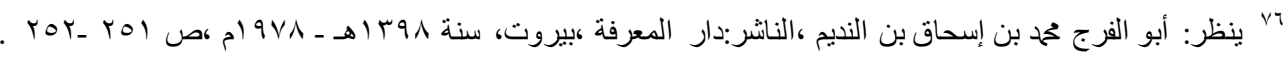

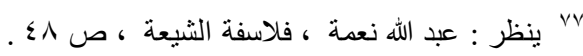

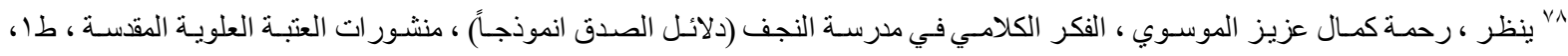

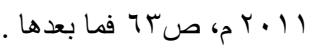

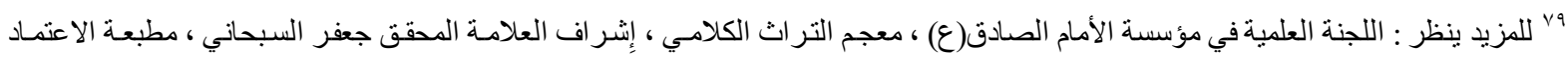
، قم ، طا ، بr أ ا هـ ، وهو كتاب ضخم يقع في خمسة مجلدات يتناول جميع المؤلفات الكلامية المخطوطة و المطبو عة للثيعة الامامية .

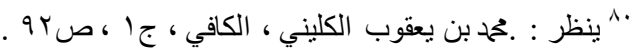

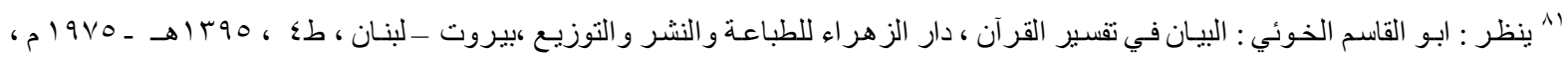

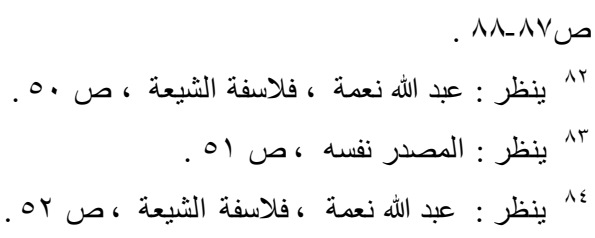

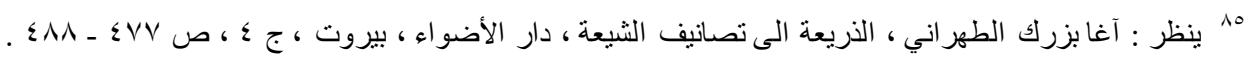

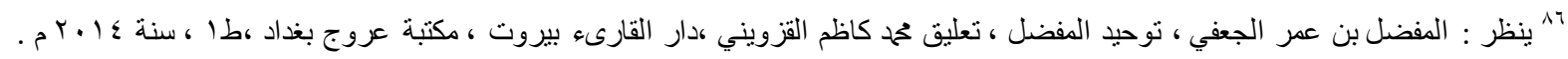

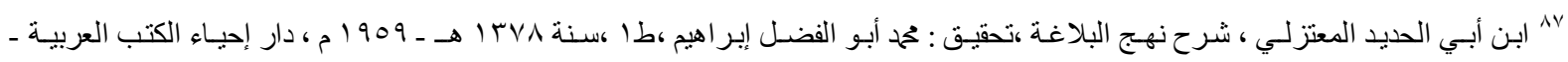

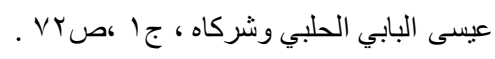

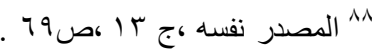

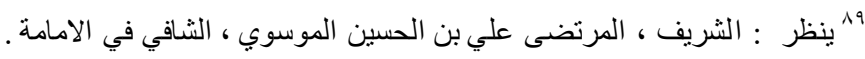

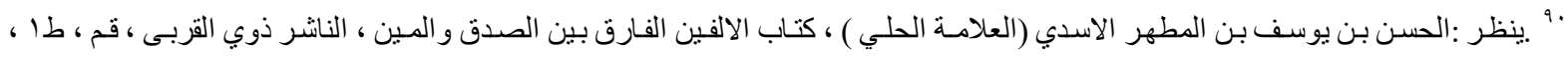
ه $\rightarrow$ ه $1 \leqslant 7$

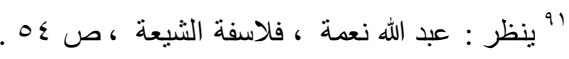
rو ينظر : الحسن بن يوسف بن المطهر الاسدي (العلامـة الحلي ) ، كثف المر اد في شرح تجريد الاعتقاد ، تحقيق : آيـة الله حسن ز اده الآملي،

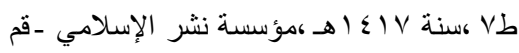

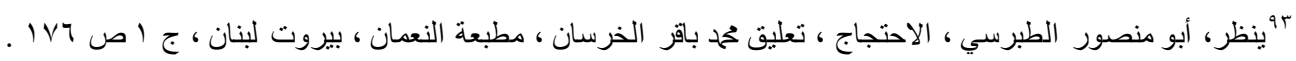

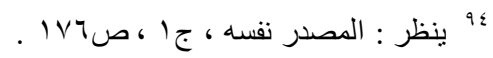

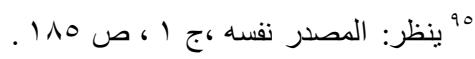

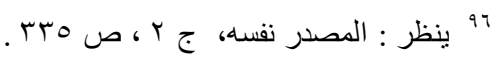

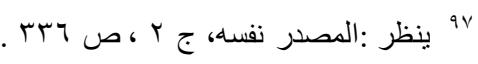

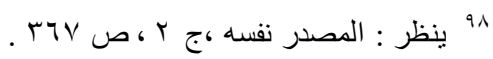




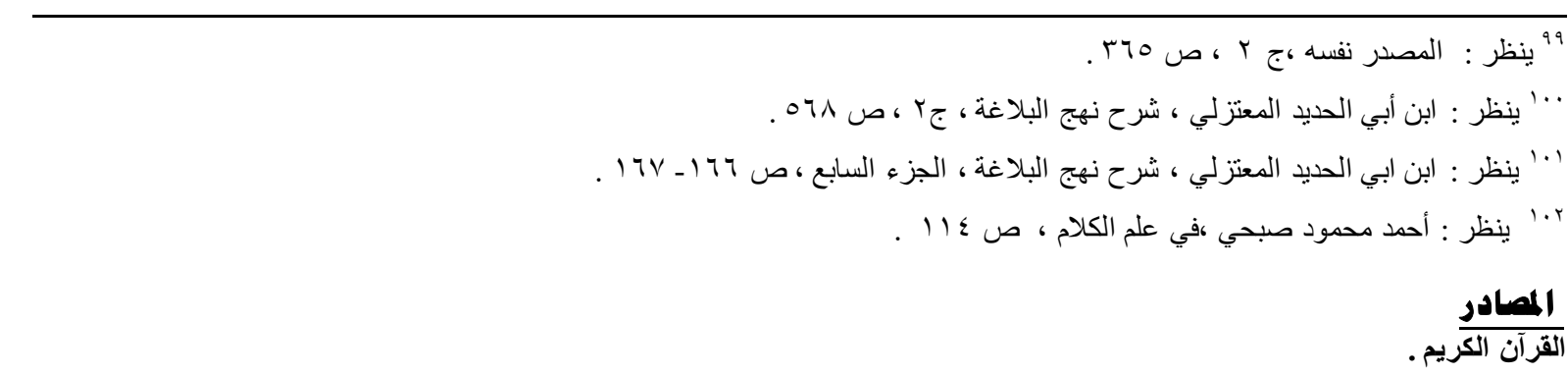

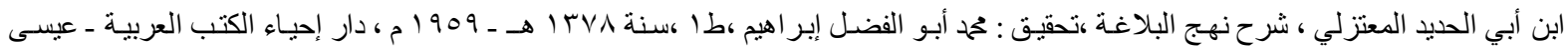
البابي الحلبي وشركاءه . ابن المرتضى ، المنية و الامل ، طبعة حيدر اباد الدكن ، سنة ب ـ 19 م . .

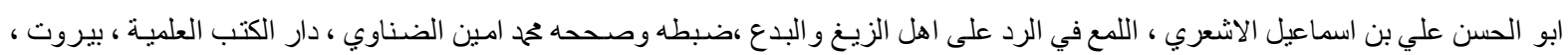

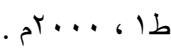

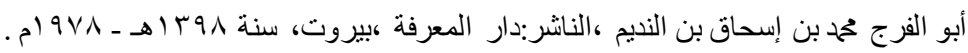

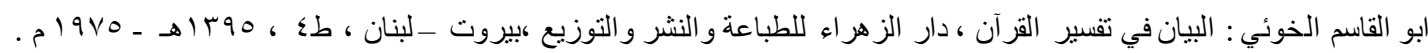

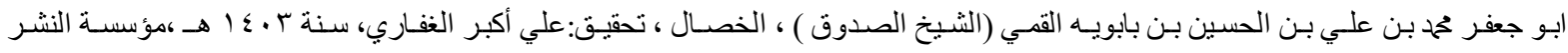

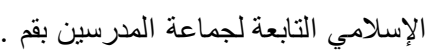

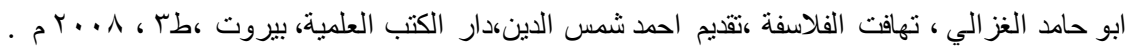

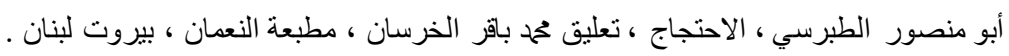

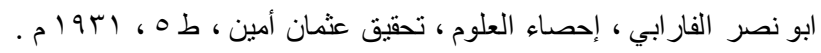

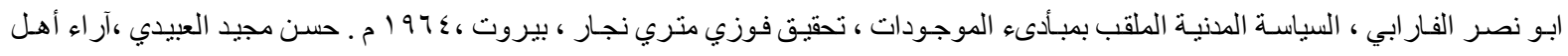

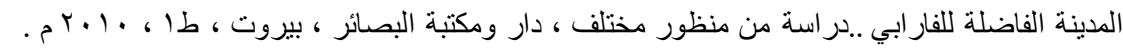

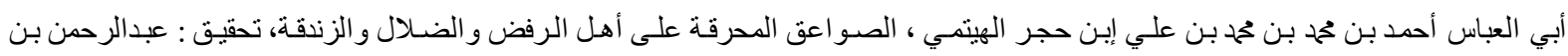

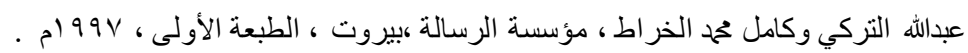

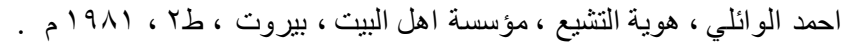

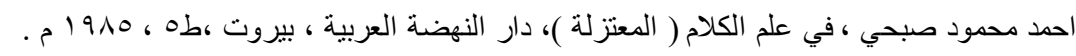

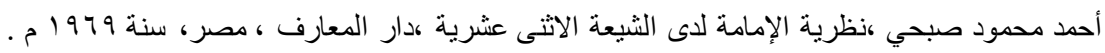

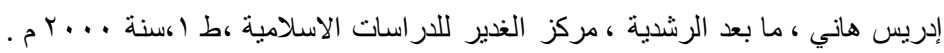

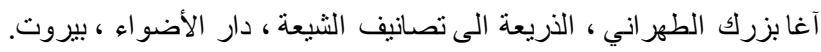

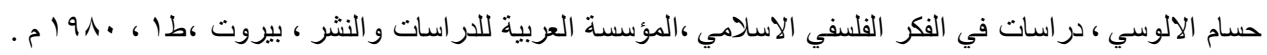

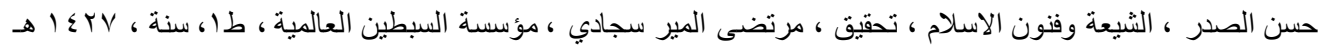

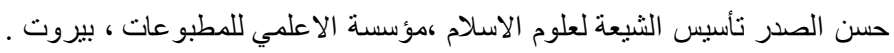

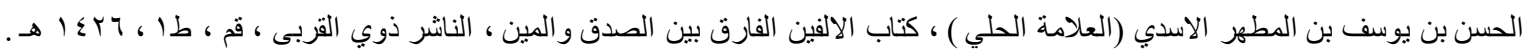

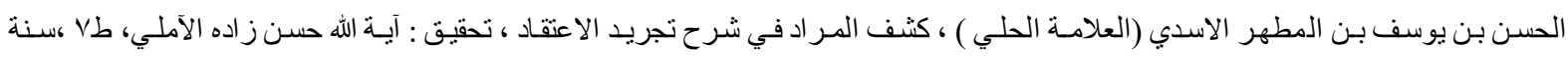

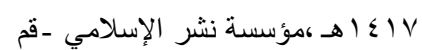

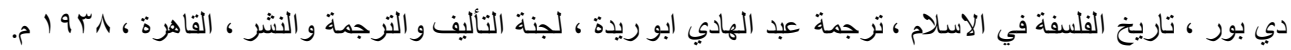

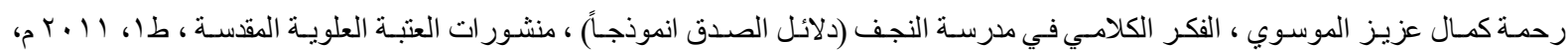
صrr فما بعدها .

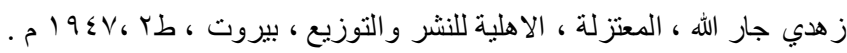

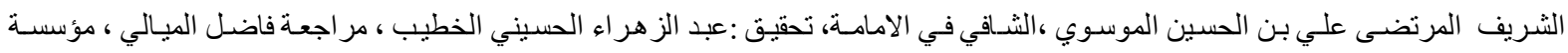

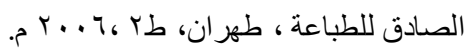


الثريف المرتضى علي بن الحسين الموسوي ، الفصول المختارة من العيون والمحاسن للثيخ المفيد، دار المفيد للطباعة ،بيروت ، طץ ، ب99 ام.

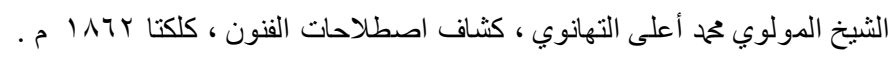

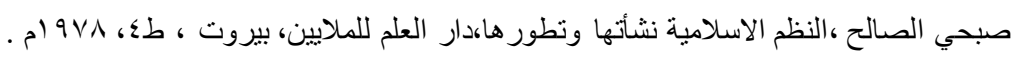

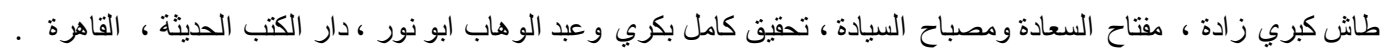

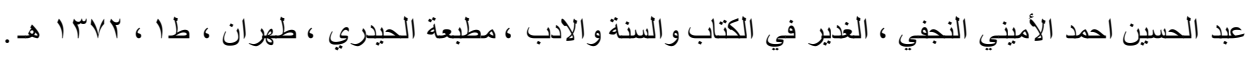

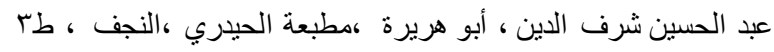
عبد الرحمن بن خلدون ، المقدمة ، مطبعة مصطفى محمد ، القاهرة .

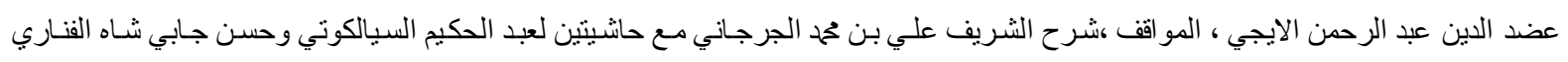

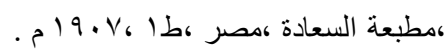

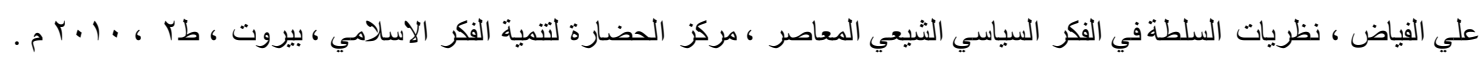

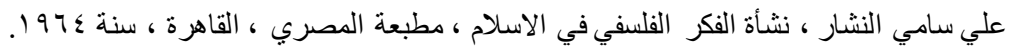

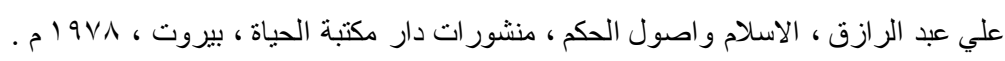

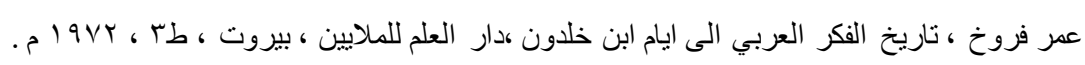

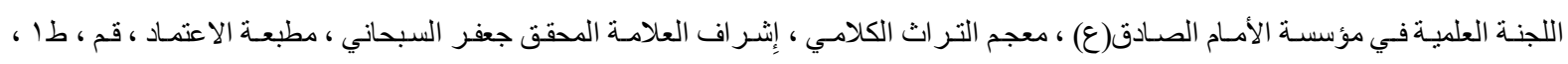
ه $\rightarrow$ ه $1 \leqslant r$

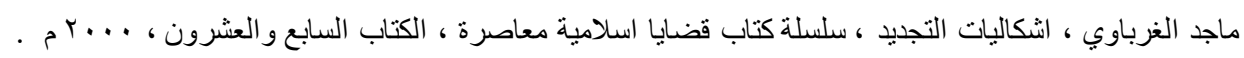

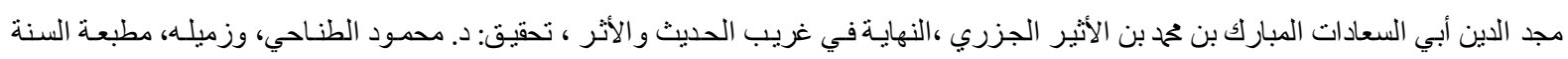
المحمدية، باكستان . محسن الامين العاملي ، اعيان الثيعة ، عيان الثيعة ،تحقيق وتخريج : حسن الأمين ،دار التعارف للمطبوعات ـ بيروت ـلبنان.

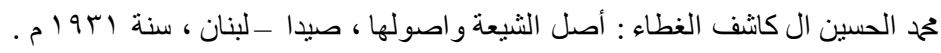

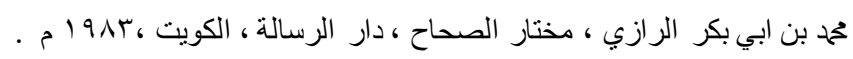

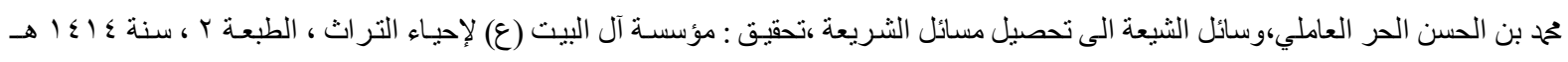

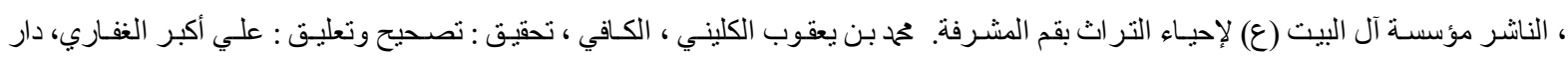

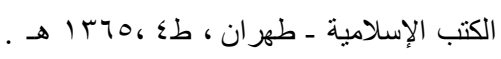

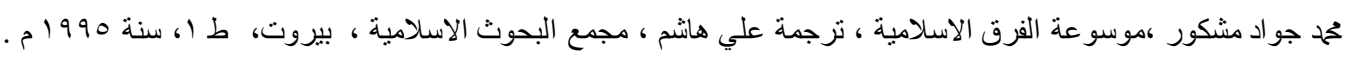

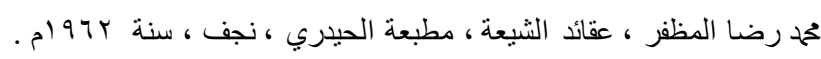

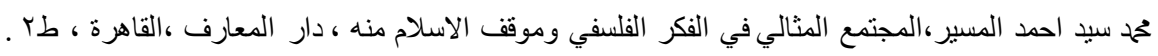

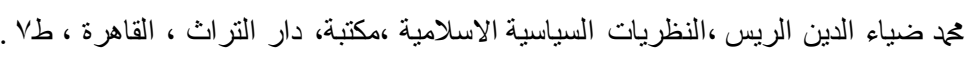

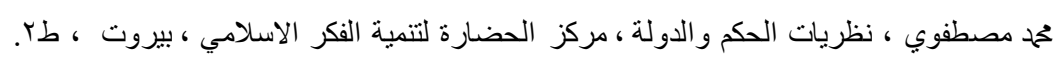

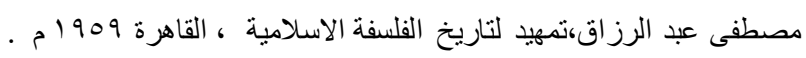

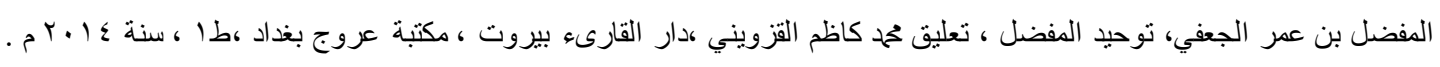

